\title{
EARNINGS BREAKS AND EARNINGS MANAGEMENT
}

\author{
by \\ Keng Kevin Ow Yong \\ Department of Business Administration \\ Duke University
}

Date:

Approved:

Katherine Schipper, Supervisor

Deborah DeMott

Shane Dikolli

Per Olsson

\begin{abstract}
Dissertation submitted in partial fulfillment of the requirements for the degree of Doctor of Philosophy in the department of Business Administration of Duke University
\end{abstract}




\section{$\underline{\text { ABSTRACT }}$ \\ EARNINGS BREAKS AND EARNINGS MANAGEMENT \\ by}

Keng Kevin Ow Yong

Department of Business Administration

Duke University

Date:

Approved:

Katherine Schipper, Supervisor

Deborah DeMott

Shane Dikolli

Per Olsson

An abstract of a dissertation submitted in partial fulfillment of the requirements for the degree of Doctor of Philosophy in the department of Business Administration of Duke University

2008 
Copyright by

Keng Kevin Ow Yong

2008 


\section{Abstract}

This paper examines the role of earnings management for firms that report at least three consecutive years of annual earnings increases (hereafter earnings string firms). Specifically, I examine how levels of earnings management change as earnings string firms approach the end of their earnings string patterns. My results show that earnings string firms engage in incomeincreasing earnings management consistent with an attempt to stretch these earnings string patterns. I also examine whether the cumulative effect of income-increasing earnings management activities during the earnings string period reduces the ability of these firms to continue reporting earnings increases. I do not find evidence to suggest that earnings string firms, on average, break their earnings string patterns because they ran out of accounting flexibility. However, there are two instances which the accumulated effect of income-increasing earnings management increases the likelihood of ending the earnings string. The two instances relate to firms which repeatedly engage in income-increasing earnings management throughout the earnings string period, and firms whose pre-managed earnings decline in the last year of the earnings string period. Finally, I show that firms that resume a subsequent series of reporting at least three consecutive years of annual earnings increases, on average, exhibit similar earnings management behavior. That is, these firms also increasingly resort to income-increasing earnings management toward the end of their second (or third) earnings strings. 


\section{Contents}

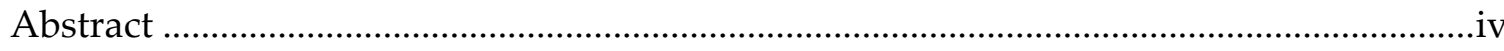

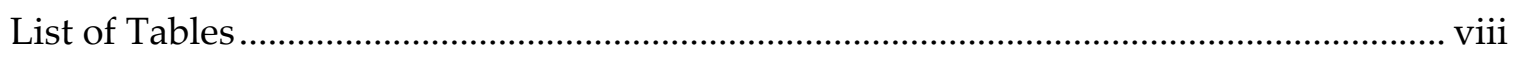

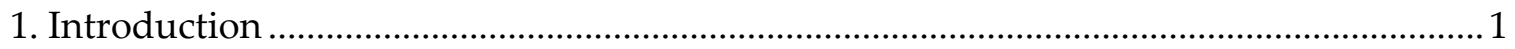

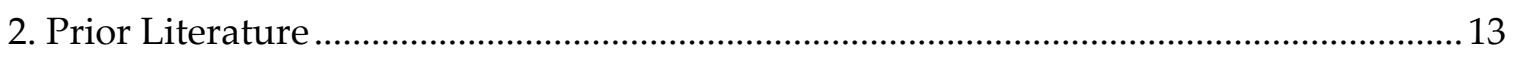

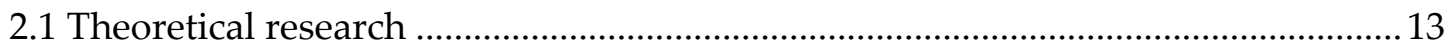

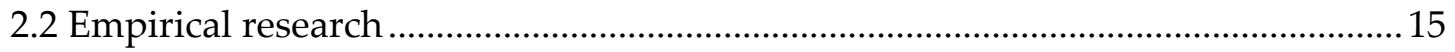

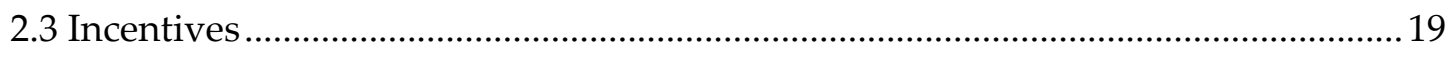

2.3.1 Desire to beat earnings targets .......................................................... 19

2.3.2 Valuation incentives ......................................................................... 20

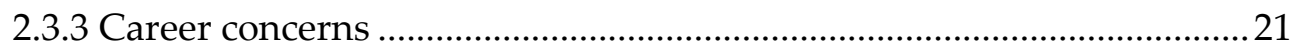

2.3.4. Compensation incentives .............................................................. 24

3 Motivation and Hypothesis Development ................................................................... 27

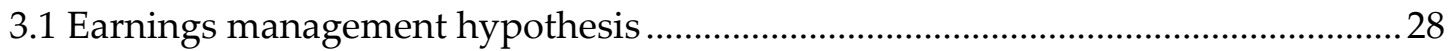

3.2 Earnings management constraint hypothesis ...................................................... 31

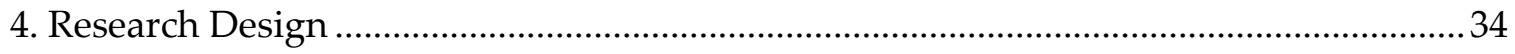

4.1 Earnings management measures........................................................................ 34

4.2 Earnings management constraint measures ....................................................... 37

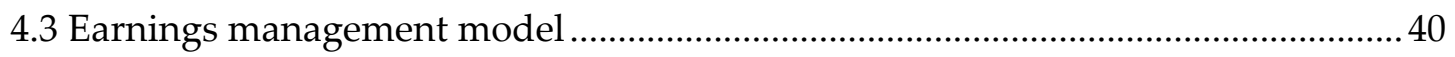

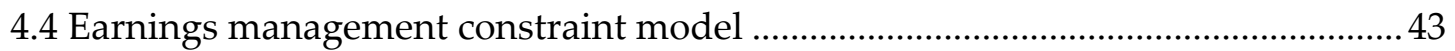




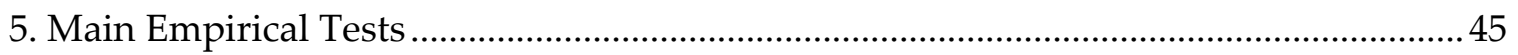

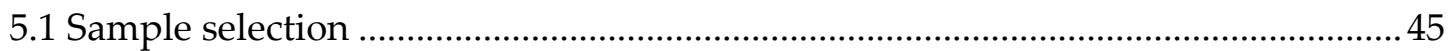

5.2 Descriptive statistics and correlations .................................................................. 49

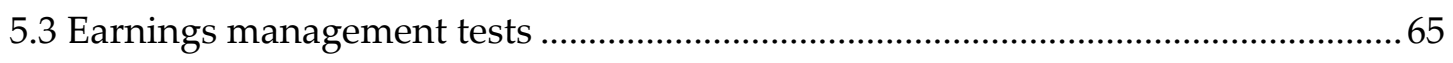

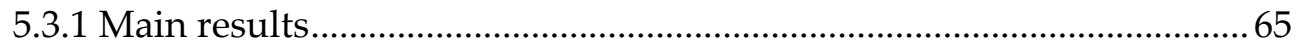

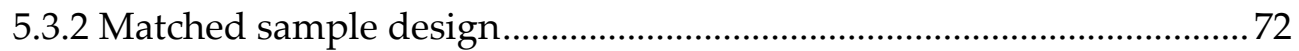

5.4 Earnings management constraint tests............................................................... 76

5.4.1 Portfolio analysis ........................................................................... 76

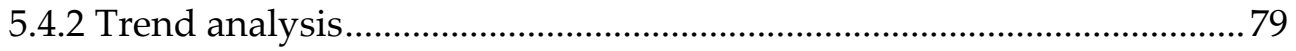

5.4.3 Logistic regression - Main results................................................... 84

5.4.4 Logistic regression - High EM firms ................................................ 87

5.4.5 Logistic regression - pre-managed earnings shortfall ........................... 91

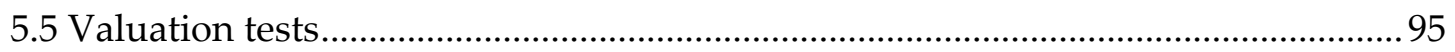

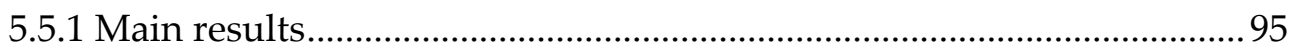

5.5.2 Interaction with earnings management ............................................ 100

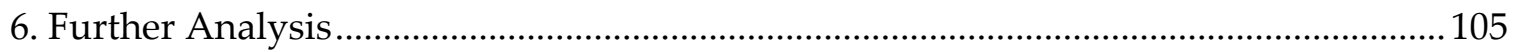

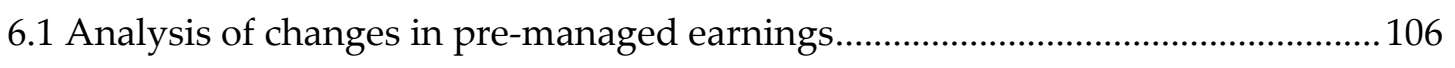

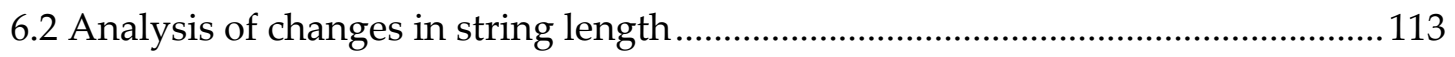

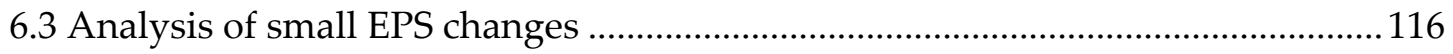

6.4 Analysis of firms' business uncertainty …......................................................... 121

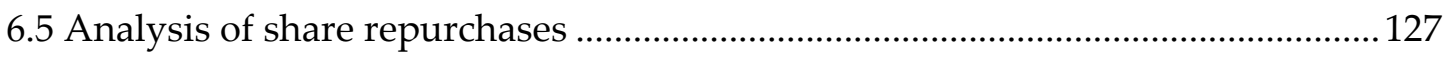




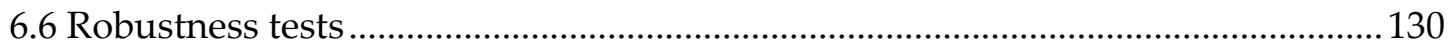

6.6.1 Control sample ............................................................................. 130

6.6.2 Benchmark firms with annual earnings increases.............................. 132

6.6.3 Within firm comparison ................................................................. 137

6.6.4 Long earnings string firms............................................................... 142

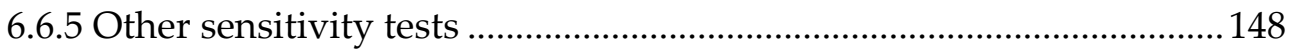

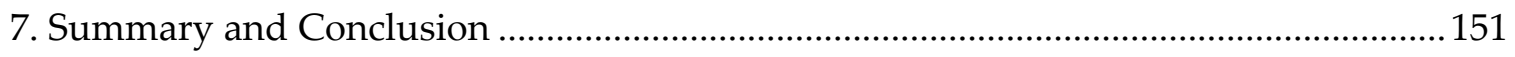

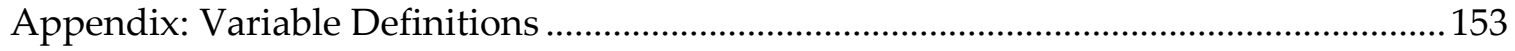

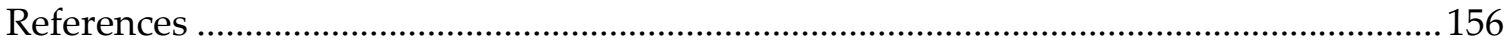

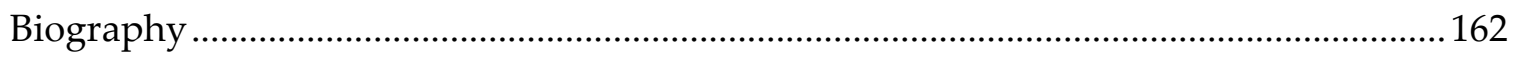




\section{List of Tables}

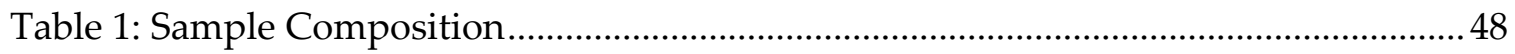

Table 2: Descriptive Statistics - Fundamentals ..................................................................... 51

Table 3: Descriptive Analysis - Changes in EPS................................................................. 56

Table 4: Time-series Analysis - Earnings Management Variables..........................................59

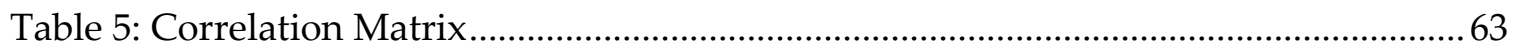

Table 6: Earnings Management Regressions - Main Results................................................6 69

Table 7: Earnings Management Regressions - Matched Sample Design ............................. 74

Table 8: Portfolio Analysis - Accounting Flexibility and Earnings Management..............78

Table 9: Trend Analysis - Accounting Flexibility and Earnings Management...................83

Table 10: Logistic Regression of Earnings Breaks - Main Results ....................................... 85

Table 11: Logistic Regression of Earnings Breaks - High EM Earnings String Firms....... 89

Table 12: Logistic Regression of Earnings Breaks - Pre-managed Earnings Shortfalls .... 93

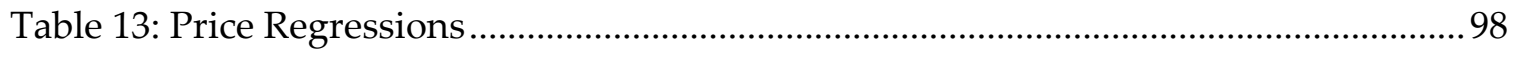

Table 14: Price Regressions - Impact of Income-increasing Earnings Management.......103

Table 15: Analysis of Pre-managed Earnings Changes ...................................................... 109

Table 16: Analysis of High/Low EM Earnings String Firms .............................................111

Table 17: Earnings Management Variables - Various String Length ...................................115

viii 
Table 18: Earnings Management Regressions - Small EPS Change

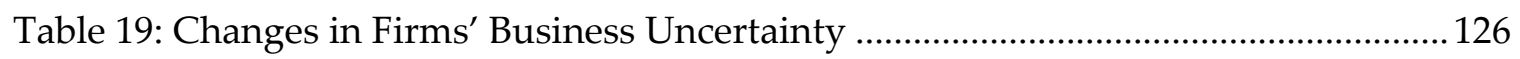

Table 20: Earnings String Firms - Share Repurchases ................................................ 129

Table 21: Earnings Management Regressions - Control Sample .................................... 131

Table 22: Earnings Management Regressions - Firms with Earnings Increases.............. 134

Table 23: Earnings Management Regressions - Within Firm Comparison ......................139

Table 24: Earnings Management Regressions - Long Earnings String Firms .................. 145 


\section{Introduction}

I examine the extent of earnings management and certain of its effects for firms reporting consecutive annual earnings increases for at least three years. These are firms that consistently report current year's earnings that are higher than last year's earnings for a period ranging from three years to as long as 43 years (hereafter the earnings string). The mean (median) length of these earnings strings is 4.6 years (4 years). I investigate whether, when and to what extent these firms engage in earnings management to meet their earnings targets. My analysis is motivated in part by Dechow and Skinner (2000) who suggest a need to examine the earnings management behavior of these firms. ${ }^{1}$

A central finding in the earnings management literature is that managers appear to manage earnings to avoid reporting an earnings decrease (Burgstahler and Dichev 1997; Degeorge, Patel and Zeckhauser 1999). For firms that consistently report increasing earnings, a question of interest to market participants as well as to regulators is how much of the reported earnings is "managed" and how much of it is "real". This question is not easily answered because theory and prior research do not provide a basis for predicting any specific pattern of earnings management during a period of uninterrupted earnings growth. That is, managers may or may

\footnotetext{
${ }^{1}$ Dechow and Skinner (2000) propose that academics' research efforts should focus more on capital market incentives for earnings management. They assert that stock market incentives to manage earnings to maintain or improve firm valuations have increased over the years. They believe that understanding management's incentives is the key to understanding their desire to engage in earnings management; in particular, they conjecture that managers with strong incentives to beat earnings benchmarks are potentially more likely to engage in earnings management.
} 
not engage in income-increasing earnings management depending on firm-specific fundamentals as well as industry conditions.

I examine the end of the earnings string period (i.e., the three years of the earnings string before it breaks). I investigate whether managers of firms that repeatedly report annual earnings increases appear to take actions to stretch the earnings string beyond what fundamentals support via income-increasing earnings management. Evidence that managers of earnings string firms resort to income-increasing earnings management to delay the break in their earnings string patterns (and the consequent bad news associated with reporting an earnings decrease) would be of interest to investors in analyzing the perceived growth in these stocks as well as to regulators and others who are concerned about earnings quality.

My first hypothesis is that managers of earnings string firms engage in income-increasing earnings management to extend their earnings string periods. In formulating this hypothesis, I make two assumptions about the end of the earnings string period. First, I assume that managers of earnings string firms are consistently motivated to report earnings increases. Second, I assume that at least some of these firms experience increasing difficulty reporting an earnings increase during this period. To the extent that these assumptions are not true, they bias against the results in my tests.

With regard to the first assumption, prior research provides an economic basis for the wish to extend a pattern of increasing earnings as long as possible. Barth, Elliot and Finn (1999) find that firms that report increasing earnings year after year are rewarded with a valuation 
premium in the form of a higher price-earnings multiple than their peer firms, and that this valuation premium disappears once the earnings pattern is broken. I assume that this valuation premium provides an incentive for managers to keep reporting increasing earnings. My valuation tests confirm the presence of a valuation premium for firms reporting consecutive annual earnings increases and its disappearance when the earnings string pattern is broken, consistent with Barth et al.'s (1999) findings.

With regard to the second assumption, prior research finds that managers of earnings string firms can predict approximately when the earnings strings might break. Specifically, Ke, Huddart and Petroni (2003) find that managers of earnings string firms sell their stock up to two years in advance of an earnings break consistent with an ability to anticipate when the earnings string will break. This suggests that the conditions leading to the break in the earnings string pattern, on average, are at least partially attributable to events that managers anticipate. Based on Ke et al. (2003), I expect to find evidence of income-increasing earnings management in the last two years preceding the break in the earnings string pattern.

My empirical tests find strong evidence in support of income-increasing earnings management in the last year prior to the earnings break and mixed evidence of income-increasing earnings management two years before the earnings break. The results suggest that managers, on average, appear to manipulate earnings upwards to obtain at least an additional one or two years of earnings increase (or equivalently, to delay the reporting of an earnings decrease by one or two years). 
The second part of my paper builds on this finding as well as prior research that shows a pattern of income-increasing earnings management eventually reduces managers' ability to manage future earnings (Barton and Simko 2002). That is, even though managers appear to be able to extend an earnings string, it seems that these income-increasing earnings management activities are not sustainable beyond one to two years, on average; eventually the series of consecutive annual earnings increases ends. I investigate whether earnings string firms have run out of accounting flexibility to manage earnings upwards and thus their earnings string patterns end.

Barton and Simko (2002) assert that there is an upper bound as to how much managers can manipulate earnings upwards over time if they wish to remain GAAP-compliant. That is, GAAP rules allow some level of accounting flexibility (or discretion) that managers can use to artificially boost earnings, beyond which managers will violate GAAP. Furthermore, incomeincreasing earnings management in one period reduces managers' ability to manage earnings upwards in subsequent years. ${ }^{2}$ Thus, the manager who has managed earnings upwards the year before has less accounting flexibility to manage earnings upwards in the current year.

Following Barton and Simko (2002), I use the ratio of net operating assets divided by sales (NOA ratio) and the ratio of working capital assets divided by sales (WCNOA ratio) as my measures of accounting flexibility. Barton and Simko (2002) propose and validate these ratios as

${ }^{2}$ For example, a manager who engages in income-increasing earnings management by extending the useful lives of fixed assets (so as to reduce annual depreciation charges and boost net income) in one year has less flexibility to extend again the useful lives of the same fixed assets the next year. 
empirical measures of accounting flexibility (which is not directly observed). They observe that earnings management activities which increase current earnings will also increase net assets as a result of the articulation between the income statement and the balance sheet. ${ }^{3}$ Because balance sheet numbers are carried forward to the next period, the asset-increasing effect of earnings management stays on the balance sheet unless it is reversed out or realized as cash. The NOA (WCNOA) ratio captures the level of net operating assets (working capital) needed to support sales. ${ }^{4}$ The implication with regard to firms that report a steady path of rising earnings is as follows. If these firms have been manipulating earnings upwards, there should be an over-time decrease in accounting flexibility as a result of these earnings management activities. It is an empirical question as to whether earnings string firms break their increasing earnings patterns because they run out of accounting flexibility to manage earnings upwards. This is the basis of my second hypothesis, formalized as follows: the break in an earnings string is associated with reduced accounting flexibility to manage earnings upwards.

I find mixed evidence in support of this hypothesis when I use the WCNOA ratio as my proxy for accounting flexibility for my full earnings string sample. However, for some earnings

\footnotetext{
${ }^{3}$ As an example, if managers under-provide for bad debts, the increase in income in the current year is accompanied by a corresponding balance sheet increase in net accounts receivable. The accounts receivable will be higher by the under-provision for bad debts in every subsequent year until managers increase the provision (or write off the bad debt), or collect the amount owed.

4 Thus, a NOA ratio of 2.0 indicates that the firm requires $\$ 2$ net operating assets for every dollar of sales. An increase in this ratio could indicate reduced asset productivity (i.e., the assets are not generating the same level of sales dollars as before) or that the firm's balance sheet numbers are inflated as a result of incomeincreasing earnings management.
} 
string firms within my full sample, I find consistent evidence that the eventual break in the earnings string pattern is attributable to decreased accounting flexibility based on tests using WCNOA ratios. ${ }^{5} \mathrm{I}$ do not find evidence in support of my hypothesis in tests using NOA ratios.

My earnings string sample consists 6,130 Compustat firms excluding banks and utilities from 1952-2005 that report at least three consecutive years of annual earnings increases. A firm may report several periods of consecutive annual earnings increases. I rerun my tests separately for firms that report a second (or third) earnings string. My benchmark sample consists of all non-earnings string firm-year observations excluding banks and utilities in the Compustat population between 1951-2006.

To test my hypothesis that earnings string firms engage in income-increasing earnings management in the last two years of their earnings string period, I run an event-study regression model with my measure of earnings management as the dependent variable. Firm-year observations are arranged in event time in relation to the year of the earnings break. ${ }^{6} \mathrm{I}$ use the modified Jones model's discretionary accruals (Jones 1991; Dechow, Sloan and Sweeney 1995) as

\footnotetext{
${ }^{5}$ These are earnings string firms that have been shown to have engaged consistently in income-increasing earnings management during the earnings string period. I discuss my analysis of these firms in more detail in sections 5.4.4 and 5.5.2.

${ }^{6}$ I code firm-year observations one year before the earnings string breaks (or alternatively, the last year of the earnings string period) as 1 and 0 otherwise using the indicator variable PREBREAK1. Likewise, PREBREAK2 (PREBREAK3) denotes firm-year observations two (three) years before the earnings string breaks. BEGSTRING denotes firm-year observations within the earnings string period that precede the break by more than three years. Every firm-year observation that is part of the earnings string period has one indicator variable $=1$ and the rest=0. The benchmark sample's firm-year observations (not part of the earnings string) have all indicator variables coded as zero.
} 
my measure of earnings management. The modified Jones model attempts to parse accruals into "discretionary" and "nondiscretionary" components. The discretionary component, the residual from regressing total accruals on accounting fundamentals, is used by accounting researchers to measure earnings management.

I test whether there is evidence of income-increasing earnings management in each of the three years prior to the break in the earnings pattern (i.e., PREBREAK1, PREBREAK2 and PREBREAK3) and the earlier years in the earnings string period (BEGSTRING). I expect to find a positive coefficient for these indicator variables if earnings string firms systematically engage in income-increasing earnings management relative to the benchmark sample firms. My first hypothesis predicts a positive coefficient for both PREBREAK1 and PREBREAK2 and makes no prediction for PREBREAK3 and BEGSTRING.

I find that earnings string firms systematically engage in income-increasing earnings management in the last year of their earnings string patterns compared to the benchmark sample (non-earnings string firms). Discretionary accruals in the year preceding the earnings break (year $t-1$ ) for the earnings string firms that report their first earnings string are 2.4 percent of total assets higher (t-statistic: 14.23, $\mathrm{p}<0.001)$ than for the average non-earnings string firm, indicating evidence of income-increasing earnings management in the last year of the earnings string. This finding is robust to using alternative specifications (Fama-MacBeth regressions, cluster standard error approach, fixed effects model), controlling for performance in the discretionary accruals measures, restricting the benchmark sample to non-earnings string firms that report earnings 
increases, performing a within-firm comparison and a matched sample approach, and excluding loss firms.

I extend my earnings management tests to the second (third) earnings string sample. I find a positive coefficient for PREBREAK1 in both samples. Specifically, firms that report a second (third) earnings string have discretionary accruals that are 1.9 percent (1.2 percent) higher than the average non-earnings string firm, significant at the 0.01 level. It thus appears that the earnings management behavior observed in firms reporting their initial series of annual earnings increases recurs when the same firms report a second (third) series of annual earnings increases. These results suggest that managers exhibit recurring tendencies to bias earnings upward when faced with the possibility of declining earnings.

I find mixed evidence of income-increasing earnings management in the second-last year of the earnings string period. Compared to the benchmark sample, discretionary accruals in the second year preceding the earnings break (year $t$-2) for the earnings string firms that report their first earnings strings are 0.9 percent of total assets higher (t-statistic: $5.35, \mathrm{p}<0.001)$. However, the results are mixed and sensitive to changes in specifications. I also do not find evidence of incomeincreasing earnings management in year $t-2$ when I extend my tests to the second (third) earnings string samples. I interpret these results as providing little evidence of income-increasing earnings management two years prior to the break in an earnings string pattern. This might be because earnings string firms have less need to engage in income-increasing earnings management in year $t-2$ than in year $t-1$, consistent with my assumption that firms experience increasing 
difficulty maintaining their increasing earnings patterns as they reach the end of their earnings strings.

With regard to my second hypothesis, I first perform two construct validity tests of the NOA and WCNOA ratios. If these measures are good proxies for accounting flexibility, I expect to find a negative contemporaneous relation between cumulative discretionary accruals and accounting flexibility. I find evidence to suggest that the NOA and WCNOA ratios are reasonably good proxies for accounting flexibility. Specifically, in cross-sectional tests, I find that firms that belong to the highest quintile of NOA ratios and WCNOA ratios (i.e., firms with the least accounting flexibility to manipulate earnings upwards) also report the highest signed levels of accumulated discretionary accruals. This result indicates that firms that engaged in more incomeincreasing earnings management in previous years presently have less accounting flexibility (i.e. these firms are constrained in their earnings management activities). ${ }^{7}$ My second test assesses the overtime changes in the earnings management and earnings management constraint variables for my earnings string sample. I expect to find these measures move in the same direction if the NOA and WCNOA ratios capture the accumulated effects of prior years' income-increasing earning management. My trend regression results confirm my predictions. Both the earnings management and earnings management constraint measures trend upwards, indicating that as firms engage in more income-increasing earnings management, they also experience decreased

\footnotetext{
7 Throughout this paper, I use the term accounting flexibility interchangeably with earnings management constraint in the following manner. A firm with decreased accounting flexibility is also described as a firm that is increasingly constrained from engaging in income-increasing earnings management and vice versa.
} 
accounting flexibility (i.e., increased earnings management constraint). All trend coefficients are significant at the 0.01 level.

To test the hypothesis that managers are constrained from engaging in income-increasing earnings management when the earnings string pattern ends, I run a logistic regression modeling the likelihood of breaking an earnings pattern as a function of accounting flexibility. The dependent variable is BREAK = 1 for firm-year observations at the break of the earnings string and 0 for firm-year observations within the earnings string period. I test whether NOA and WCNOA ratios, measured using beginning year's values in the year of the earnings string break, are associated with the likelihood of breaking an earnings string. I expect to find a positive coefficient for the NOA (WCNOA) ratio if the likelihood of breaking an earnings string is greater for firms with higher NOA (WCNOA) ratios. I interpret a positive coefficient for the NOA (WCNOA) ratio in this test to imply that earnings string firms are constrained by their balance sheet numbers and are unable to bias earnings upwards as before.

I do not find evidence to suggest, on average, that the likelihood of breaking an earnings string is associated with reduced accounting flexibility for my earnings string samples. The exception is the first earnings string sample where I find a positive association between BREAK and the WCNOA ratio. However, I also find evidence that there are two conditions within my earnings string sample when the likelihood of breaking an earnings string is attributable to reduced accounting flexibility. Specifically, I find positive results for this test (using the WCNOA ratios) for a subsample of earnings string firms that engaged in income-increasing earnings 
management at least half the years during their respective earnings string periods, and for a subsample of earnings string firms whose pre-managed earnings in the last year of the earnings string period is lower than in the previous year. I interpret these results to suggest that earnings string firms which my earnings management tests detect as having engaged in income-increasing earnings management during the earnings string period appear to be the firms most constrained by the reduced accounting flexibility in their working capital accruals as they reach the end of their earnings string. Consequently, for this sample, managers' inability to use working capital accruals to manage earnings upwards partially explains the break in their earnings string patterns.

My paper extends existing research on earnings management in several ways. First, my findings provide a time-series analysis of earnings management in a sample of firms that consistently report earnings increases for a number of years. I contribute to the stream of research on the earnings management behavior of these firms (Ghosh, Gu and Jain 2005; Myers, Myers and Skinner 2007) by documenting consistent evidence of income-increasing earnings management in the last year of the earnings string period. This finding adds to existing research that establishes circumstances associated with earnings management. ${ }^{8}$

\footnotetext{
8 The earnings management literature has identified circumstances that could cause managers to manipulate earnings. This includes findings that managers engage in income-increasing earnings management prior to initial public offerings (Teoh, Welch and Wong 1998a) and seasoned equity offerings (Teoh, Welch and Wong 1998b), before stock options exercise (Bartov and Mohanram 2004; Cheng and Warfield 2005; Bergstresser and Philippon 2006) and stock-financed acquisitions (Erickson and Wang 1999), and to avoid violating loan covenants (Watts and Zimmerman 1990).
} 
Second, my findings contribute to research on accounting flexibility. Barton and Simko (2002) hypothesize that one reason why some firms miss earnings expectations even by a small amount is that they have used up their accounting flexibility to manage earnings upwards. They report evidence that higher net operating asset ratios (i.e., reduced accounting flexibility) are associated with increased likelihood of missing expectations. I contribute to this stream of research by examining the role of accounting flexibility when firms break their earnings string pattern after having consistently reported annual earnings increases for an extended period. Consistent with the notion that firms that engaged in income-increasing earnings management in prior years have reduced accounting flexibility to manage earnings upwards, I find a positive association between the likelihood of breaking an earnings string and reduced accounting flexibility for firms that have been shown to have engaged in income-increasing earnings management during the earnings string period.

The rest of my dissertation is organized as follows. Chapter 2 reviews the related prior research. Chapter 3 motivates and develops my hypotheses. Chapter 4 explains my models and describes my empirical measures. Chapter 5 describes my sample and presents the main results from my tests. Chapter 6 details further analysis and sensitivity tests. Chapter 7 concludes and discusses the implications of my results. 


\section{Prior Literature}

\subsection{Theoretical research}

Several theoretical papers model the relation between earnings management and accounting performance. These papers provide insights as to conditions that would lead managers to manage earnings upwards. Degeroge, Patel and Zeckhauser (1999) suggest that managers would manipulate earnings upwards to delay the reporting of an earnings decrease. Lee, Li and Yue (2006) suggest that managers have higher incentives to manipulate earnings upwards the higher the level of accounting performance. I discuss both papers in more detail as follows.

Degeorge et al. (1999) develop a two-period model with last period's earnings as the earnings threshold. In their model, managers can manipulate reported earnings in period one by choosing an amount $M_{1}$ to add to earnings. However, doing so reduces earnings by $M_{1}$ in the next period. The authors show that when the second period's prospects are uncertain, managers will engage in income-increasing earnings management in the current period and thus meet or beat earnings benchmarks in this period at the expense of next period's earnings.

The authors do not directly address the issue of earnings string firms whose managers seek to extend an existing pattern of earnings increases. However, I view their two-period model as reflecting a scenario where managers who foresee the end of an earnings string period contemplate whether it is worthwhile to manipulate current period earnings by engaging in 
income-increasing earnings management. For example, if managers believe the unmanaged earnings string will break, Degeorge et al.'s (1999) model predicts that managers will have incentives to shift income from future periods to secure another year of reporting increasing earnings because they assume that managers are rewarded by the market for meeting or beating earnings thresholds.

Lee, $\mathrm{Li}$ and Yue (2006) examine the relation between earnings management and firm performance and ask what drives the positive association between earnings management and accounting performance. In their model, managers manage earnings to influence stock prices. Their model predicts that higher performance (i.e., higher reported earnings) increases managerial motivation to overstate earnings. The intuition of their model is that managers have greater incentives to overstate earnings when reported earnings are high because the sensitivity of the price response to earnings increases with the magnitude of reported earnings.

Lee et al. (2006) model the cost of earnings management as an increasing convex function. That is, it is more costly for managers with high reported earnings to maintain the same proportion of managed earnings. The market rationally expects this, which justifies the higher price responsiveness to higher reported earnings. The higher price responsiveness in turn induces managers to bias earnings upwards. There is a unique revealing equilibrium in their model whereby the amount of managed earnings increases less than proportionally with reported earnings. The authors suggest their model provides a rational explanation for why the amount of managed earnings should be positively related to a firm's performance and growth. 
Lee et al. (2006) do not directly discuss whether earnings string firms will engage in income-increasing earnings management. ${ }^{1}$ However reported earnings are, by definition, high at the end of an earnings string period so managers that have already reported rising earnings for a period of time have incentives to use income-increasing earnings management, if necessary, to continue to report higher earnings. In other words, applying their model to the end of an earnings string pattern (when reported earnings have been increasing) yields the prediction that managers of earnings string firms have incentives to manage earnings upwards even when the earnings string pattern is increasingly unsustainable. ${ }^{2}$

\subsection{Empirical research}

Related empirical research that examines the earnings management behavior of firms with a consecutive series of earnings increases provides instances where managers of earnings string firms resort to earnings management during the earnings string period. I contribute to this stream of research by documenting consistent evidence of income-increasing earnings management in the last year of the earnings string period. My tests thus provide evidence that

\footnotetext{
${ }^{1}$ Another caveat in applying Lee et al. (2006) to my setting is that their model does not address the intertemporal nature of earnings management (i.e., the reversal of accruals). Notwithstanding this limitation, the main insight I draw from their model is that managers of earnings string firms face increasing incentives to manage earnings with each successive year of beating earnings benchmarks so as to maintain high stock prices.

${ }^{2}$ My empirical tests, discussed later, support this assertion.
} 
managers of earnings string firms use income-increasing earnings management to extend their earnings strings. Two other papers that examine different aspects of the earnings management behavior of earnings string firms are Myers, Myers and Skinner (2007) and Ghosh, Gu and Jain (2005).

Myers et al. (2007) examine 746 firms which report at least 20 consecutive seasonallyadjusted non-decreases in quarterly earnings per share between 1963-2004. They argue that it is unlikely that so many firms can report such consistent earnings growth over an extended period based on economic performance. Their research question asks whether managers of these firms exercise financial reporting discretion to sustain and extend their firms' earnings strings. They find evidence of income-smoothing behavior by showing an unusually strong negative correlation between these firms' cash flows and accounting accruals, which they interpret as evidence that accruals are used to smooth reported earnings. They also show that managers exercise discretion over the reporting of special items, time their firms' stock repurchases and adjust their effective tax rates (ETRs) to increase earnings per share when overall earnings decline. They conclude that there is evidence of income-smoothing, on average, when firms report steadily rising earnings.

Myers et al.'s (2007) tests are association tests designed to document, on average, that earnings string firms engage in income-smoothing. Their results do not address when during an earnings string smoothing occurs. Neither do they analyze whether smoothing extends the earnings string periods of these firms. Instead, their tests are designed to find evidence that 
earnings string firms manipulate earnings in a way that is consistent with income smoothing. For example, they use regression tests to show that income smoothing via ETR is more pronounced for earnings string firms than other firms.

In contrast, my aim is to assess whether firms manage earnings upwards to delay a break in an earnings string pattern. Thus, my results extend Myers et al.'s (2007) income-smoothing results, by providing evidence of income-increasing earnings management in earnings string firms before the break in the earnings string pattern. ${ }^{3}$

Taking an opposing perspective, Ghosh, Gu and Jain (2005) argue that earnings string firms that are able to generate consistent revenue increases do not need to resort to earnings management to sustain their patterns of earnings increases. They predict that firms with "strong" revenue-supported earnings growth do not need to rely on income-increasing earnings management as compared to earnings string firms without sustained revenue increases. Ghosh et al. (2005) define sustained increases as increases for five consecutive years. Their sample consists of all firms from 1980 to 2000 that report at least five consecutive years of earnings increases. Two thirds of their sample firms report concurrent sustained increases in revenues during the earnings string periods. They test for earnings management using discretionary accruals,

${ }^{3}$ I am assuming that earnings string patterns become increasingly unsustainable based on the fact that they break in year $t$. The type I error I commit will be that some firms break their earnings strings for reasons unrelated to sustainability. The type II error I commit is that some firms do not break their earnings strings despite facing increasing difficulties trying to sustain their earnings strings. Both errors reduce the power of my tests. 
estimated as the residuals from the cross-sectional modified Jones model. They also use changes in special items and share repurchases as alternative measures of earnings management.

Their results show that earnings string firms without concurrent sustained revenue increases are more likely to achieve earnings growth through income-increasing earnings management than firms with concurrent sustained revenue and earnings increases. They find a statistically significant increase in discretionary accruals of 1.9 percent of total assets (t-statistic: $3.16, \mathrm{p}<0.001)$, on average, for sample firms without concurrent sustained revenue increases as compared to firms with concurrent sustained revenue increases. They do not find any statistical differences in means for special items and share repurchases, although firms without concurrent revenue increases appear to have slightly more share repurchases. Overall, Ghosh et al. (2005) conclude that there appears to be no evidence to suggest that earnings string firms that report concurrent sustained revenue increases achieve their earnings growth through income-increasing earnings management. On the other hand, there is evidence to suggest that earnings string firms without strong revenue growth during the earnings string period engage in income-increasing earnings management to sustain their earnings growth.

I interpret the results of my earnings management results as consistent with Ghosh et al.'s (2005) findings. Both studies support the notion that managers, when faced with the difficulty of sustaining a series of consecutive annual earnings increases, will resort to incomeincreasing earnings management to meet or beat earnings benchmarks. Ghosh et al. find firms seemingly rely on income-increasing earnings management to meet earnings targets when 
revenue growth declines. I find evidence of income-increasing earnings management when the earnings string pattern is poised to break.

\subsection{Incentives}

There are at least four reasons why managers of earnings string firms would want to continue to report consecutive earnings increases. These reasons include the desire to beat earnings targets, to maintain (or increase) equity valuations, to reduce the probability of forced turnover and to increase compensation. I discuss each of these motivations and their related research.

\subsubsection{Desire to beat earnings targets}

The literature has provided evidence to suggest that managers care a lot about beating certain earnings targets. Graham, Harvey and Rajgopal (2005) provide survey evidence that managers state they are concerned with meeting earnings targets such as loss avoidance, previous period's earnings and analyst forecasts. Managers claim to believe that meeting or exceeding earnings benchmarks builds credibility with the market and helps to maintain stock prices. Furthermore, managers perceive that the market is averse to an unexpected earnings shortfall; hence they are inclined to take actions to meet or beat earnings benchmarks.

The survey evidence also indicates that managers are more willing to choose real actions (e.g., overproducing or giving sales discounts) to meet earnings targets than to use accounting 
accrual choices to meet earnings targets (such as drawing down reserves, postponing an accounting charge or altering accounting assumptions). This result may reflect unwillingness on the part of managers completing the survey to admit to accounting manipulation. On the other hand, it may suggest that managers use accruals manipulation as a last resort to meet earnings targets, consistent with the findings in this paper.

The earnings management literature has also produced empirical evidence consistent with the notion that managers care about meeting earnings benchmarks. Specifically, Burgstahler and Dichev (1997) and Degeorge et al. (1999) document an unusually large number of firms that meet or just exceed earnings thresholds (avoiding losses, meeting last year's earnings and meeting consensus analyst forecasts) and an unusually small number of firms that just miss these thresholds. The authors interpret their findings as prima facie evidence that managers will manage earnings to avoid reporting losses and earnings declines.

\subsubsection{Valuation incentives}

Research suggests that managers have incentives to maintain patterns of earnings growth, because growth has valuation implications. Graham et al. (2005) report that managers perceive that a failure to meet an earnings benchmark after doing consistently for a period of time sends a signal to the market that the firm has poor future prospects. ${ }^{4}$ To avoid sending such

${ }^{4}$ The survey evidence in Graham et al. (2005) indicates that managers consider the two top consequences of failing to meet earnings benchmarks are an increase in investors' uncertainty about future prospects and a perception among outsiders that there are deep, previously unknown problems in the firm. 
a signal to the market, managers are motivated to maintain a pattern of meeting or beating earnings thresholds. Second, Barth et al. (1999) document that firms reporting a consistent series of earnings increases are valued higher than other comparable firms, and that the valuation premium for these earnings string firms disappears when the earnings pattern is broken. Thus, managers seeking to preserve equity valuations would have incentives to meet earnings thresholds.

Burgstahler and Dichev (1997) provide evidence to suggest that managerial incentives to avoid earnings decreases become stronger with the length of the previous run of earnings increases. They document a higher frequency of avoiding an earnings decrease for the sample of firms that have three or more prior years of earnings increases, as compared to the sample of firms that report one to two prior years of earnings increases, as compared to the sample of firms that previously report an earnings decrease. They interpret their results as suggesting that managers of firms with previous earnings increases are motivated to keep reporting earnings increases. However, they do not directly test whether managers of earnings string firms use accruals management to extend these earnings strings.

\subsubsection{Career concerns}

Prior research establishes that there is a negative association between firm performance and CEO turnover, specifically CEOs are more likely to leave the firm when stock price or accounting performance deteriorates (Coughlan and Schmidt 1985; Warner, Watts and Wruck 
1988; Weisbach 1988; Murphy and Zimmerman 1993). These results support the notion that boards of directors act to replace managers of poorly performing firms. To the extent managers of earnings string firms are concerned that the prospect of reporting an earnings decrease during their tenure will have a detrimental effect on their careers, they may resort to income-increasing earnings management activities to preserve the earnings string pattern.

This concern is more pronounced given that recent studies provide further evidence to suggest that boards of directors do not focus on performance alone, but rather on deviation from expected performance (Farrell and Whidbee 2003; Dikolli, Mayew and Nanda 2008). Farrell and Whidbee (2003) find an inverse relation between the likelihood of CEO turnover and analyst forecast errors. They argue that to the extent forecast errors capture the component of firm performance that the board attributes to CEO performance, a negative forecast error sends a signal to the board of directors that the CEO is underperforming. Dikolli et al. (2008) find that CEO turnover is more sensitive to seasonally adjusted earnings changes than to analyst forecast errors. Their results show that the likelihood of CEO turnover increases in the number of past negative quarterly earnings surprises, measured relative either to last period's earnings or to analyst forecasts. For managers of firms that have been reporting consistent earnings increases, it is possible that a reported earnings decrease could send a strong negative signal to directors. Hence, these managers would be inclined to maintain their earnings string patterns.

Other studies also provide evidence that managers are motivated by career concerns. For example, Kothari, Shu and Wysocki (2007) find evidence that managers prefer to delay the 
disclosure of bad news relative to good news, as a result of career concerns. Managers appear to reveal good news to investors quickly but they accumulate bad news up to a certain threshold.

Kothari et al.'s results (i.e., that managers, on average, delay the release of bad news to investors) do not contradict other findings that suggest managers have incentives to disclose bad news early because they wish to avoid litigation (Skinner 1994; Kasznik and Lev 1995). In these papers, the empirical question is whether managers will issue an early warning to investors in the face of impending (unavoidable) bad news. In contrast, Kothari et al. (2007) hypothesize that managers will not report bad news until they can no longer avoid doing so. Instead, they will act strategically by accumulating bad news (instead of disseminating bad news as soon as it arrives) up to a certain threshold beyond which it is too costly or difficult to withhold the bad news, and then disclose all the accumulated bad news at once. The manager withholds bad news because he hopes that good news will arrive and offset the accumulated bad news.

Withholding bad news (up to a certain threshold) is consistent with managers of earnings string firms using income-increasing earnings management to delay the break in their earnings string patterns. For example, Dechow, Richardson and Tuna (2000) investigate five motivations for meeting or beating earnings thresholds, and find that the two main motivations for these actions are to delay the reporting of bad news and to avoid a stock downgrade. ${ }^{5}$

${ }^{5}$ The other three motivations which they examine but do not find evidence to support are: to issue equity at more favorable prices, to avoid earnings-based debt covenant restrictions and to meet exchange listing requirements. 


\subsubsection{Compensation incentives}

As stock market valuations increased dramatically since the 1980s, and managers have increasingly been compensated with stock-based compensation, managers have become increasingly sensitive to the level of their firms' stock prices. ${ }^{6}$ A number of earnings management studies show that there is a positive association between earnings management and equity incentives (Bergstresser and Philippon 2005; Cheng and Warfield 2005; Burns and Kedia 2006).

Bergstresser and Philippon (2005) find that discretionary accruals, as measured by the modified Jones model, are more actively used at firms whose CEO compensation is more closely linked to the value of the stock. They interpret this finding to suggest that CEOs aggressively use the discretionary components of earnings to affect their firms' reported performance. The authors also find that CEOs exercise (sell) large quantities of options (shares) during years of high accruals, consistent with the notion that discretionary accruals are opportunistic.

Burns and Kedia (2006) examine whether executive stock options generate incentives for misreporting earnings management by examining restatement firms over the period 1995-2002. They show that the stock price sensitivity of the CEO's option compensation is positively associated with the firm's propensity to misreport. They argue that this result occurs because option compensation is a convex function of stock price; the CEO is rewarded if stock price

${ }^{6}$ Hall and Liebman (1998) show that the median exposure of CEO wealth to firm stock prices tripled between 1980 and 1994, and doubled again between 1994 and 2000. 
increases as a result of aggressive accounting, but is not penalized as much by a decline in stock price.

Cheng and Warfield (2005) also find that equity incentives lead to earnings management. Using stock-based compensation data over the 1993-2000 time period, Cheng and Warfield document that managers with high equity incentives are more likely to report earnings that meet or beat analyst forecasts and less likely to report large positive earnings surprises. Their finding is consistent with the notion that managers have incentives to either reserve current earnings to avoid future earnings disappointments or to boost current earnings to avoid an earnings shortfall. That is, their study suggests that managers will act to maintain patterns of earnings increases for compensation reasons if their wealth is sensitive to the firm's stock performance due to large stock or options holdings.

It is possible that managers might also bias earnings downwards due to stock option compensation. Specifically, Baker, Collins and Reitenga (2003) find that relatively high option compensation is associated with income-decreasing discretionary accruals in the periods preceding option award dates. McAnally, Srivastava and Weaver (2008) find that managers with large stock option grants are more likely to miss earnings targets, if doing so can cause stock price to slide sharply and thereby reward managers with a lower strike price on stock options issued at-the-money. Specifically, the authors find evidence that CEO option grants increase when firms miss earnings targets by reporting small losses or small earnings decreases over the previous year for a sample of 1,744 firms over 1993-2004. However, neither Baker et al. nor 
McAnally et al. examine firms that report consistent earnings increases. It is not clear whether managers of earnings string firms would break their earnings string patterns so as to obtain favorable strike prices for their option grants. 


\section{Motivation and Hypothesis Development}

Taken together, previous research suggests that managers have incentives to meet or exceed earnings targets. However, it is unresolved whether, and to what extent, firms that consistently meet or beat earnings targets rely on earnings management to do so. This question is important because practitioners and regulators sometimes take the view that earnings management to meet earnings thresholds is pervasive and problematic (Dechow and Skinner 2000). Under this view, consistently meeting or beating earnings targets is taken as prima facie evidence of earnings management (Levitt 1998).

For example, Jensen (2005) asserts that managers who consistently meet or beat earnings thresholds must be managing earnings. He asserts that "the only way for managers to meet expectations year in and out is to cook their numbers to mask the inherent uncertainty in their business" (p. 7). He believes there is mounting evidence to suggest that earnings manipulation to meet earnings targets is widespread, and that producing numbers to meet market expectations has been viewed as acceptable, normal business practice in the last two decades. Jensen cites statistics showing that firms that restate their annual audited financial statements reached a record high of 253 firms in 2004 (a 23\% increase over 2003). Jensen also discusses several earnings restatement examples showing how the impact of overvalued equity distorts managerial 
incentives to benefit shareholders, including Enron, Nortel and eToys. ${ }^{1}$ However, Jensen does not present empirical evidence beyond several examples. My research presents large-sample evidence on the issue of whether managers of earnings string firms resort to income-increasing earnings management to extend their earnings string patterns.

\subsection{Earnings management hypothesis}

I hypothesize that managers will use income-increasing earnings management to stretch an increasing earnings pattern. Alternatively said, managers will use income-increasing earnings management to delay the reporting of an earnings decrease after a series of consecutive annual earnings increases.

As discussed earlier, the basis for this hypothesis is drawn from prior research that suggests managers will act to preserve the pattern of earnings increases, for at least four reasons a desire to beat earnings targets, to maintain (or increase) equity valuations, to reduce the probability of forced turnover and to increase compensation. I conduct valuation tests (discussed in section 5.5) to show that earnings string firms have higher valuations than non-earnings string

\footnotetext{
${ }^{1}$ Specifically, Enron's managers chose to reaffirm the market's expectations for their firm's stock valuation by engaging in various questionable practices (such as hiding debt through off-balance sheet partnerships) to meet or beat their earnings targets. Nortel tried to report high earnings growth by buying earnings via acquisitions which subsequently were written off, and eToys tried to satisfy growth expectations by relying on cheap capital (during the dotcom boom) to raise sales through unsuccessful projects and excessive internal spending. Jensen states that a failure to create real earnings growth (through real actions) may lead managers to turn to accounting manipulations and fraudulent practices to continue the appearance of growth and value creation.
} 
firms. I also examine turnover patterns of CEOs surrounding the earnings break year. ${ }^{2}$ Both tests provide results suggesting that these are incentives that induce managers to act to preserve earnings string patterns. I do not examine the effect of stock option compensation on my sample of earnings string firms for two reasons. First, prior research suggests managers might want to increase or decrease earnings, depending on whether they wish to exercise options or receive a favorable stock price. Second, data on stock option grants are not available during much of my sample period. However, I assume, based on prior research, that managers of earnings string firms are rewarded (either in cash or equity) for reporting consistent earnings increases; hence they have financial incentives to want to continue the series of consecutive annual earnings increases.

I hypothesize that managers of earnings string firms initiate income-increasing earnings management activities two years before the earnings string break because prior research finds evidence that managers appear to behave in ways that suggest they know approximately when the earnings strings of their firms will break. Specifically, Ke, Huddart and Petroni (2003) report that insider selling increases significantly three to nine quarters prior to a break in a string of consecutive quarterly earnings increases and ceases in the two quarters immediately prior to the break, possibly to avoid litigation risk. Their findings suggest that managers are able to anticipate an impending earnings break up to two years in advance. They do not examine earnings

\footnotetext{
2 Based on available CEO data for S\&P 1500 firms between 1992-2006, I tabulate 81and 96 CEO departures in year $t-2$ and year $t-1$ of the earnings string period, 126 CEO departures in the year of the earnings break, and 153 in the following year.
} 
management in the two years leading to the break in the earnings string patterns. Based on their research, I hypothesize that managers, on average, use income-increasing earnings management during the period preceding an earnings string break so that they are able to continue to report rising earnings despite a deterioration in the firm's fundamentals.

I examine firms with earnings increases rather than other earnings targets (loss avoidance, analyst forecasts) for two reasons. First, while prior research shows that firms that habitually meet or beat analyst forecasts are rewarded with a market premium (Kasznik and McNichols 2002; Bartov, Givoly and Hayn 2002), it is not clear whether managers of analyst forecast string firms are able to anticipate that their firms will break their analyst forecast earnings strings several years in advance. Specifically, I am not aware of studies similar to Ke et al. (2003) that show managers that consistently meet or beat analyst forecasts can predict an impending break in their analyst forecast strings.

Second, the characteristic which differentiates the earnings increase string setting from other settings is that while a firm might meet or exceed analysts' forecasts indefinitely, an earnings string firm cannot continue to report higher earnings indefinitely. Eventually, the earnings growth ceases. My research contributes to the earnings management literature by examining whether managers use income-increasing earnings management to prop up what might be an otherwise shorter earnings string period. This setting increases the power of earnings management tests because managers who wish to extend their earnings string patterns 
of earnings increases must resort to income-increasing earnings management. ${ }^{3}$ In contrast, prior research has shown that managers can use expectations management to "walk-down" optimistic analyst forecasts if they believe these forecasts will not be achieved (Matsumoto 2002;

Richardson, Teoh and Wysocki 2004). Hence, analyst expectations become a moving target which managers can influence by means other than income-increasing earnings management. On the other hand, some analysts may not revise their optimistic forecasts despite managers' attempts to guide them. Overall, it is unclear that a failure to beat analyst forecasts is due to deteriorating firm fundamentals, inadequate income-increasing earnings management, or poorly executed expectations management.

My first hypothesis (in alternative form) is as follows:

H1: Managers of earnings string firms engage in income-increasing earnings management in the last two years prior to the break in their earnings string patterns.

\subsection{Earnings management constraint hypothesis}

The use of income-increasing earnings management to extend an earnings string is limited by the accounting flexibility available to managers to manipulate earnings upwards. The

${ }^{3}$ I perform an exploratory study on firms that meet or beat analyst forecasts for three or more consecutive years and I do not find evidence of income-increasing earnings management in the year before the analyst forecast earnings strings break. 
articulation between the income statement and the balance sheet implies that accruals that pass through the income statement stay on the balance sheet as net operating assets until they are reversed out or realized as cash. That is, income-increasing earnings management increases both the current period's earnings and balance sheet net assets. Therefore, if managers continue to make optimistically biased estimates and judgments in each period and fail to reverse the income-boosting effect of prior periods' accruals, they will eventually overstate the balance sheet. Ultimately, this form of income-increasing earnings management is not sustainable. Because of the reversing nature of accounting accruals, managers have to undo their previous optimistic accounting choices if they wish to stay within the constraints imposed by GAAP. ${ }^{4}$

Barton and Simko (2002) test the hypothesis that firms with higher net operating assets relative to sales have less accounting flexibility to manipulate earnings. Their objective is to examine why some firms apparently miss earnings forecasts even by a cent if managers know that the penalty of a missed expectation is a substantial stock price decrease. They posit that firms that miss forecasts have exhausted their ability to manage earnings upwards. They use the ratio of net operating assets relative to sales (NOA ratio) as their proxy for managers' previous biased reporting choices. They find that firms with higher net operating assets relative to sales also report larger cumulative levels of income-increasing accruals and that the likelihood of firms meeting or beating an earnings benchmark decreases with the level of net operating assets

${ }^{4}$ Palmrose and Scholz (2004) provide descriptive evidence that overstating revenues and overstating assets (by understating expenses) are the most common reasons for financial statement restatements. 37 percent of their restatement sample (184 of 492 firms) overstates revenues and another 34 percent (165 of 492 firms) of their sample understates expenses. Of these 165 firms, 102 understate accrued expenses. 
relative to sales. Their results are stronger when they use the ratio of working capital net operating assets relative to sales (WCNOA ratio). Overall, their results suggest that the ability to meet or beat earnings benchmarks varies as a function of previous optimism in financial reporting.

I extend Barton and Simko (2002) by identifying whether firms with consecutive annual earnings increases have reduced accounting flexibility to manage earnings upwards when they break their earnings strings. My second hypothesis (in alternative form) is as follows:

H2: The likelihood of firms breaking their earnings string patterns is positively associated with the level of net operating assets relative to sales.

I test this hypothesis by investigating whether there is an over-time increase in the NOA (WCNOA) ratio for earnings string firms during their periods of rising earnings. I also examine whether the likelihood of an earnings break is positively correlated with higher NOA (WCNOA) ratios. 


\section{Research Design}

\subsection{Earnings management measures}

My measure of earnings management is the signed level of discretionary accruals from the cross-sectional modified Jones model (Jones 1991; Dechow, Sloan and Sweeney 1995). This measure captures the extent of income-increasing earnings management after controlling for changes in sales and levels in plant, property and equipment (PPE).

The modified Jones model is estimated cross-sectionally each year between 1951-2006 using all Compustat firms in the same two-digit SIC code:

$$
\mathrm{TA}_{i, t}=\mathrm{a}_{1}\left(1 / \operatorname{ASSETS}_{i, t-1}\right)+\mathrm{a}_{2}\left(\Delta \mathrm{REV}_{i, t}-\Delta \mathrm{REC}_{i, t}\right)+\mathrm{a}_{3}\left(\mathrm{PPE}_{i, t}\right)+\varepsilon_{i, t}
$$

where $\mathrm{TA}_{i, t}$ represents the total accruals of firm $i$ at time $t$, scaled by lagged total assets of firm $i$ at time $t-1,\left(\Delta \mathrm{REV}_{i, t}-\Delta \mathrm{REC}_{i, t}\right)$ represents the change in revenue less the change in accounts receivable scaled by lagged total assets and $\mathrm{PPE}_{i, t}$ is property, plant and equipment scaled by lagged total assets.

Total accruals $\left(\mathrm{TA}_{i, t}\right)$ are computed as:

$\mathrm{TA}_{i, t}=\left(\Delta \mathrm{CA}_{i, t}-\Delta \mathrm{CL}_{i, t}-\Delta \mathrm{Cash}_{i, t}-\Delta \mathrm{ST} \operatorname{Debt}_{i, t}-\right.$ Depreciation $\left._{i, t}\right) /\left(\right.$ Total Assets $\left._{i, t-1}\right)$ 
where CA is current assets (Compustat \#4), CL is current liabilities (Compustat \#5), cash is Compustat \#1, short term debt is Compustat \#34, depreciation is Compustat \#14 and total assets is Compustat \#6. I require at least 10 firm-year observations for each two-digit SIC code. From the coefficient estimates of the modified Jones model regression, I measure discretionary accruals $\left(\mathrm{DA}_{i, t}\right)$ for each firm-year observation as follows:

$$
\begin{aligned}
& \mathrm{DA}_{i, t}=\mathrm{TA}_{i, t}-\mathrm{NDA}_{i, t} \\
& \mathrm{NDA}_{i, t}=\hat{\mathrm{a}}_{1}\left(1 / \operatorname{ASSETS}_{i, t-1}\right)+\hat{\mathrm{a}}_{2}\left(\Delta \mathrm{REV}_{i, t}-\Delta \mathrm{REC}_{i, t}\right)+\hat{\mathrm{a}}_{3}\left(\mathrm{PPE}_{i, t}\right)
\end{aligned}
$$

Thus, non-discretionary accruals $\left(\mathrm{NDA}_{i, t}\right)$ are based on the fitted values from the crosssectional modified Jones model and $\mathrm{DA}_{i, t}$ are the residuals obtained after subtracting firm $i$ 's nondiscretionary accruals in year $t$ from total accruals.

Prior research has shown that there is a positive relation between discretionary accruals and firm performance (Dechow et al. 1995; Kothari et al. 2005). Since my sample is composed of firms with improving accounting performance through time, it is necessary to control for the effect of performance to reduce any performance-induced bias in my discretionary accrual estimates. I control for the effect of accounting performance using two different methods following Kothari et al. (2005).

My first method adds a performance measure $\left(\mathrm{ROA}_{i, t}\right)$ to the modified Jones model as an additional regressor. The advantage of this method is that it imposes no new data requirements. 
The disadvantage of the regression approach is that it imposes linearity on the relation between performance and accruals. Specifically, I re-estimate the modified Jones model as follows:

$$
\begin{gathered}
\mathrm{TA}_{i, t}=\mathrm{a}_{1}\left(1 / \mathrm{ASSETS}_{i, t-1}\right)+\mathrm{a}_{2}\left(\Delta \mathrm{REV}_{i, t}-\Delta \mathrm{REC}_{i, t}\right)+\mathrm{a}_{3}\left(\mathrm{PPE}_{i, t}\right)+\mathrm{a}_{4}\left(\mathrm{ROA}_{i, t}\right)+\varepsilon_{i, t} \\
\text { Performance-adjusted } \mathrm{DA}_{i, t}=\mathrm{TA}_{i, t}-\hat{\mathrm{a}}_{1}\left(1 / \mathrm{ASSETS}_{i, t-1}\right)-\hat{\mathrm{a}}_{2}\left(\Delta \mathrm{REV}_{i, t}-\Delta \mathrm{REC}_{i, t}\right) \\
-\hat{\mathrm{a}}_{3}\left(\mathrm{PPE}_{i, t}\right)-\hat{\mathrm{a}}_{4}\left(\mathrm{ROA}_{i, t}\right)
\end{gathered}
$$

The second method is the performance-matching technique described in Kothari et al. (2005). This technique utilizes a matched sample design by implementing a one-to-one match for each firm-year in the earnings string sample with another firm from the same industry (2-digit SIC code) and year with the closest ROA to the earnings string firm. The control sample is drawn from firm-year observations belonging to non-earnings string firms. The performance-matched discretionary accrual for firm $i$ in year $t$ is then calculated as the earnings string firm's discretionary accrual in year $t$ minus the control firm's discretionary accrual in year $t$. Specifically, I estimate my measure of performance-matched discretionary accruals as follows: Performance-matched $\mathrm{DA}_{i, t}=\mathrm{DA}_{i, t}$ of firm $i$ in year $t-\mathrm{DA}_{j, t}$ of control firm $j$ in year $t$ Kothari et al. (2005) find that performance matching performs as well as or better than the regression approach. However, this method requires a matched sample which reduces the sample size. Thus, I conduct my earnings management tests using both performance-adjusted and performance-matched discretionary accruals. 


\subsection{Earnings management constraint measures}

Barton and Simko (2002) posit that GAAP reporting limits the extent to which managers can opportunistically increase reported earnings, because the balance sheet accumulates the effects of previous accounting choices. Accounting choices that increase earnings on the income statement will also increase net assets on the balance sheet, and the effect is cumulative. All firms should have some available (but unobservable) accounting flexibility that can be used by managers to bias earnings upwards. Because assets that have already been biased upwards this year are not available to be used by managers to manipulate earnings upwards again next year, the balance sheet numbers provide an empirical indicator of the cumulative effects of incomeincreasing earnings management.

Barton and Simko (2002) use net operating assets relative to sales to measure the extent of past earnings management. Net operating assets (NOA) is calculated as follows:

$\mathrm{NOA}=$ Shareholders' equity (Compustat \#60) + total debt (Compustat \#9+\#34)

- cash and marketable securities (Compustat \#1)

The NOA ratio is obtained by dividing net operating assets by sales (Compustat \#12). Barton and Simko (2002) argue that, if managers have been repeatedly biasing earnings upwards, the NOA ratio should also be trending up. However, this relation is also affected by the firm's operational decisions. Because the NOA ratio captures productivity (or efficiency) of assets 
relative to sales, changes in productivity add noise to the NOA ratio as an empirical proxy for the earnings management constraint.

I also examine a measure of the balance sheet earnings management constraint that uses the working capital component of net operating assets (WCNOA), defined as follows:

WCNOA = current assets (Compustat \#4) - current liabilities (Compustat \#5)

+ current debt (Compustat \#34) - cash and marketable securities (Compustat \#1)

As with the NOA ratio, I divide WCNOA by sales to compute the WCNOA ratio. The interpretation of the WCNOA ratio is similar to that of the NOA ratio. However, the separation of net operating assets into its short term and long term components is useful if current operating assets more precisely reflect the effects of earnings management, relative to total operating assets. Barton and Simko (2002) find that the power of their tests increases when they use the WCNOA ratio as compared to the NOA ratio. This follows from earnings management studies which suggest that current accruals are more often managed than long-term accruals (Guenther 1994; Teoh, Welch and Wong 1998a; Teoh, Wong and Rao 1998). Specifically, Teoh et al. decompose discretionary accruals into discretionary current and long term accruals. They expect discretionary current accruals to be more easily managed than long term accruals and find 
evidence consistent with their predictions. ${ }^{1}$ DeFond and Jiambalvo (1994) find that discretionary working capital accruals are positive and significant whereas discretionary total accruals are positive but not significant in their earnings management tests which examine firms that are close to debt covenant violations. Thus, I use both the NOA ratio and the WCNOA ratio as my empirical proxies for the cumulative effects of earnings management.

Following Barton and Simko, several other researchers also use either the NOA ratio or the WCNOA ratio to measure earnings management constraint. Smith (2004) examines the association between earnings management constraints and the market reaction to earnings surprises. His paper includes a replication of Barton and Simko's logistic regression results. He obtains similar findings showing that there is a positive association between the probability of meeting or beating analyst forecasts and the NOA ratio. Hirshleifer, Hou, Teoh and Zhang (2004) examine whether investors overvalue firms with bloated balance sheets. They find that a high NOA ratio is associated with earnings that trend upward over several years but subsequently reverse sharply. Cheng and Warfield (2005) use the NOA variable as a control variable in their earnings management tests, and consistent with NOA as a measure of earnings management constraint, they find a negative relation between discretionary accruals and beginning period NOA ratio.

${ }^{1}$ The authors argue that managers can more easily increase current accruals by advancing the recognition of revenues with credit sales, or delaying the recognition of current expenses compared to long-term accrual adjustments such as decelerating depreciation, decreasing deferred taxes or realizing unusual gains. 
Finally, Ettredge, Scholz, Smith and Sun (2007) examine the association between misstatements and firms' WCNOA ratios. They find that accounting frauds or non-fraudulent earnings misstatements are preceded by significantly higher WCNOA ratios, and the association strengthens as the restatement event approaches (i.e., as the misstatement is detected).

Because the level of net operating assets relative to sales has been shown to vary across industries (Nissim and Penman 2001), I also use an industry-adjusted version of the NOA ratio. The industry-adjusted NOA ratio for firm $i$ in year $t$ is calculated as its NOA ratio in year $t$ minus the median NOA ratio of its two-digit SIC code in year $t$. A positive (negative) value suggests that the firm's NOA ratio is higher (lower) than its industry's median NOA ratio. I interpret a positive value for the industry-adjusted NOA ratio as indicating that the firm has been engaging in more income-increasing earnings management, relative to its industry peers. I also obtain an industry adjusted measure for the WCNOA ratio (industry-adjusted WCNOA ratio), defined analogously to the industry-adjusted NOA ratio.

\subsection{Earnings management model}

My first hypothesis posits that managers of earnings string firms engage in incomeincreasing earnings management in the last two years of their earnings string pattern. To test for income-increasing earnings management, I estimate the following regression separately for each of the three earnings string samples as described earlier: 


$$
\begin{aligned}
& \mathrm{EM}_{i, t}=a_{0}+\sum_{n=1}^{3} a_{\mathrm{n}}\left(\operatorname{PREBREAK}_{i, t}\right)+a_{4}\left(\mathrm{BEGSTRING}_{i, t}\right)+a_{5}\left(\mathrm{SIZE}_{i, t}\right)+a_{6}\left(\operatorname{LEVERAGE}_{i, t}\right) \\
& +a_{7}\left(\mathrm{GROWTH}_{i, t}\right)+a_{8}\left(\mathrm{FIRM} \mathrm{AGE}_{i, t}\right)+\mu_{i, t}
\end{aligned}
$$

$\mathrm{EM}_{i, t}$ is the signed magnitude of the accrual-based earnings management measure (as defined earlier) for firm $i$ in year $t$. Firm-year observations are arranged in event time in relation to the year of the earnings break. PREBREAK $n$ are indicator variables set equal to one if the firmyear observation in the earnings string period is $n$ years before the break in the earnings pattern and 0 otherwise. Thus, PREBREAK1 denotes firm-year observations one year before the earnings string breaks and PREBREAK2 (PREBREAK3) denotes firm-year observations two (three) years before the earnings string breaks.

BEGSTRING denotes firm-year observations that precede the earnings break by more than three years, within the earnings string. Every firm-year observation that is part of the earnings string period as defined will have one indicator variable $=1$ and the rest as zero. The benchmark sample's firm-year observations (i.e., firm-year observations that are not part of the earnings string sample) have all indicator variables coded as zero.

I test for evidence of income-increasing earnings management in each of the three years prior to the break in the earnings pattern (i.e., PREBREAK1, PREBREAK2 and PREBREAK3). A positive coefficient on PREBREAK $\left(a_{n}>0\right)$ is interpreted as earnings string firms reporting a higher signed level of discretionary accruals relative to the average non-earnings string firm. My 
first hypothesis predicts a positive coefficient for both PREBREAK1 and PREBREAK2 and makes no prediction for PREBREAK3 and BEGSTRING. That is, I expect to find evidence of incomeincreasing earnings management in earnings string firms in the last two years of their earnings string period.

My controls in the regression model are SIZE, LEVERAGE, GROWTH and FIRM AGE. SIZE is the natural logarithm of total assets in year $t$. LEVERAGE is total debt/total assets in year t. GROWTH is the natural logarithm of the two-year annualized growth in book value of equity. FIRM AGE is the natural logarithm of the firm's age in year $t$, measured as the difference between year $t$ and when the firm first appears in the Compustat annual database.

I include SIZE as a control variable because prior earnings management research shows that medium and large firms engage more extensively in earnings management to avoid earnings decreases than small firms (Burgstahler and Dichev 1997). On the other hand, a larger firm may find it harder to manipulate earnings due to better corporate governance, political costs and tighter scrutiny from the market. Thus I do not have a prediction for the coefficient on SIZE. I include LEVERAGE as a control variable because managers have been shown to have incentives to manage earnings to avoid debt covenants' violations (Watts and Zimmerman 1990; DeFond and Jiambalvo 1994). I expect the coefficient on LEVERAGE to be positive. I include GROWTH as a control variable because prior research suggests that high growth firms have stronger incentives to avoid earnings disappointments so as to avoid the 'torpedo' effect of a large negative market reaction (Skinner and Sloan 2002). Thus I expect the coefficient on GROWTH to 
be positive. I include FIRM AGE as a control variable because prior research shows that earnings quality improves for mature firms relative to young firms (Ecker, Francis, Kim, Olsson and Schipper 2006). A firm with poor earnings quality could have either abnormally high or low discretionary accruals. Thus, I do not have a prediction for the coefficient on FIRM AGE.

\subsection{Earnings management constraint model}

To test my second hypothesis, I use logistic regressions to model the probability that an earnings string firm will break its earnings string pattern:

$$
\begin{gathered}
\text { Prob }\left(\text { BREAK=1)= } \beta_{0}+\beta_{1} \text { EMC }_{i, t-1}+\beta_{2} \text { SIZE }_{i, t}+\beta_{3} \text { LEVERAGE }_{i, t}+\beta_{4} \text { GROWTH }_{i, t}+\right. \\
\beta_{5} \text { FIRM AGE }_{i, t}+\varepsilon_{i, t}
\end{gathered}
$$

where BREAK = 1 if the firm experiences a break in the earnings pattern (i.e., fails to report an earnings increase) and 0 if the firm is still within the earnings string period (i.e., reports an earnings increase). The earnings management constraint variable, $\mathrm{EMC}_{i, t-1,}$, is the variable of interest. It denotes the amount of balance sheet accounting flexibility. I use four measures of accounting flexibility - NOA and WCNOA ratios and their industry-adjusted counterparts. I use the ratios' beginning values to obtain ex-ante measures of the amount of accounting flexibility available to managers to bias earnings upwards in the current year. That is, my logistic regression tests assess whether the probability of breaking the earnings string in a given year is associated 
with the lack of accounting flexibility at the beginning of that year. This treatment is consistent with Barton and Simko (2002). H2 predicts a positive association between BREAK and $\mathrm{EMC}_{i, t-1}$ $\left(\beta_{1}>0\right)$.

I use SIZE and FIRM AGE as control variables to account for the changing characteristics in my sample. Older and larger firms may face difficulties reporting an earnings increase. Thus I expect the coefficients on SIZE and FIRM AGE to be positive. I use LEVERAGE as a control variable to proxy for financial distress. I expect firms with higher debt to have greater difficulty meeting their debt and interest obligations. Because interest payments reduce earnings, as opposed to dividend payments, I expect to find a positive association between the probability of reporting an earnings decrease and leverage $\left(\beta_{3}>0\right)$. All else equal, I expect firms with a higher growth rate to have less difficulty reporting an earnings increase. Thus, I expect a negative coefficient on GROWTH. 


\section{Main Empirical Tests}

\subsection{Sample selection}

I start with all firm-year observations from the CRSP/COMPUSTAT annual industrial merged database. I define an earnings string period as a period in which a firm reports at least three consecutive years of increases in split-adjusted current year's annual earnings per share (Compustat \#58) compared to last year's earnings per share. ${ }^{1}$ I trace the duration of these earnings strings through their respective firms' histories until the firms fail to report an annual earnings increase ("earnings break"). I define an earnings break as current year's split-adjusted annual earnings per share that is smaller or the same as last year's annual earnings per share following at least three consecutive years of annual EPS increases. ${ }^{2}$

I exclude financial institutions and regulated industries (two-digit SIC codes 49 and 6067) to be consistent with Barton and Simko (2002). I also exclude firms with total assets or book value of equity less than $\$ 2$ million as these are either extremely small or financially distressed.

\footnotetext{
${ }^{1}$ Accounting researchers use various time horizons to define an earnings string period. Commonly used time-frames are five years or twenty quarters (Barth et al. 1999; Ghosh et al. 2005; Myers et al. 2007), three years or twelve quarters (Bartov, Givoly and Hayn 2002) and two years or eight quarters (Ke et al. 2003; Balakrishnan, Johnson and Sivaramakrishnan 2002) I choose a three year threshold to ensure that I retain sufficient sample size for my multiple string samples. I also test whether my results are robust to a different threshold requirement (described in section 6.6.4).

2 I conduct a sensitivity analysis to test whether my results are affected if I define an earnings string firm as one which the firm reports three or more consecutive years of annual earnings non-decreases (as opposed to annual earnings increases) and if I define the earnings break as an earnings string firm reporting an earnings decrease (instead of a failure to report an earnings increase). My results are unaffected.
} 
Based on these requirements, I obtain 6,130 firms between 1952-2005 that report one or more earnings strings (10,562 earnings strings in total). Panel A of Table 1 provides the sample composition based on the frequency of earnings strings. I collate the firm-year observations (27,777 firm-years) for firms which report their first earnings string (6,150 firms with 3-43 firmyear observations per firm). I label this sample as the "first earnings string sample".

2,540 firms of the first earnings string sample report a second earnings string. Of these, 1,132 firms report a third earnings string (Panel A Table 1). I collate the firm-year observations for firms which report their second earnings string (3-29 firm-year observations per firm) and for firms which report a third earnings string (3-29 firm-year observations per firm). I label these samples as the "second earnings string sample" and the "third earnings string sample" respectively. The second earnings string sample contains 11,712 firm-years over 1957-2005. The third earnings string sample contains 5,032 firm-years over 1961-2005.

Table 1 reports the composition of my three samples. Across all earnings strings, approximately 40 percent of the sample consists of earnings string firms with three years of consecutive annual EPS increases. About one fourth of the sample has four years of consecutive annual earnings increases and the remaining one third has earnings strings that are five years or longer. Relatively shorter earnings strings might bias against the results of my earnings management constraints tests since GAAP constraints limit how much earnings management (and therefore net operating assets increases) can happen per year. Panel C of Table 1 reports descriptive statistics of the length of the earnings string for the three earnings string samples. The 
median length across all three earnings string samples is four years. The statistics suggest that there are no statistically reliable differences in terms of earnings string length across the three earnings string samples. 
Table 1: Sample Composition

Panel A: Frequency distribution of earnings strings (distinct firms)

\begin{tabular}{|c|c|c|c|c|c|}
\hline Number of strings & $\underline{\text { Firms }}$ & $\underline{\%}$ & Number of strings & $\underline{\text { Firms }}$ & $\underline{\%}$ \\
\hline 1 & 3,590 & 58.6 & $>=1$ & 6,130 & 100.0 \\
\hline 2 & 1,408 & 23.0 & $>=2$ & 2,540 & 41.4 \\
\hline 3 & 639 & 10.4 & $>=3$ & 1,132 & 18.5 \\
\hline 4 & 310 & 5.1 & $>=4$ & 493 & 8.0 \\
\hline 5 & 111 & 1.8 & $>=5$ & 183 & 3.0 \\
\hline 6 & 61 & 1.0 & $>=6$ & 72 & 1.2 \\
\hline 7 & 10 & 0.2 & $>=7$ & 11 & 0.2 \\
\hline \multirow[t]{2}{*}{8} & 1 & 0.0 & $>=8$ & 1 & 0.0 \\
\hline & 6,130 & & Total & 10,562 & \\
\hline
\end{tabular}

Panel B: Frequency distribution of earnings strings' length

\begin{tabular}{|c|c|c|c|c|c|c|c|}
\hline Number of consecutive & \multicolumn{2}{|c|}{ First earnings string } & \multicolumn{2}{|c|}{ Second earnings string } & \multicolumn{2}{|c|}{ Third earnings string } & \\
\hline$\underline{\text { annual EPS increases }}$ & $\underline{\text { Firms }}$ & $\underline{\%}$ & $\underline{\text { Firms }}$ & $\underline{\%}$ & $\underline{\text { Firms }}$ & $\underline{\%}$ & \\
\hline 3 & 2,517 & 41.1 & 1,085 & 42.7 & 496 & 43.8 & \\
\hline 4 & 1,518 & 24.8 & 627 & 24.7 & 299 & 26.4 & \\
\hline $5+$ & 2,095 & 34.2 & 828 & 32.6 & 337 & 29.8 & \\
\hline \multicolumn{8}{|c|}{ Panel C: Descriptive statistics of earnings strings' length (number of years) } \\
\hline & $\underline{\text { Mean }}$ & $\underline{\text { Std dev }}$ & $\underline{\text { Min }}$ & p25 & $\underline{\text { Median }}$ & p75 & $\underline{\text { Max }}$ \\
\hline First string sample & 4.67 & 2.89 & 3.00 & 3.00 & 4.00 & 5.00 & 43.00 \\
\hline Second string sample & 4.63 & 2.67 & 3.00 & 3.00 & 4.00 & 5.00 & 29.00 \\
\hline Third string sample & 4.45 & 2.28 & 3.00 & 3.00 & 4.00 & 5.00 & 29.00 \\
\hline
\end{tabular}

\section{Notes to Table 1}

Table 1 describes the sample composition of the earnings string samples. There are 6,130 firms in the Compustat database that produce at least one or more earnings strings between 1952-2005. 2,540 of these 6,130 firms produce a subsequent second earnings string between 1957-2005 and 1,132 firms produce a third earnings string between 1961-2005. A firm is classified as an earnings string firm when it reports three or more consecutive years of annual EPS increases. An earnings string ceases to exist in the year when a firm with an earnings string fails to report an EPS increase. Panel A reports frequency statistics based on the number of earnings strings each firm reports. Panel B and C reports the frequency distribution and descriptive statistics of the length of the earnings strings respectively. 


\subsection{Descriptive statistics and correlations}

Table 2 reports summary statistics for the earnings string samples compared with the Compustat population. Firms that report their first earnings string are younger and smaller (in terms of total sales and total assets) than the average Compustat firm. Firms that report their second earnings string appear to be most comparable to the average Compustat firm in terms of size and age. As expected, firms that report their third earnings strings are older and larger than the average Compustat firm.

The growth rates of firms that report their first earnings string are higher than the average Compustat firm's growth rate in terms of mean and median change in book value of equity or total sales. The mean (median) two-year growth in book value of equity for the first earnings string sample is 32 percent (18 percent), significantly outpacing the mean (median) twoyear growth in book value of equity of the average Compustat firm $(\mathrm{p}<0.001)$. The higher growth rates of the first earnings string sample may reflect the fact that these firms are growing rapidly from a smaller base.

In contrast, the second and third earnings string samples' growth rates are more comparable with that of the average Compustat firm. The mean two-year growth in book value of equity for the second (third) earnings string sample is 15 percent (12 percent), lower than the average Compustat firm's growth rate of 21 percent, whereas the median two-year growth in book value of equity for the second (third) earnings string sample is 12 percent (11 percent), slightly higher than the average Compustat firm's median growth rate of 10 percent. 
In terms of profitability, the summary statistics indicate that firms in the earnings string samples are consistently more profitable than the average Compustat firm. Earnings per share (EPS), net income and return on assets (ROA) for earnings string firms are significantly higher $(p<0.001)$ than that of Compustat firms with the exception of mean net income for the first earnings string sample.

Table 2 also reports price and market-related variables. Earnings string firms' average stock prices are significantly higher than the average Compustat firm's, reflecting the fact that the average earnings string firm reports a higher EPS than the average Compustat firm. Because earnings string firms have been reporting consecutively increasing earnings per share for several years, a high stock price could put pressure on the managers of these firms to find creative ways to continue reporting an earnings increase.

Price-earnings ratios and market-to-book ratios for the earnings string samples tend to be lower than the average Compustat firm's, with the exception of the first earnings string sample's market-to-book ratios. However, these ratios are not conditional on differences in firm characteristics. I use price regressions to control for differences in firm characteristics so as to assess whether there is a valuation premium for earnings string firms compared to the Compustat population (described in section 5.5). These valuation tests confirm that earnings string firms earn a valuation premium compared to non-earnings string firms and provide an explanation why managers would want to extend the earnings string patterns. 
Table 2: Descriptive Statistics - Fundamentals

\begin{tabular}{|c|c|c|c|c|}
\hline & Mean & Median & $\begin{array}{l}\text { Difference } \\
\text { in means }\end{array}$ & $\begin{array}{l}\text { Difference } \\
\text { in medians }\end{array}$ \\
\hline \multicolumn{5}{|c|}{ First Earnings String Sample } \\
\hline Total Sales & 578.89 & 69.11 & $-684.11^{* * *}$ & $-26.64^{* * *}$ \\
\hline Total Assets & 601.85 & 54.36 & $-796.25^{* * *}$ & $-29.25^{* * *}$ \\
\hline Market capitalization & 864.29 & 68.91 & $-484.31^{* * *}$ & $-2.40^{* * *}$ \\
\hline \multicolumn{5}{|c|}{ Profitability and growth measures } \\
\hline Net income & 38.68 & 3.73 & $-17.18^{* * *}$ & $1.28^{* * *}$ \\
\hline Earnings per share (EPS) & 1.51 & 1.15 & $0.56^{* * *}$ & $0.48^{* * *}$ \\
\hline ROA & 0.09 & 0.09 & $0.06^{* * *}$ & $0.04^{* * *}$ \\
\hline Two-year BV growth & 0.32 & 0.18 & $0.11^{* * *}$ & $0.08^{* * *}$ \\
\hline Two-year sales growth & 0.27 & 0.18 & $0.09^{* * *}$ & $0.07^{* * *}$ \\
\hline \multicolumn{5}{|l|}{ Other measures } \\
\hline Stock price & 21.62 & 16.25 & $3.86^{* * *}$ & $4.25^{* * *}$ \\
\hline PE ratio & 17.75 & 13.86 & $-0.80^{* * *}$ & $-0.35^{* * *}$ \\
\hline MB ratio & 2.58 & 2.04 & $0.45^{* * *}$ & $0.46^{* * *}$ \\
\hline Leverage & 0.20 & 0.18 & $-0.02^{* * *}$ & $-0.03^{* * *}$ \\
\hline Firm age & 9.1 & 8 & $-4.86^{* * *}$ & $-3.00^{* * *}$ \\
\hline \multicolumn{5}{|c|}{ Second Earnings String Sample } \\
\hline \multicolumn{5}{|c|}{ Size measures } \\
\hline Total Sales & 1261.50 & 202.30 & -1.49 & $106.55^{* * *}$ \\
\hline Total Assets & 1103.19 & 146.52 & $-294.91^{* * *}$ & $62.91^{* * *}$ \\
\hline Market capitalization & 1306.14 & 119.39 & $-42.46^{*}$ & $48.08^{* * *}$ \\
\hline \multicolumn{5}{|c|}{ Profitability and growth measures } \\
\hline Net income & 77.93 & 10.05 & $22.07^{* * *}$ & $7.60^{* * *}$ \\
\hline Earnings per share (EPS) & 2.11 & 1.74 & $1.16^{* * *}$ & $1.07^{* * *}$ \\
\hline ROA & 0.09 & 0.08 & $0.06^{* * *}$ & $0.03^{* * *}$ \\
\hline Two-year BV growth & 0.15 & 0.12 & $-0.07^{* * *}$ & $0.02^{* * *}$ \\
\hline Two-year sales growth & 0.15 & 0.13 & $-0.03^{* * *}$ & $0.02^{* * *}$ \\
\hline \multicolumn{5}{|l|}{ Other measures } \\
\hline Stock price & 25.24 & 20.00 & $7.47^{* * *}$ & $8.00^{* * *}$ \\
\hline PE ratio & 14.61 & 12.19 & $-3.94^{* * *}$ & $-2.03^{* * *}$ \\
\hline MB ratio & 1.98 & 1.53 & $-0.14^{* * *}$ & $-0.05^{* * *}$ \\
\hline Leverage & 0.21 & 0.20 & $-0.01^{* * *}$ & $0.00^{*}$ \\
\hline Firm age & 17.9 & 16 & $3.88^{* * *}$ & $5.00^{* * *}$ \\
\hline
\end{tabular}


Table 2 (Continued)

\begin{tabular}{|c|c|c|c|c|}
\hline & Mean & Median & $\begin{array}{c}\text { Difference } \\
\text { in means }\end{array}$ & $\begin{array}{l}\text { Difference } \\
\text { in medians }\end{array}$ \\
\hline \multicolumn{5}{|c|}{ Third Earnings String Sample } \\
\hline$\overline{\text { Total Sales }}$ & 2319.90 & 470.38 & $1056.91^{* * *}$ & $374.63^{* * *}$ \\
\hline Total Assets & 2177.87 & 335.60 & $779.77^{* * *}$ & $251.99^{* * *}$ \\
\hline Market capitalization & 2111.60 & 263.15 & $763.00^{* * *}$ & $191.85^{* * *}$ \\
\hline \multicolumn{5}{|c|}{ Profitability and growth measures } \\
\hline Net income & 132.68 & 21.55 & $76.82^{* * *}$ & $19.10^{* * *}$ \\
\hline Earnings per share (EPS) & 2.58 & 2.18 & $1.62^{* * *}$ & $1.51^{* * *}$ \\
\hline ROA & 0.08 & 0.08 & $0.05^{* * *}$ & $0.03^{* * *}$ \\
\hline Two-year BV growth & 0.12 & 0.11 & $-0.09^{* * *}$ & $0.01^{* * *}$ \\
\hline Two-year sales growth & 0.13 & 0.11 & $-0.06^{* * *}$ & $0.01^{*}$ \\
\hline \multicolumn{5}{|l|}{ Other measures } \\
\hline$\overline{\text { Stock price }}$ & 29.22 & 25.00 & $11.45^{* * *}$ & $13.00^{* * *}$ \\
\hline PE ratio & 13.55 & 11.65 & $-5.00^{* * *}$ & $-2.57^{* * *}$ \\
\hline MB ratio & 1.90 & 1.55 & $-0.22^{* * *}$ & $-0.04^{* *}$ \\
\hline Leverage & 0.21 & 0.21 & $-0.01^{* * *}$ & 0.01 \\
\hline Firm age & 25.8 & 25 & $11.86^{* * *}$ & $14.00^{* * *}$ \\
\hline \multicolumn{5}{|l|}{ Compustat Population } \\
\hline \multicolumn{5}{|l|}{ Size measures } \\
\hline Total Sales & 1262.99 & 95.74 & & \\
\hline Total Assets & 1398.10 & 83.61 & & \\
\hline Market capitalization & 1348.60 & 71.31 & & \\
\hline \multicolumn{5}{|c|}{ Profitability and growth measures } \\
\hline Net income & 55.86 & 2.45 & & \\
\hline Earnings per share (EPS) & 0.95 & 0.67 & & \\
\hline ROA & 0.03 & 0.05 & & \\
\hline Two-year BV growth & 0.21 & 0.10 & & \\
\hline Two-year sales growth & 0.18 & 0.11 & & \\
\hline \multicolumn{5}{|l|}{ Other measures } \\
\hline Stock price & 17.77 & 12.00 & & \\
\hline PE ratio & 18.55 & 14.22 & & \\
\hline MB ratio & 2.13 & 1.58 & & \\
\hline Leverage & 0.22 & 0.20 & & \\
\hline Firm age & 14.0 & 11 & & \\
\hline
\end{tabular}

\section{Notes to Table 2}

Table 2 reports summary data for the earnings string samples computed over their entire sample period as described in Table 1 as well as the Compustat population computed over the sample period between 19512006. Total sales, total assets, market capitalization and net income are in millions of dollars. Differences in means (medians) are computed by subtracting the mean (median) value of the Compustat sample from the earnings string samples. ${ }^{* *} / * * / *$ denotes significance levels at the $1 \%, 5 \%$ and $10 \%$ level (two-tailed) respectively based on t-tests for mean differences and Wilcoxon tests for median differences. See appendix for variable definitions. 
Table 3 provides descriptive statistics on EPS changes in the years leading to the break in the earnings string pattern. Panel A of Table 3 reports the frequency distribution of the percentage change in split-adjusted earnings per share as the earnings string firms move toward the end of their earnings string patterns. The results show a wide cross-section of EPS change for firms that are reporting consistent earnings increases. However, between year $t-3$ and year $t-1$, the number of earnings string firms reporting small EPS increase (0-10\%) grows from 12.5 percent to 23.0 percent, and the number of earnings string firms reporting large EPS increases $(>50 \%)$ falls from 30.8 percent in year $t-3$ to 22.0 percent in year $t-1$. This pattern provides some support for the conjecture that earnings string firms experience greater difficulty maintaining their patterns of uninterrupted earnings growth with each successive year of reporting an EPS increase.

Panel B of Table 3 provides descriptive statistics of the magnitude of EPS change. The mean (median) EPS increases in each of the last three years of the earnings string pattern are $\$ 0.60$ (\$0.17), $\$ 0.61$ (\$0.18) and $\$ 0.69$ (\$0.17) in years $t-1, t-2$ and $t-3$ respectively. The descriptive statistics of EPS change as reported in Panel A and B of Table 3 indicate that the setting in this paper is distinct from the settings of earnings management papers that focus on firms that report small EPS changes.

Panel C of Table 3 sorts the earnings string firms into quintiles based on the magnitude of EPS change in year $t-1$. In the lowest quintile, earnings string firms report a $\$ 0.02$ increase in EPS (7.1 percent change over the previous year's EPS). In the highest quintile, earnings string firms 
report a \$0.95 increase in EPS (58.2 percent change over the previous year's EPS). Consistent with the notion that firms with large EPS increases have little reason to engage in income-increasing earnings management, the discretionary accruals for the fourth (fifth) quintile are 0.4 percent $(0.2)$ percent of total assets. In contrast, the discretionary accruals for the first, second and third quintiles of earnings string firms are 1.3 percent, 1.1 percent and 1.1 percent respectively of total assets.

I obtain a similar interpretation when I convert the modified Jones model discretionary accruals into a per share measure. Discretionary accruals per share for the first, second and third quintiles of earnings string firms are $\$ 0.02, \$ 0.06$ and $\$ 0.09$ respectively, whereas discretionary accruals per share for the fourth and fifth quintiles of firms are $\$ 0.05$ and $\$ 0.02$ respectively. The discretionary accruals per share of firms in the first three quintiles are proportionally larger with respect to their reported EPS change compared to firms in the last two quintiles. Specifically, firms in the first three quintiles report a $\$ 0.02, \$ 0.08$ and $\$ 0.17$ EPS increase whereas firms in the last two quintiles report a $\$ 0.33$ and $\$ 0.95$ EPS increase. The results suggest that firms in the lowest three quintiles rely more on income-increasing earnings management to either turn an EPS decrease to an increase or to report better results, more so than firms in the last two quintiles.

When I partition my sample based on the magnitude of EPS change in a multivariate setting (described in section 6.3), my results confirm that earnings string firms with a smaller EPS change engage in more income-increasing earnings management than earnings string firms with large EPS changes. The results thus confirm findings in previous research that show managers 
will engage in income-increasing earnings management if they are able to turn a small EPS decrease to a small EPS increase. 


\section{Table 3: Descriptive Analysis - Changes in EPS}

Panel A: Frequency distribution of change in EPS

\begin{tabular}{|c|c|c|c|c|}
\hline EPS change* $^{*}$ & $\underline{\text { Year } t}$ & $\underline{\text { Year t-1 }}$ & $\underline{\text { Year t-2 }}$ & $\underline{\text { Year t-3}}$ \\
\hline $0-10 \%$ & $21.2 \%$ & $23.0 \%$ & $14.6 \%$ & $12.5 \%$ \\
\hline $10-20 \%$ & $16.8 \%$ & $21.8 \%$ & $17.8 \%$ & $15.6 \%$ \\
\hline $20-30 \%$ & $12.7 \%$ & $14.5 \%$ & $14.3 \%$ & $13.4 \%$ \\
\hline $30-40 \%$ & $9.3 \%$ & $9.0 \%$ & $10.6 \%$ & $9.6 \%$ \\
\hline $40-50 \%$ & $7.5 \%$ & $6.6 \%$ & $7.7 \%$ & $7.2 \%$ \\
\hline Greater than $50 \%$ & $18.1 \%$ & $22.0 \%$ & $29.6 \%$ & $30.8 \%$ \\
\hline Loss firms & $14.5 \%$ & $3.1 \%$ & $5.4 \%$ & $10.9 \%$ \\
\hline
\end{tabular}

Panel B: Descriptive statistics of change in EPS

\begin{tabular}{lccccccc}
\hline EPS change & $\underline{\text { Mean }}$ & $\underline{\text { std dev }}$ & & $\underline{\mathrm{p} 25}$ & & Median & $\underline{\mathrm{p} 75}$ \\
Year $t$ & & -0.88 & 2.01 & -0.08 & -0.27 & -0.77 \\
Year $t-1$ & 0.60 & 1.96 & 0.06 & 0.17 & 0.41 \\
Year $t-2$ & 0.61 & 1.99 & 0.07 & 0.18 & 0.41 \\
Year $t-3$ & 0.69 & 2.18 & 0.07 & 0.17 & 0.43 \\
& & & & & & & \\
\hline
\end{tabular}

Panel C: EPS change and discretionary accruals (sorted by quintiles of EPS change)

\begin{tabular}{|c|c|c|c|c|c|}
\hline & Lower (1) & $(2)$ & (3) & $(4)$ & Upper (5) \\
\hline EPS change & 0.02 & 0.08 & 0.17 & 0.33 & 0.95 \\
\hline EPS change $(\%)$ & 7.10 & 13.70 & 21.30 & 32.50 & 58.20 \\
\hline Discretionary accruals & 0.013 & 0.011 & 0.011 & 0.004 & 0.002 \\
\hline Discretionary accruals per share & 0.02 & 0.06 & 0.09 & 0.05 & 0.02 \\
\hline
\end{tabular}

\section{Notes to Table 3}

Table 3 reports summary data of the year-on-year change in EPS for the earnings string firms. Panel A reports the frequency distribution of the change in EPS (\%) in each of the last three years of the earnings string period and the earnings break year. Loss firms refer to earnings string firms that report a negative EPS in the current year or the previous year. Panel B provides descriptive statistics of the magnitude of the EPS change (in dollars). Panel C provides descriptive statistics of the median values of the magnitude of the EPS change and the corresponding discretionary accruals sorted by quintiles based on the change in EPS in the last year of the earnings string period. See appendix for variable definitions.

* The magnitudes of EPS change in year $t$ are EPS decreases and the magnitudes of EPS change in year $t-1$ to $t-3$ are EPS increases. Year $t$ refers to the year of the earnings string break. Years $t-1, t-2$ and $t-3$ refer to the last, second last and third last year of the earnings string periods respectively. 
Table 4 reports descriptive statistics and time-series analysis for the earnings management measures. I report the firm-year observations of earnings string firms three years before the break in their earnings string pattern $(t-3)$ and compare these to the firm-year observations of the same firms one year prior to the break in the earnings string $(t-1)$. I examine whether there is an over-time increase in the earnings management measures to assess whether the univariate results are consistent with my hypothesis that there is higher income-increasing earnings management as earnings string firms near the end of their earnings string periods.

Mean (median) discretionary accruals for the first earnings string sample are -0.5 percent $(-0.6$ percent $)$ of total assets in year $t-3$ but increase to 1.8 percent ( 0.9 percent $)$ in year $t-1$. This is also a recurring pattern for the second and third earnings string samples. Mean (median) discretionary accruals for the second earnings string sample are -1.1 percent (-0.9 percent) of total assets in year $t-3$ and increase to 1.4 percent ( 0.8 percent) in year $t-1$. The mean (median) discretionary accruals for the third earnings string sample are -1.1 percent (-0.7 percent) of total assets in year $t-3$ and rise to 0.8 percent ( 0.7 percent) in year $t-1$. The over-time changes are statistically significant at the 0.01 level. Performance-adjusted and performance-matched discretionary accruals show similar over-time increases (significant at the 0.01 level) as firms move closer toward their earnings breaks.

Next, I examine whether the NOA and WCNOA ratios increase as firms move closer to their earnings breaks. Unlike the discretionary accruals measures, the patterns in the over-time changes in these ratios vary across the three earnings string samples. This may be expected, 
however, as the NOA ratio and WCNOA ratio are also functions of real actions such as operating and investing decisions. With some exceptions, NOA and industry adjusted NOA ratios tend to decrease as earnings string firms move from year $t-3$ to year $t-1 .{ }^{3}$ In contrast, the WCNOA and industry adjusted WCNOA ratios tend to increase (or stay the same) as earnings string firms reach the end of their increasing earnings patterns, consistent with hypothesis 2 . The exception is the overtime change in WCNOA ratio for the third earnings string sample which decreases between year $t-3$ and $t-1$.

${ }^{3}$ Barton and Simko (2002) note that reported sales also reflects managers' biased implementation of GAAP. Thus, an over-time decrease in a firm's reported NOA ratio might be due to managers manipulating reported sales in greater proportion to other income/expense items. 
Table 4: Time-series Analysis - Earnings Management Variables

\begin{tabular}{|c|c|c|c|c|}
\hline \multirow[b]{2}{*}{ First earnings string sample } & \multicolumn{2}{|c|}{$\underline{\text { Year } t-3}$} & \multicolumn{2}{|c|}{$\underline{\text { Year } t-2}$} \\
\hline & $\underline{\text { Mean }}$ & $\underline{\text { Median }}$ & $\underline{\text { Mean }}$ & $\underline{\text { Median }}$ \\
\hline Discretionary accruals & -0.005 & -0.006 & 0.003 & -0.002 \\
\hline Performance adjusted DA & -0.006 & -0.007 & 0.001 & -0.003 \\
\hline Performance matched DA & -0.007 & -0.007 & -0.005 & -0.004 \\
\hline NOA ratio & 0.868 & 0.472 & 0.829 & 0.465 \\
\hline WCNOA ratio & 0.157 & 0.152 & 0.156 & 0.151 \\
\hline Industry adjusted NOA ratio & 0.255 & -0.025 & 0.224 & -0.027 \\
\hline Industry adjusted WCNOA ratio & 0.003 & -0.006 & 0.003 & -0.005 \\
\hline \multicolumn{5}{|l|}{ Second earnings string sample } \\
\hline Discretionary accruals & -0.011 & -0.009 & -0.002 & -0.002 \\
\hline Performance adjusted DA & -0.011 & -0.008 & -0.005 & -0.004 \\
\hline Performance matched DA & -0.016 & -0.009 & -0.014 & -0.008 \\
\hline NOA ratio & 0.634 & 0.477 & 0.599 & 0.460 \\
\hline WCNOA ratio & 0.175 & 0.167 & 0.168 & 0.162 \\
\hline Industry adjusted NOA ratio & 0.056 & -0.012 & 0.027 & -0.024 \\
\hline Industry adjusted WCNOA ratio & 0.009 & 0.000 & 0.004 & -0.001 \\
\hline \multicolumn{5}{|l|}{ Third earnings string sample } \\
\hline Discretionary accruals & -0.011 & -0.007 & -0.005 & -0.006 \\
\hline Performance adjusted DA & -0.010 & -0.007 & -0.007 & -0.007 \\
\hline Performance matched DA & -0.018 & -0.015 & -0.014 & -0.004 \\
\hline NOA ratio & 0.569 & 0.471 & 0.545 & 0.458 \\
\hline WCNOA ratio & 0.168 & 0.163 & 0.161 & 0.155 \\
\hline Industry adjusted NOA ratio & 0.012 & -0.016 & -0.010 & -0.031 \\
\hline Industry adjusted WCNOA ratio & 0.005 & -0.006 & 0.000 & -0.010 \\
\hline
\end{tabular}




\section{Table 4 (Continued)}

\begin{tabular}{|c|c|c|c|c|}
\hline \multirow[b]{2}{*}{ First earnings string sample } & \multicolumn{2}{|c|}{$\underline{\text { Year } t-1}$} & \multicolumn{2}{|c|}{ Differences } \\
\hline & $\underline{\text { Mean }}$ & $\underline{\text { Median }}$ & $\underline{\text { Mean }}$ & $\underline{\text { Median }}$ \\
\hline Discretionary accruals & 0.018 & 0.009 & $0.023^{* * *}$ & $0.015^{* * *}$ \\
\hline Performance adjusted DA & 0.012 & 0.005 & $0.019^{* * *}$ & $0.012^{* * *}$ \\
\hline Performance matched DA & 0.009 & 0.008 & $0.016^{* * *}$ & $0.015^{* * *}$ \\
\hline NOA ratio & 0.809 & 0.487 & $-0.059^{* * *}$ & 0.015 \\
\hline WCNOA ratio & 0.164 & 0.156 & $0.007^{* * *}$ & $0.003^{* * *}$ \\
\hline Industry adjusted NOA ratio & 0.204 & -0.012 & $-0.051^{* * *}$ & $0.013^{*}$ \\
\hline Industry adjusted WCNOA ratio & 0.018 & 0.009 & $0.023^{* * *}$ & $0.015^{* * *}$ \\
\hline \multicolumn{5}{|l|}{ Second earnings string sample } \\
\hline Discretionary accruals & 0.014 & 0.008 & $0.025^{* * *}$ & $0.017^{* * *}$ \\
\hline Performance adjusted DA & 0.009 & 0.006 & $0.020^{* * *}$ & $0.014^{* * *}$ \\
\hline Performance matched DA & 0.006 & 0.006 & $0.022^{* * *}$ & $0.014^{* * *}$ \\
\hline NOA ratio & 0.617 & 0.472 & -0.017 & $-0.004^{* * *}$ \\
\hline WCNOA ratio & 0.172 & 0.165 & -0.002 & -0.002 \\
\hline Industry adjusted NOA ratio & 0.044 & -0.018 & -0.012 & $-0.006^{* *}$ \\
\hline Industry adjusted WCNOA ratio & 0.010 & 0.000 & 0.001 & 0.000 \\
\hline \multicolumn{5}{|l|}{ Third earnings string sample } \\
\hline Discretionary accruals & 0.008 & 0.007 & $0.018^{* * *}$ & $0.013^{* * *}$ \\
\hline Performance adjusted DA & 0.005 & 0.004 & $0.014^{* * *}$ & $0.010^{* * *}$ \\
\hline Performance matched DA & -0.003 & 0.007 & $0.015^{* * *}$ & $0.021^{* * *}$ \\
\hline NOA ratio & 0.544 & 0.464 & $-0.024^{* * *}$ & $-0.007^{* * *}$ \\
\hline WCNOA ratio & 0.163 & 0.158 & $-0.006^{* * *}$ & $-0.005^{* *}$ \\
\hline Industry adjusted NOA ratio & -0.013 & -0.028 & $-0.025^{* * *}$ & $-0.012^{* * *}$ \\
\hline Industry adjusted WCNOA ratio & 0.004 & -0.002 & -0.001 & 0.004 \\
\hline
\end{tabular}

\section{Notes to Table 4}

Table 4 reports summary data for earnings string firms in each of the three years $(t-1, t-2, t-3)$ preceding the break in their earnings string pattern. ${ }^{* * * * *} /^{*}$ denotes significance levels at the $1 \%, 5 \%$ and $10 \%$ level (two-tailed) respectively based on t-tests for mean differences and Wilcoxon tests for median differences. See appendix for variable definitions. 
Table 5 reports Pearson and Spearman rank correlations for the dependent and independent variables. As predicted, the correlations between discretionary accruals and NOA ratio (WCNOA ratio) are positive and generally statistically significant at the 0.05 level or better. The exception is the Pearson correlation between discretionary accruals and industry-adjusted NOA ratio, significant at the 0.17 level. The correlation between discretionary accruals and WCNOA ratio is higher than the correlation between discretionary accruals and NOA ratio. For example, the Pearson and Spearman correlations between discretionary accruals and NOA ratio are $0.01(\mathrm{p}<0.10)$ and $0.16(\mathrm{p}<0.001)$ respectively, and the Pearson and Spearman correlations between discretionary accruals and WCNOA ratio are $0.29(\mathrm{p}<0.001)$ and $0.30(\mathrm{p}<0.001)$ respectively. Based on these correlations, I expect to see firms engaging in income-increasing earnings management to report higher NOA and WCNOA ratios and I expect the association to be stronger for WCNOA ratios than for NOA ratios.

With respect to the control variables, the Pearson correlations between discretionary accruals and LEVERAGE $(\mathrm{r}=0.11, \mathrm{p}<0.001)$ and between discretionary accruals and GROWTH $(\mathrm{r}=0.15, \mathrm{p}<0.001)$ are positive as predicted. Similar results are obtained for the Spearman correlations. The Pearson and Spearman correlations between NOA (WCNOA) ratio and LEVERAGE are also positive and significant at the 0.01 level, suggesting that as firms take on more debt, they become less asset-efficient. The correlation coefficients between NOA ratio and GROWTH are mixed; the Pearson correlation is insignificant whereas the Spearman correlation is 
negative $(\mathrm{r}=-0.05, \mathrm{p}<0.001)$. As with the NOA ratios, the correlations between WCNOA ratio and GROWTH have different signs but the magnitudes of the correlations are small.

The results are mixed with respect to the sign and significance of the correlations of SIZE and FIRM AGE with the earnings management constraint variables. Hence, I do not have predicted directions for the coefficients of SIZE and FIRM AGE in my multivariate tests. 


\section{Table 5: Correlation Matrix}

\section{Panel A: Pearson Correlation}

\begin{tabular}{|c|c|c|c|c|c|c|c|c|c|c|}
\hline & 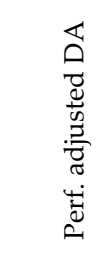 & 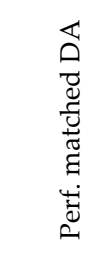 & 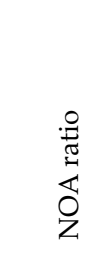 & 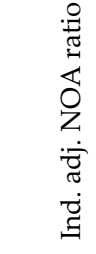 & 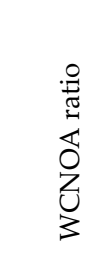 & 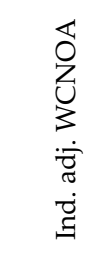 & $\begin{array}{l}\stackrel{ }{N} \\
\text { ऊ }\end{array}$ & 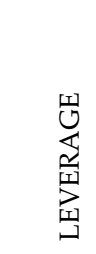 & $\begin{array}{l}\mathbb{I} \\
\stackrel{1}{3} \\
0 \\
0 \\
0\end{array}$ & 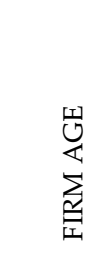 \\
\hline \multirow[t]{2}{*}{ Discretionary accruals } & 0.959 & 0.635 & 0.009 & 0.006 & 0.294 & 0.342 & 0.008 & 0.107 & 0.148 & -0.011 \\
\hline & $<.0001$ & $<.0001$ & 0.0564 & 0.1747 & $<.0001$ & $<.0001$ & 0.1015 & $<.0001$ & $<.0001$ & 0.0219 \\
\hline \multirow[t]{2}{*}{ Perf. adj. DA } & & 0.614 & 0.019 & 0.018 & 0.287 & 0.338 & 0.002 & 0.135 & 0.122 & -0.014 \\
\hline & & $<.0001$ & $<.0001$ & 0.0002 & $<.0001$ & $<.0001$ & 0.6371 & $<.0001$ & $<.0001$ & 0.0002 \\
\hline \multirow[t]{2}{*}{ Perf. matched DA } & & & 0.037 & 0.036 & 0.182 & 0.231 & 0.011 & 0.091 & 0.063 & -0.005 \\
\hline & & & $<.0001$ & $<.0001$ & $<.0001$ & $<.0001$ & 0.0192 & $<.0001$ & $<.0001$ & 0.2395 \\
\hline \multirow[t]{2}{*}{ NOA ratio } & & & & 0.941 & -0.015 & 0.086 & 0.003 & 0.106 & 0.005 & -0.099 \\
\hline & & & & $<.0001$ & 0.0020 & $<.0001$ & 0.4846 & $<.0001$ & 0.2678 & $<.0001$ \\
\hline \multirow[t]{2}{*}{ Ind. adj. NOA ratio } & & & & & 0.047 & 0.092 & -0.025 & 0.063 & 0.007 & -0.094 \\
\hline & & & & & $<.0001$ & $<.0001$ & $<.0001$ & $<.0001$ & 0.1327 & $<.0001$ \\
\hline \multirow[t]{2}{*}{ WCNOA ratio } & & & & & & 0.832 & -0.157 & 0.071 & 0.012 & 0.015 \\
\hline & & & & & & $<.0001$ & $<.0001$ & $<.0001$ & 0.0105 & 0.0015 \\
\hline \multirow[t]{2}{*}{ Ind. adj. WCNOA ratio } & & & & & & & -0.062 & 0.153 & 0.027 & 0.005 \\
\hline & & & & & & & $<.0001$ & $<.0001$ & $<.0001$ & 0.3282 \\
\hline \multirow[t]{2}{*}{ SIZE } & & & & & & & & 0.156 & -0.029 & 0.453 \\
\hline & & & & & & & & $<.0001$ & $<.0001$ & $<.0001$ \\
\hline \multirow[t]{2}{*}{ LEVERAGE } & & & & & & & & & -0.084 & 0.040 \\
\hline & & & & & & & & & $<.0001$ & $<.0001$ \\
\hline \multirow[t]{2}{*}{ GROWTH } & & & & & & & & & & -0.247 \\
\hline & & & & & & & & & & $<.0001$ \\
\hline
\end{tabular}




\section{Table 5 (Continued)}

Panel B: Spearman Correlation

\begin{tabular}{|c|c|c|c|c|c|c|c|c|c|c|}
\hline & $\overleftrightarrow{\mathrm{a}}$ & 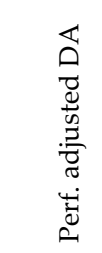 & 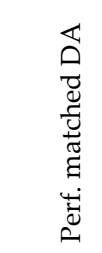 & 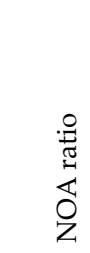 & 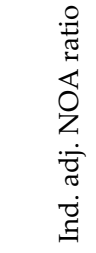 & 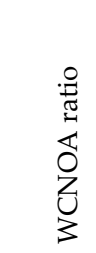 & 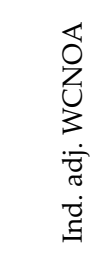 & $\begin{array}{l}\mathrm{N} \\
\text { సै }\end{array}$ & 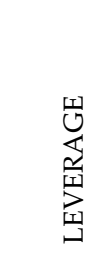 & $\begin{array}{l}\frac{1}{5} \\
3 \\
0 \\
\frac{1}{3} \\
0\end{array}$ \\
\hline \multirow[t]{2}{*}{ Perf. adj. DA } & 0.952 & & & & & & & & & \\
\hline & $<.0001$ & & & & & & & & & \\
\hline \multirow[t]{2}{*}{ Perf. matched DA } & 0.592 & 0.578 & & & & & & & & \\
\hline & $<.0001$ & $<.0001$ & & & & & & & & \\
\hline \multirow[t]{2}{*}{ NOA ratio } & 0.155 & 0.167 & 0.123 & & & & & & & \\
\hline & $<.0001$ & $<.0001$ & $<.0001$ & & & & & & & \\
\hline \multirow[t]{2}{*}{ Ind. adj. NOA ratio } & 0.166 & 0.177 & 0.131 & 0.699 & & & & & & \\
\hline & $<.0001$ & $<.0001$ & $<.0001$ & $<.0001$ & & & & & & \\
\hline \multirow[t]{2}{*}{ WCNOA ratio } & 0.300 & 0.285 & 0.184 & 0.242 & 0.293 & & & & & \\
\hline & $<.0001$ & $<.0001$ & $<.0001$ & $<.0001$ & $<.0001$ & & & & & \\
\hline \multirow[t]{2}{*}{ Ind. adj. WCNOA ratio } & 0.397 & 0.389 & 0.263 & 0.334 & 0.360 & 0.704 & & & & \\
\hline & $<.0001$ & $<.0001$ & $<.0001$ & $<.0001$ & $<.0001$ & $<.0001$ & & & & \\
\hline \multirow[t]{2}{*}{ SIZE } & 0.015 & 0.009 & 0.017 & 0.150 & 0.115 & -0.172 & -0.053 & & & \\
\hline & 0.0011 & 0.0554 & $<.0001$ & $<.0001$ & $<.0001$ & $<.0001$ & $<.0001$ & & & \\
\hline \multirow[t]{2}{*}{ LEVERAGE } & 0.010 & 0.137 & 0.086 & 0.323 & 0.293 & 0.083 & 0.182 & 0.173 & & \\
\hline & $<.0001$ & $<.0001$ & $<.0001$ & $<.0001$ & $<.0001$ & $<.0001$ & $<.0001$ & $<.0001$ & & \\
\hline \multirow[t]{2}{*}{ GROWTH } & 0.154 & 0.111 & 0.068 & -0.047 & -0.030 & -0.021 & -0.020 & -0.014 & -0.083 & \\
\hline & $<.0001$ & $<.0001$ & $<.0001$ & $<.0001$ & $<.0001$ & $<.0001$ & $<.0001$ & 0.0026 & $<.0001$ & \\
\hline \multirow[t]{2}{*}{ FIRM AGE } & -0.001 & -0.004 & -0.001 & -0.011 & -0.017 & 0.019 & 0.012 & 0.461 & 0.072 & -0.229 \\
\hline & 0.8187 & 0.3679 & 0.7968 & 0.0213 & 0.0002 & $<.0001$ & 0.0115 & $<.0001$ & $<.0001$ & $<.0001$ \\
\hline
\end{tabular}

Notes to Table 5

Table 5 reports Pearson and Spearman correlations for the full earnings string sample of 47,780 firm-year observations over 1952-2005. See appendix for variable definitions. 


\subsection{Earnings management tests}

\subsubsection{Main results}

Table 6 reports the regression results for the earnings management model as described in equation (1). I run both a single pooled regression as well as Fama-MacBeth regressions with each earnings string sample (described in section 5.1) as my treatment sample, and non-earnings string Compustat firm-year observations excluding banks and utilities between 1951-2006 as the benchmark sample. The t-statistics for the pooled regressions are adjusted for autocorrelation and heteroskedasticity using Newey-West standard errors since the same firm enters the regression more than once. The Fama-MacBeth approach requires running separate annual cross-sectional regressions. It is an alternative estimation approach to address the problem of correlated residuals due to having multiple observations of the same firm in my pooled regression. I report mean coefficient estimates by averaging the coefficients of the annual regressions. t-statistics for the Fama-MacBeth regressions are calculated using the standard error of the mean coefficient estimates across years.

My earnings management hypothesis (H1) predicts that earnings string firms will engage in income-increasing earnings management in the last two years of their earnings string period. The regression results show that earnings string firms engage in income-increasing earnings management in the last year of their earnings string period (year $t-1$ ) compared to the Compustat population across all three earnings string samples. 
Specifically, the coefficient for PREBREAK1 is 0.024 (t-statistic: $14.23, \mathrm{p}<0.001), 0.019$ (tstatistic: $9.42, \mathrm{p}<0.001$ ) and 0.012 (t-statistic: $4.75, \mathrm{p}<0.001$ ) for the first, second and third earnings string samples respectively based on pooled regression results using discretionary accruals as the dependent variable. The coefficients on PREBREAK1 suggest that discretionary accruals for earnings string firms in the last year of their earnings string period are approximately 1-3 percent of total assets higher than discretionary accruals for the average Compustat firm. I interpret these results as indicating that earnings string firms bias earnings upwards in the last year of their earnings string period.

Using performance adjusted discretionary accruals instead of discretionary accruals yields lower coefficient estimates, but the results remain statistically significant. Specifically, for the pooled regression tests with performance adjusted discretionary accruals as the dependent variable, the coefficient for PREBREAK1 is 0.020 (t-statistic: 12.68, $\mathrm{p}<0.001$ ), 0.015 (t-statistic: 8.23, $\mathrm{p}<0.001$ ) and 0.010 (t-statistic: 4.36, $\mathrm{p}<0.001$ ) for the first, second and third earnings string samples respectively.

I obtain similar results when I run separate-year Fama MacBeth regressions instead of a single pooled regression with either discretionary accruals or performance adjusted discretionary accruals as the dependent variable. As with the pooled regression results, I find that firms in all three earnings string samples manage earnings upwards by 1-2 percent of total assets in the last year of the earnings string period, significant at the 0.01 level. 
The regression results show mixed evidence of income-increasing earnings management in the second last year of the earnings string period (year $t-2$ ). There is some evidence of incomeincreasing earnings management in year $t-2$ for the first earnings string sample. Specifically, for the pooled regression results, the coefficient for PREBREAK2 is 0.9 percent ( 0.8 percent) using discretionary accruals (performance adjusted discretionary accruals) as the dependent variable, significant at the 0.01 level. However, in the Fama-MacBeth regression results for this sample, the coefficient for PREBREAK2 is 0.3 percent (t-statistic: 1.61) using discretionary accruals as the dependent variable and 0.4 percent ( $\mathrm{t}$-statistic: $2.29, \mathrm{p}<0.05)$ using performance-adjusted discretionary accruals as the dependent variable.

There is also mixed evidence of income-increasing earnings management in the second last year of the earnings string period for the second earnings string sample. The pooled regressions results show discretionary accruals for the earnings string firms are 0.4 percent higher (t-statistic: $2.22, \mathrm{p}<0.05)$ than discretionary accruals of the average Compustat firm in year $t-2$. However, the results do not hold when I use performance adjusted discretionary accruals or when I run the Fama-MacBeth regressions on this sample. Finally, there is no evidence of incomeincreasing earnings management in the second last year of the earnings string period for the third earnings string sample.

I interpret the results in my regression tests as follows. It appears that firms systematically manage earnings upwards in the last year of the earnings string period, but earnings management is smaller in magnitude and less pervasive in year $t-2$. The results are 
consistent with the view that firms experience increasing difficulty reporting higher earnings as they reach the end of their earnings string periods.

There is little evidence of income-increasing earnings management in the other years in the earnings string periods. The coefficients for PREBREAK3 and BEGSTRING are generally not significantly positive across all earnings string samples based on the various regression specifications I used. The only exception is the coefficient for BEGSTRING in the first earnings string sample in the pooled regression results. The coefficient for BEGSTRING is 0.6 percent (tstatistic: $3.72, \mathrm{p}<0.001$ ) using discretionary accruals and 0.4 percent (t-statistic: $2.69, \mathrm{p}<0.001$ ) using performance adjusted discretionary accruals. These results suggest that there is no systematic evidence of income-increasing earnings management throughout the earnings string period, with the exception of firms reporting their first earnings strings. However, the magnitude of incomeincreasing earnings management in the earlier years of the first earnings string period is small in relation to the last two years of their earnings string periods, consistent with my first hypothesis.

With respect to the control variables, the coefficient on LEVERAGE is positive, consistent with the debt hypothesis on earnings management. The coefficient on GROWTH is positive suggesting that the high growth firms in my sample manage earnings more than low growth firms. The coefficients on FIRM AGE and SIZE are generally positive, suggesting that bigger and older firms manage earnings to avoid an earnings decrease more than smaller and younger firms. 
Table 6: Earnings Management Regressions - Main Results

\begin{tabular}{|c|c|c|c|c|c|}
\hline Variables & Pred. sign & Coef. Est & t-statistics & Coef. Est & t-statistics \\
\hline & & $\underline{\text { Model } 1}$ & & $\underline{\text { Model } 2}$ & \\
\hline \multicolumn{6}{|l|}{$\underline{\text { Pooled sample regressions }}$} \\
\hline PREBREAK1 & + & 0.024 & $14.23^{* * *}$ & 0.020 & $12.68^{* * *}$ \\
\hline PREBREAK2 & + & 0.009 & $5.35^{* * *}$ & 0.008 & $5.17^{* * *}$ \\
\hline PREBREAK3 & $?$ & 0.003 & 1.57 & 0.004 & $2.11^{* *}$ \\
\hline BEGSTRING & $?$ & 0.006 & $3.72^{* * *}$ & 0.004 & $2.69^{* * *}$ \\
\hline SIZE & $?$ & 0.000 & $2.34^{* * *}$ & -0.000 & -0.01 \\
\hline LEVERAGE & + & 0.063 & $31.93^{* * *}$ & 0.065 & $35.72^{* * *}$ \\
\hline GROWTH & + & 0.053 & $33.05^{* * *}$ & 0.045 & $31.26^{* * *}$ \\
\hline FIRM AGE & $?$ & 0.005 & $10.39^{* * *}$ & 0.005 & $9.83^{* * *}$ \\
\hline Number of observations & & 131,576 & & 131,499 & \\
\hline $\operatorname{Adj} R^{2}$ & & 0.030 & & 0.027 & \\
\hline \multicolumn{6}{|l|}{$\underline{\text { Separate-year regressions }}$} \\
\hline PREBREAK1 & + & 0.017 & $7.41^{* * *}$ & 0.016 & $6.33^{* * *}$ \\
\hline PREBREAK2 & + & 0.003 & 1.61 & 0.004 & $2.29^{* *}$ \\
\hline PREBREAK3 & $?$ & -0.003 & $-2.01^{* *}$ & -0.002 & -0.95 \\
\hline BEGSTRING & $?$ & 0.000 & 0.09 & 0.000 & 0.12 \\
\hline SIZE & $?$ & 0.003 & 1.29 & 0.003 & 1.06 \\
\hline LEVERAGE & + & 0.053 & $13.13^{* * *}$ & 0.058 & $12.89^{* * *}$ \\
\hline GROWTH & + & 0.068 & $10.91^{* * *}$ & 0.051 & $11.53^{* * *}$ \\
\hline FIRM AGE & $?$ & 0.004 & $4.76^{* * *}$ & 0.004 & $5.61^{* * *}$ \\
\hline Number of years & & 49 & & 49 & \\
\hline Mean adj. $\mathrm{R}^{2}$ & & 0.027 & & 0.025 & \\
\hline
\end{tabular}


'Table 6 (Continued)

Panel B: Second earnings string sample

\begin{tabular}{|c|c|c|c|c|c|}
\hline Variables & Pred. sign & Coef. Est & t-statistics & Coef. Est & t-statistics \\
\hline & & $\underline{\text { Model } 1}$ & & $\underline{\text { Model } 2}$ & \\
\hline \multicolumn{6}{|l|}{ Pooled sample regressions } \\
\hline PREBREAK1 & + & 0.019 & $9.42^{* * *}$ & 0.015 & $8.23^{* * *}$ \\
\hline PREBREAK2 & + & 0.004 & $2.22^{* *}$ & 0.002 & 1.33 \\
\hline PREBREAK3 & $?$ & -0.001 & -0.62 & 0.000 & 0.00 \\
\hline BEGSTRING & $?$ & -0.001 & -1.01 & -0.002 & -1.44 \\
\hline SIZE & $?$ & 0.000 & $2.48^{* *}$ & 0.000 & 0.34 \\
\hline LEVERAGE & + & 0.061 & $30.08^{* * *}$ & 0.063 & $33.59^{* * *}$ \\
\hline GROWTH & + & 0.052 & $30.52^{* * *}$ & 0.044 & $28.92^{* * *}$ \\
\hline FIRM AGE & $?$ & 0.005 & $9.98^{* * *}$ & 0.005 & $9.64^{* * *}$ \\
\hline Number of observations & & 120,113 & & 120,044 & \\
\hline Adj $R^{2}$ & & 0.026 & & 0.025 & \\
\hline \multicolumn{6}{|l|}{ Separate-year regressions } \\
\hline PREBREAK1 & + & 0.012 & $5.02^{* * *}$ & 0.010 & $4.68^{* * *}$ \\
\hline PREBREAK2 & + & 0.001 & 0.62 & 0.001 & 0.37 \\
\hline PREBREAK3 & $?$ & -0.003 & -1.44 & -0.002 & -0.88 \\
\hline BEGSTRING & $?$ & -0.004 & $-2.85^{* * *}$ & -0.004 & $-2.59^{* *}$ \\
\hline SIZE & $?$ & 0.001 & $2.65^{* * *}$ & 0.000 & 1.00 \\
\hline LEVERAGE & + & 0.055 & $12.77^{* * *}$ & 0.061 & $13.57^{* * *}$ \\
\hline GROWTH & + & 0.072 & $11.46^{* * *}$ & 0.054 & $11.48^{* * *}$ \\
\hline FIRM AGE & $?$ & 0.004 & $4.78^{* * *}$ & 0.004 & $5.66^{* * *}$ \\
\hline Number of years & & 46 & & 46 & \\
\hline Mean adj. $\mathrm{R}^{2}$ & & 0.025 & & 0.024 & \\
\hline
\end{tabular}




\section{Table 6 (Continued)}

Panel C: Third earnings string sample

\begin{tabular}{|c|c|c|c|c|c|}
\hline Variables & Pred. sign & Coef. Est & t-statistics & Coef. Est & t-statistics \\
\hline & & Model 1 & & Model 2 & \\
\hline \multicolumn{6}{|l|}{$\underline{\text { Pooled sample regressions }}$} \\
\hline PREBREAK1 & + & 0.012 & $4.75^{* * *}$ & 0.010 & $4.36^{* * *}$ \\
\hline PREBREAK2 & + & 0.000 & 0.03 & 0.000 & 0.12 \\
\hline PREBREAK3 & $?$ & -0.002 & -0.86 & -0.000 & -0.17 \\
\hline BEGSTRING & $?$ & -0.002 & -1.03 & -0.001 & -0.52 \\
\hline SIZE & $?$ & 0.000 & $2.68^{* * *}$ & 0.000 & 0.70 \\
\hline LEVERAGE & + & 0.060 & $28.56^{* * *}$ & 0.061 & $31.69^{* * *}$ \\
\hline GROWTH & + & 0.051 & $29.84^{* * *}$ & 0.043 & $28.37^{* * *}$ \\
\hline FIRM AGE & $?$ & 0.005 & $9.65^{* * *}$ & 0.005 & $9.36^{* * *}$ \\
\hline Number of observations & & 114,249 & & 114,181 & \\
\hline Adj $R^{2}$ & & 0.025 & & 0.024 & \\
\hline \multicolumn{6}{|l|}{ Separate-year regressions } \\
\hline PREBREAK1 & + & 0.012 & $3.77^{* * *}$ & 0.012 & $3.60^{* * *}$ \\
\hline PREBREAK2 & + & -0.001 & -0.27 & 0.000 & 0.08 \\
\hline PREBREAK3 & $?$ & -0.001 & -0.38 & 0.001 & 0.43 \\
\hline BEGSTRING & $?$ & -0.002 & -0.77 & -0.001 & -0.25 \\
\hline SIZE & $?$ & 0.002 & $3.90^{* * *}$ & 0.001 & $2.38^{* *}$ \\
\hline LEVERAGE & + & 0.056 & $13.98^{* * *}$ & 0.061 & $14.93^{* * *}$ \\
\hline GROWTH & + & 0.075 & $11.99^{* * *}$ & 0.056 & $12.01^{* * *}$ \\
\hline FIRM AGE & $?$ & 0.004 & $4.47^{* * *}$ & 0.004 & $5.40^{* * *}$ \\
\hline Number of years & & 44 & & 44 & \\
\hline Mean adj. $\mathrm{R}^{2}$ & & 0.024 & & 0.023 & \\
\hline
\end{tabular}

\section{Notes to Table 6}

Table 6 reports the results of both pooled and Fama-MacBeth regressions of the earnings management tests. Model 1 uses the modified Jones model discretionary accruals as the dependent variable. Model 2 uses the performance-adjusted modified Jones model discretionary accruals as the dependent variable. $t$ statistics for the pooled regressions are calculated using Newey-West standard errors corrected for autocorrelation and heteroskedasticity. t-statistics for the Fama-MacBeth regressions are calculated using the standard error of the mean coefficient estimates across years. The sample period for the regression tests spans 1952-2005. The first/second/third string sample comprises 6,130/2,540/1,132 earnings string firms as described in Table 1. The benchmark sample is the Compustat population between 1951-2006 (excluding banks and utilities and the earnings string sample). ${ }^{* * * * * *}$ denotes significance levels at the $1 \%, 5 \%$ and $10 \%$ level (two-tailed) respectively. See appendix for variable definitions. 


\subsubsection{Matched sample design}

Table 7 reports the results of my earnings management test using the matched sample design. This test uses performance matched discretionary accruals to measure earnings management. ${ }^{4}$ I run my earnings management model (equation 1 ) for each earnings string sample with performance-matched discretionary accruals as the dependent variable. I drop BEGSTRING from the regression to avoid perfect collinearity. The results are generally consistent with the results of my earnings management tests in Table 6.

Specifically, I find evidence of income-increasing earnings management in year $t-1$ for the first and second earnings string samples and mixed evidence for the third earnings string sample. The coefficients on PREBREAK1 are 0.019 (t-statistic: 6.41, p<0.001), 0.023 (t-statistic: 6.10, $\mathrm{p}<0.001$ ) and 0.007 (t-statistic: 1.36) for the first, second and third earnings string samples respectively using the pooled regressions. When I include firm-year observations for earnings string firms that report more than three earnings strings to the third earnings string sample $(1,892$ firms in total), the coefficient is 0.009 (t-statistic: 2.26, $\mathrm{p}<0.05)$ for PREBREAK1 (untabulated). Results based on Fama-MacBeth regressions are similar; the coefficients on PREBREAK1 are 0.023 (t-statistic: 6.53, p<0.001), 0.017 (t-statistic: 4.51, p<0.001) and 0.012 (t-statistic: 1.74, $\mathrm{p}<0.10$ ) for the first, second and third earnings string samples respectively using the Fama-MacBeth regressions.

\footnotetext{
${ }^{4}$ Kothari et al. (2005) show that performance-matched discretionary accruals are less biased by misspecification arising from the positive association between discretionary accruals and accounting performance.
} 
The results for PREBREAK2 are similar to the earnings management tests reported in Table 6. I find evidence of income-increasing earnings management in year $t-2$ for the first earnings string sample, but not for the second or third earnings string samples. Specifically, firms reporting their first earnings string have performance matched discretionary accruals that are 0.6 percent $(\mathrm{p}<0.05)$ higher than their matched firms based on both pooled and Fama-MacBeth regression results. I do not find evidence of earnings management three years preceding the earnings break (PREBREAK3) for any earnings string sample.

I interpret the results of my matched sample regressions to suggest that performancematched discretionary accruals are higher in the year preceding the earnings break for all earnings string samples. It appears that firms in the first earnings string sample (but not firms in the second or third earnings string samples) initiate income-increasing earnings management as early as the second last year of their earnings string period, similar to the results in Table 6.

Overall, the results provide further evidence of income-increasing earnings management when earnings string firms reach the end of their increasing earnings patterns. 
Table 7: Earnings Management Regressions - Matched Sample Design

\begin{tabular}{|c|c|c|c|c|c|}
\hline Variables & Pred. sign & Coef. Est & t-statistics & Coef. Est & t-statistics \\
\hline First earnings string sample & & $\underline{\text { Pooled }}$ & & $\underline{\text { Fama-MacBeth }}$ & \\
\hline PREBREAK1 & + & 0.019 & $6.41^{* * *}$ & 0.023 & $6.53^{* * *}$ \\
\hline PREBREAK2 & + & 0.006 & $1.95^{* *}$ & 0.006 & $2.21^{* *}$ \\
\hline PREBREAK3 & $?$ & 0.003 & 1.11 & 0.001 & 0.43 \\
\hline SIZE & $?$ & 0.000 & 0.61 & 0.001 & 1.42 \\
\hline LEVERAGE & + & 0.086 & $12.91^{* * *}$ & 0.080 & $10.25^{* * *}$ \\
\hline GROWTH & + & 0.035 & $7.41^{*}$ & 0.039 & $5.59^{* * *}$ \\
\hline FIRM AGE & $?$ & 0.003 & 1.73 & 0.003 & $1.75^{*}$ \\
\hline Number of observations & & 24,399 & & 46 & \\
\hline Adj $R^{2}$ & & 0.014 & & 0.014 & \\
\hline \multicolumn{6}{|l|}{ Second earnings string sample } \\
\hline PREBREAK1 & + & 0.023 & $6.10^{* * *}$ & 0.017 & $4.51^{* * *}$ \\
\hline PREBREAK2 & + & 0.002 & 0.64 & 0.001 & 0.14 \\
\hline PREBREAK3 & $?$ & 0.001 & 0.29 & -0.003 & -0.86 \\
\hline SIZE & $?$ & -0.001 & -1.63 & -0.002 & $-2.01^{* *}$ \\
\hline LEVERAGE & + & 0.114 & $11.51^{* * *}$ & 0.119 & $8.80^{* * *}$ \\
\hline GROWTH & + & 0.019 & $1.88^{*}$ & 0.027 & $2.49^{* *}$ \\
\hline FIRM AGE & $?$ & 0.004 & 1.07 & 0.004 & 0.59 \\
\hline Number of observations & & 10,986 & & 43 & \\
\hline Adj $R^{2}$ & & 0.019 & & 0.019 & \\
\hline
\end{tabular}




\section{Table 7 (Continued)}

\begin{tabular}{|c|c|c|c|c|c|}
\hline Variables & Pred. sign & Coef. Est & t-statistics & Coef. Est & t-statistics \\
\hline Third earnings string sampl & & $\underline{\text { Pooled }}$ & & Fama-MacBeth & \\
\hline PREBREAK1 & + & 0.007 & 1.36 & 0.012 & $1.74^{*}$ \\
\hline PREBREAK2 & + & -0.003 & -0.52 & -0.001 & -0.10 \\
\hline PREBREAK3 & $?$ & -0.006 & -1.05 & 0.001 & 0.14 \\
\hline SIZE & $?$ & -0.001 & -0.68 & -0.001 & -0.95 \\
\hline LEVERAGE & + & 0.090 & $5.86^{* * *}$ & 0.033 & 1.03 \\
\hline GROWTH & + & 0.040 & $2.72^{* * *}$ & 0.019 & 0.32 \\
\hline FIRM AGE & $?$ & 0.004 & 0.63 & 0.013 & 1.23 \\
\hline Number of observations & & 4,978 & & 43 & \\
\hline Adj $R^{2}$ & & 0.010 & & 0.008 & \\
\hline
\end{tabular}

\section{Notes to Table 7}

Table 7 reports the results of both pooled and Fama-MacBeth regressions using values based on a one-toone matched sample. A one-to-one match is obtained by matching each earnings string firm-year observation based on ROA to its closest non-earnings string firm-year observation in the same industry and year. Performance matched values are obtained by differencing the matched control firm's value from the sample firm's value as described in Kothari, Leone and Wasley (2005). The first string sample consists 24,399 matched firm-year observations over 1952-2005. The second string sample consists 10,986 matched firm-year observations over 1957-2005. The third string sample consists 4,978 matched firm-year observations over 1961-2005. t-statistics for the pooled regressions are calculated using Newey-West standard errors corrected for autocorrelation. t-statistics for the Fama-MacBeth regressions are calculated using the standard error of the mean coefficient estimates across years. ${ }^{* *} / * * *$ denotes significance levels at the $1 \%, 5 \%$ and $10 \%$ level (two-tailed) respectively. See appendix for variable definitions. 


\subsection{Earnings management constraint tests}

\subsubsection{Portfolio analysis}

My earnings management constraint tests examine whether firms lose the ability to maintain their earnings strings because they run out of accounting flexibility. I use the NOA ratio and WCNOA ratio as inverse measures of accounting flexibility. A high value indicates low accounting flexibility, reflecting the presumption that the firm has biased earnings upwards in previous periods.

I first test for the construct validity of NOA and WCNOA ratios. If these ratios are good proxies for accounting flexibility, they will be positively associated with previous years of income-increasing earning management. I form four separate sets of quintiles - by separately ranking all firms in my earnings string sample (10,562 observations) based on the magnitudes of their NOA ratios, WCNOA ratios, industry-adjusted NOA ratios and industry-adjusted WCNOA ratios. I use the ratios measured in the last year of the earnings string period. Thus, the first (last) quintile comprises earnings string firms that report the lowest (highest) level of operating assets ratios at the end of their earnings string period. For each earnings string firm, I obtain a firmspecific measure of cumulative income-increasing earnings management by summing the signed magnitudes of annual discretionary accruals of that firm from the first year of its earnings string period to the last year of its earnings string period. The cumulative discretionary accruals capture the cumulative effects of income-increasing earnings management for each earnings string firm. 
I obtain the mean value of each quintile's cumulative discretionary accruals by averaging all earnings string firms' cumulative discretionary accruals within each quintile. I test for a difference between quintile (1)'s and quintile (5)'s cumulative discretionary accruals using a $t$ test. Table 8 reports the results of this test. The results show that earnings string firms that report higher values of NOA (WCNOA) ratios have higher levels of cumulative discretionary accruals during their earnings string periods. The relation is monotonic for WCNOA ratios but not for NOA ratios. The quintile portfolio of firms with the highest NOA ratio (industry adjusted NOA ratio) reports cumulative discretionary accruals of 4.2 percent (6.6 percent) of total assets. In contrast, the quintile portfolio of firms with the lowest NOA ratio (industry adjusted NOA ratio) reports cumulative discretionary accruals of -12.0 percent (-10.2 percent) of total assets. The quintile portfolio of firms with the highest WCNOA ratio (industry adjusted WCNOA ratio) reports cumulative discretionary accruals of 18.2 percent (19.7 percent) of total assets versus -12.5 percent (-19.6 percent) of total assets for the quintile portfolio of firms with the lowest WCNOA ratio (industry adjusted WCNOA ratio). I obtain similar results if I use performance adjusted discretionary accruals or performance matched discretionary accruals instead of discretionary accruals. The differences between the highest quintiles and lowest quintiles are all statistically significant at the 0.01 level across all measures. Based on these results, I conclude that the NOA and WCNOA ratios have reasonable construct validity. 
Table 8: Portfolio Analysis - Accounting Flexibility and Earnings Management

\begin{tabular}{|c|c|c|c|c|c|c|}
\hline \multirow[b]{2}{*}{ Accumulated measures } & \multicolumn{6}{|c|}{ Quintiles of NOA ratio } \\
\hline & Lower (1) & $(2)$ & $(3)$ & $(4)$ & Upper (5) & Diff. (5-1) \\
\hline Discretionary accruals (DA) & -0.120 & -0.022 & 0.020 & 0.065 & 0.042 & $0.162^{* * *}$ \\
\hline Performance adjusted DA & -0.115 & -0.032 & 0.008 & 0.046 & 0.032 & $0.148^{* * *}$ \\
\hline \multirow[t]{3}{*}{ Performance matched DA } & -0.161 & -0.054 & -0.011 & 0.019 & 0.028 & $0.190^{* * *}$ \\
\hline & \multicolumn{6}{|c|}{ Quintiles of WCNOA ratio } \\
\hline & Lower (1) & $(2)$ & (3) & $(4)$ & Upper (5) & Diff. (5-1) \\
\hline Discretionary accruals (DA) & -0.125 & -0.089 & -0.027 & 0.037 & 0.182 & $0.307^{* * *}$ \\
\hline Performance adjusted DA & -0.117 & -0.086 & -0.032 & 0.021 & 0.149 & $0.266^{* * *}$ \\
\hline \multirow[t]{3}{*}{ Performance matched DA } & -0.131 & -0.117 & -0.058 & -0.006 & 0.129 & $0.261^{* * *}$ \\
\hline & \multicolumn{6}{|c|}{ Quintiles of industry adjusted NOA ratio } \\
\hline & Lower (1) & $(2)$ & $(3)$ & $(4)$ & Upper (5) & Diff. (5-1) \\
\hline Discretionary accruals (DA) & -0.102 & -0.047 & 0.010 & 0.057 & 0.066 & $0.168^{* * *}$ \\
\hline Performance adjusted DA & -0.098 & -0.056 & 0.000 & 0.038 & 0.055 & $0.154^{* * *}$ \\
\hline \multirow[t]{3}{*}{ Performance matched DA } & -0.129 & -0.094 & -0.028 & 0.024 & 0.049 & $0.177^{* * *}$ \\
\hline & \multicolumn{6}{|c|}{ Quintiles of industry adjusted WCNOA ratio } \\
\hline & Lower (1) & $(2)$ & (3) & $(4)$ & Upper (5) & Diff. (5-1) \\
\hline Discretionary accruals (DA) & -0.196 & -0.074 & -0.014 & 0.065 & 0.197 & $0.394^{* * *}$ \\
\hline Performance adjusted DA & -0.183 & -0.075 & -0.019 & 0.048 & 0.164 & $0.347^{* * *}$ \\
\hline Performance matched DA & -0.224 & -0.113 & -0.045 & 0.040 & 0.160 & $0.384^{* * *}$ \\
\hline
\end{tabular}

\section{Notes to Table 8}

Table 8 reports the mean levels of discretionary accruals, performance adjusted discretionary accruals and performance matched discretionary accruals for the full earnings string sample of 10,562 earnings strings accumulated over their earnings string periods. Firms are sorted separately into quintiles, ranked by four measures separately - NOA ratio, WCNOA ratio, industry adjusted NOA ratio and industry adjusted WCNOA ratio measured at the end of their earnings string period (year $t-1$ ). ${ }^{* *} / * * / *$ denotes significance levels at the $1 \%, 5 \%$ and $10 \%$ level (two-tailed) respectively based on t-tests of differences between quintile 5 and quintile 1 . See appendix for variable definitions. 


\subsubsection{Trend analysis}

I test whether there is an upward trend in my earnings management and earnings management constraint variables during the earnings string period. Finding an upward trend in these measures is consistent with my second hypothesis that earnings string firms have reduced levels of accounting flexibility as they reach the end of their earnings strings, presumably because they have engaged in income-increasing earnings management during the earnings string period.

I regress discretionary accruals on TREND, measured as the proximity of the earnings string firm-year observation to the end of an earnings string period. Firm-year observations in the last year of the earnings string period are assigned the highest value and firm-year observations furthest from the end of the earnings string period are assigned the lowest value. I also run trend regressions separately using NOA (WCNOA) ratios as dependent variables.

Panel A of Table 9 reports the results of the trend regressions using the sample of all earnings string firms between 1952-2005. Discretionary accruals trend upwards by 0.1 percent (tstatistic: $10.88, \mathrm{p}<0.001)$ for each year the earnings string firm is closer to the break in the earnings string pattern. I obtain similar results with both performance adjusted and performance matched discretionary accruals. The trend regressions also show that NOA ratios and WCNOA ratios increase as earnings string firms are closer to the end of their earnings string periods. Specifically, the NOA ratio (industry-adjusted NOA ratio) trends upwards by $0.015(0.009)$, significant at the 0.01 level, whereas the WCNOA ratio (industry-adjusted WCNOA ratio) trends upwards by 0.001 (0.001), significant at the 0.01 level. 
Because the earnings string firms in my sample have varying numbers of years of rising earnings, I also report results of trend regressions using firm-year observations in the last three years of the earnings string period. This sample represents all earnings string firms equally. Firmyear observations in the last year of the earnings string period are assigned the highest value and firm-year observations three years away from the earnings break are assigned the lowest value. Earnings string firm-year observations more than three years from the end of the earnings string period are not included. The advantage of this specification is that it controls for changes in the sample composition. The disadvantage of this method is that it truncates the firm-year observations of earnings string firms with more than three years of consecutive increasing earnings.

Panel B of Table 9 reports the trend regressions of earnings string firms in the last three years of their earnings string periods. The trend coefficient for discretionary accruals (performance-adjusted discretionary accruals) is $0.011(0.009)$, both significant at the 0.01 level. The results suggest that earnings string firms' discretionary accruals (performance-adjusted discretionary accruals) increase by $1.1(0.9)$ percent on average, each year in the three years leading to the end of the earnings string periods.

The industry adjusted WCNOA ratio trends upwards as earnings string firms near the end of their earnings string periods. The trend coefficient for the industry adjusted WCNOA ratio is 0.003 (t-statistic: $2.94, \mathrm{p}<0001$ ). The trend coefficient for WCNOA ratio is not significant at the 0.10 level (t-statistic: 1.08). The results provide mixed evidence to suggest that managers of 
earnings string firms are increasingly constrained by the available flexibility in their working capital to manage earnings upwards as they near the end of their earnings string periods

The NOA (industry adjusted NOA) ratio trends downwards in the last three years of the earnings string period. The trend coefficient for the NOA (industry adjusted NOA) ratio is -0.019 (-0.017), significant at the 0.01 level. The results are inconsistent with the increasing trend in income-increasing earnings management for these firms and consistent with the results of the time series analysis discussed earlier in Table 4. As previously discussed, it is not clear how the NOA ratio might be affected by firms' operational decisions.

To further analyze the relation between earnings management and accounting flexibility, I examine a subsample of earnings string firms that is more likely to have reduced levels of accounting flexibility at the end of their earnings string periods. Specifically, I retain earnings string firms that have engaged in income-increasing earnings management at least half of the years of their earnings string period (e.g., a firm that reports eight consecutive years of annual earnings increases would report four or more years of positive discretionary accruals). Based on this criterion, I obtain 5,513 earnings strings firms in this subsample (from the full earnings string sample of 10,562 earnings strings).

I rerun the trend regression tests using this subsample. Consistent with the notion that this subsample of earnings string firms would have engaged in more income-increasing earnings management, I obtain similar or stronger results across all measures. In the last three years of the earnings string period, the trend coefficient for the WCNOA ratio (industry adjusted WCNOA) 
ratio is $0.008(0.010)$, more than three times larger than the trend coefficient for the full earnings string sample. The coefficients are significant at the 0.01 level. The NOA and industry adjusted NOA ratios remain negative, but they are no longer significant at the 0.10 level. The trend coefficients for the NOA ratio and industry adjusted NOA ratio are -0.016 (t-statistic: -1.46 ) and -0.012 (t-statistic: -1.20$)$ respectively.

Overall, I interpret the results of the trend regression tests to suggest that managers of earnings string firms increasingly resort to income-increasing earnings management as they near the end of their earnings string periods, as evidenced by the positive trend coefficients for all three earnings management measures (discretionary accruals, performance adjusted discretionary accruals, performance matched discretionary accruals) across both specifications of the trend regression tests. As income-increasing earnings management variables trend higher toward the break in the earnings string patterns, the results in the trend regression tests show evidence that earnings string firms report lower levels of accounting flexibility over the earnings string period (Panel A, Table 9). I find mixed evidence in the trend regression results for the accounting flexibility measures when I limit my analysis to the last three years of the earnings string period (Panel B, Table 9). Specifically, the WCNOA ratio appears to be a better measure than the NOA ratio in capturing the reduced accounting flexibility associated with higher income-increasing earnings management, and the industry adjusted WCNOA ratio appears to perform better than its unadjusted counterpart. 
Table 9: Trend Analysis - Accounting Flexibility and Earnings Management

\begin{tabular}{|c|c|c|c|c|c|}
\hline & \multirow[b]{2}{*}{ Pred. sign } & \multicolumn{2}{|l|}{ TREND } & \multicolumn{2}{|l|}{ TREND } \\
\hline & & Coef. Est & t-statistics & Coef. Est & t-statistics \\
\hline & & \multicolumn{2}{|c|}{$\underline{\text { Full sample }}$} & \multicolumn{2}{|c|}{$\underline{\text { High EM sample }}$} \\
\hline \multicolumn{6}{|l|}{ Dependent variable } \\
\hline Discretionary accruals & + & 0.001 & $10.88^{* * *}$ & 0.003 & $16.58^{* * *}$ \\
\hline Performance adjusted DA & + & 0.001 & $11.22^{* * *}$ & 0.003 & $16.71^{* * *}$ \\
\hline Performance matched DA & + & 0.001 & $7.62^{* * *}$ & 0.003 & $10.84^{* * *}$ \\
\hline NOA ratio & + & 0.015 & $14.01^{* * *}$ & 0.015 & $10.81^{* * *}$ \\
\hline Industry adjusted NOA ratio & + & 0.009 & $9.76^{* * *}$ & 0.008 & $6.90^{* * *}$ \\
\hline WCNOA ratio & + & 0.001 & $2.94^{* * *}$ & 0.001 & $3.42^{* * *}$ \\
\hline Industry adjusted WCNOA ratio & + & 0.001 & $7.41^{* * *}$ & 0.002 & $7.08^{* * *}$ \\
\hline \multicolumn{6}{|c|}{ Panel B: Last three years of earnings string period years } \\
\hline & & TREND & & TREND & \\
\hline & Pred. sign & Coef. Est & t-statistics & Coef. Est & t-statistics \\
\hline & & \multicolumn{2}{|c|}{$\underline{\text { Full sample }}$} & \multicolumn{2}{|c|}{$\underline{\text { High EM sample }}$} \\
\hline \multicolumn{6}{|l|}{ Dependent variable } \\
\hline$\overline{\text { Discretionary accruals }}$ & + & 0.011 & $14.58^{* * *}$ & 0.011 & $10.26^{* * *}$ \\
\hline Performance adjusted DA & + & 0.009 & $13.00^{* * *}$ & 0.010 & $10.39^{* * *}$ \\
\hline Performance matched DA & + & 0.008 & $7.41^{* * *}$ & 0.007 & $4.41^{* * *}$ \\
\hline NOA ratio & + & -0.019 & $-2.31^{* *}$ & -0.016 & -1.46 \\
\hline Industry adjusted NOA ratio & + & -0.017 & $-2.17^{* *}$ & -0.012 & -1.20 \\
\hline WCNOA ratio & + & 0.001 & 1.08 & 0.008 & $4.88^{* * *}$ \\
\hline Industry adjusted WCNOA ratio & + & 0.003 & $2.94^{* * *}$ & 0.010 & $7.13^{* * *}$ \\
\hline
\end{tabular}

\section{Notes to Table 9}

Table 9 reports the results of trend regressions for the various earnings management variables for the full earnings string sample and for the high EM subsample between 1952-2005. High earnings management (EM) earnings string firms are defined as earnings string firms that engage in incomeincreasing earnings management (measured using discretionary accruals) in at least half the years during their earnings string period. TREND is measured in event-time and is defined as the proximity of the firm-year observation to the end of the earnings string period. Earnings string firm-year observations in the last year of the earnings string period are assigned the highest value and firm-year observations furthest from the break in the earnings string are assigned the lowest value. ${ }^{* * *} / * * / *$ denotes significance levels at the $1 \%, 5 \%$ and $10 \%$ level (two-tailed) respectively. See appendix for variable definitions. 


\subsubsection{Logistic regression - Main results}

To test the hypothesis that managers are constrained from engaging in income-increasing earnings management when the earnings string pattern ends, I run a logistic regression that models the likelihood of breaking an earnings string pattern as a function of firms' operating assets (equation 2). I use both NOA and WCNOA ratios as well as their industry-adjusted measures as my earnings management constraint variable in the logistic regression tests.

Table 10 reports the results of the logistic regression tests. Inconsistent with my prediction in hypothesis 2, I find a negative association between the likelihood of a firm breaking its earnings string pattern and higher NOA ratios across all earnings string samples. Similarly, I also find a negative association between the likelihood of the break in the earnings string and higher levels of WCNOA ratios for the second and third earnings string samples.

I find a positive association between the likelihood of the break in the earnings string and higher levels of WCNOA (industry adjusted WCNOA) ratios for the first earnings string sample, significant at the 0.05 (0.01) level. The results suggest that earnings string firms, on average, do not fully expend their accounting flexibility prior to a break in the earnings string period, except that firms in the first earnings string sample may have expended the accounting flexibility in their working capital net operating assets. This set of results is consistent with the earnings management test results for the first earnings string sample which show that these firms have higher levels of discretionary accruals compared to the second (or third) earnings string samples. 
Table 10: Logistic Regression of Earnings Breaks - Main Results

\begin{tabular}{|c|c|c|c|c|c|}
\hline Variables & Pred. sign & Coef. Est & z-statistics & Coef. Est & z-statistics \\
\hline & & $\underline{\text { Model } 1}$ & & $\underline{\text { Model } 2}$ & \\
\hline NOA ratio & + & -0.025 & $-2.28^{* *}$ & -0.018 & -1.51 \\
\hline SIZE & + & 0.069 & $8.60^{* * *}$ & 0.068 & $8.56^{* * *}$ \\
\hline LEVERAGE & + & 0.545 & $6.84^{* * *}$ & 0.533 & $6.70^{* * *}$ \\
\hline GROWTH & - & -0.504 & $9.20^{* * *}$ & -0.501 & $-9.17^{* * *}$ \\
\hline FIRM AGE & + & 0.647 & $20.71^{* * *}$ & 0.649 & $20.73^{* * *}$ \\
\hline Number of observations & & 27,686 & & 27,686 & \\
\hline Pseudo R ${ }^{2}$ & & 0.032 & & 0.032 & \\
\hline WCNOA ratio & + & 0.150 & $2.01^{* *}$ & 0.294 & $3.36^{* * *}$ \\
\hline SIZE & + & 0.072 & $8.59^{* * *}$ & 0.071 & $8.71^{* * *}$ \\
\hline LEVERAGE & + & 0.528 & $6.51^{* * *}$ & 0.504 & $6.20^{* * *}$ \\
\hline GROWTH & - & -0.505 & $-9.20^{* * *}$ & -0.507 & $-9.24^{* * *}$ \\
\hline FIRM AGE & + & 0.648 & $20.44^{* * *}$ & 0.648 & $20.45^{* * *}$ \\
\hline Number of observations & & 27,444 & & 27,444 & \\
\hline Pseudo R² & & 0.032 & & 0.032 & \\
\hline \multicolumn{6}{|c|}{ Panel B: Second earnings string sample } \\
\hline \multirow[t]{2}{*}{ Variables } & Pred. sign & Coef. Est & z-statistics & Coef. Est & z-statistics \\
\hline & & $\underline{\text { Model } 1}$ & & Model 2 & \\
\hline NOA ratio & + & -0.045 & -1.42 & -0.041 & -1.08 \\
\hline SIZE & + & 0.006 & 0.58 & 0.005 & 0.50 \\
\hline LEVERAGE & + & 0.771 & $6.96^{* * *}$ & 0.758 & $6.85^{* * *}$ \\
\hline GROWTH & - & 0.056 & 0.45 & 0.055 & 0.44 \\
\hline FIRM AGE & + & 0.836 & $19.27^{* * *}$ & 0.838 & $19.29^{* * *}$ \\
\hline Number of observations & & 13,229 & & 13,229 & \\
\hline Pseudo R ${ }^{2}$ & & 0.018 & & 0.018 & \\
\hline WCNOA ratio & + & -0.269 & $-2.44^{* *}$ & -0.162 & -1.17 \\
\hline SIZE & + & -0.002 & 0.16 & 0.002 & 0.24 \\
\hline LEVERAGE & + & 0.777 & $7.06^{* * *}$ & 0.772 & $6.86^{* * *}$ \\
\hline GROWTH & - & 0.053 & 0.43 & 0.058 & 0.47 \\
\hline FIRM AGE & + & 0.842 & $19.20^{* * *}$ & 0.839 & $19.19^{* * *}$ \\
\hline Number of observations & & 13,141 & & 13,141 & \\
\hline Pseudo R² & & 0.018 & & 0.018 & \\
\hline
\end{tabular}




\section{Table 10 (Continued)}

Panel C: Third earnings string sample

\begin{tabular}{|c|c|c|c|c|c|}
\hline Variables & Pred. sign & Coef. Est & z-statistics & Coef. Est & z-statistics \\
\hline & & $\underline{\text { Model } 1}$ & & Model 2 & \\
\hline NOA ratio & + & -0.212 & $-4.12^{* * *}$ & -0.200 & $-3.68^{* * *}$ \\
\hline SIZE & + & 0.002 & 0.16 & -0.003 & 0.28 \\
\hline LEVERAGE & + & 1.025 & $5.77^{* * *}$ & 0.988 & $5.65^{* * *}$ \\
\hline GROWTH & - & 0.299 & 1.48 & 0.284 & 1.42 \\
\hline FIRM AGE & + & 1.086 & $15.21^{* * *}$ & 1.083 & $15.16^{* * *}$ \\
\hline Number of observations & & 6,068 & & 6,068 & \\
\hline Pseudo R ${ }^{2}$ & & 0.019 & & 0.019 & \\
\hline WCNOA ratio & + & -0.481 & $-2.78^{* * *}$ & -0.502 & $-2.23^{* *}$ \\
\hline SIZE & + & -0.014 & -1.13 & -0.010 & -0.82 \\
\hline LEVERAGE & + & 0.934 & $5.45^{* * *}$ & 0.974 & $5.53^{* * *}$ \\
\hline GROWTH & - & 0.284 & 1.41 & 0.302 & 1.50 \\
\hline FIRM AGE & + & 1.092 & $15.36^{* * *}$ & 1.097 & $15.46^{* * *}$ \\
\hline Number of observations & & 5,995 & & 5,995 & \\
\hline Pseudo $\mathrm{R}^{2}$ & & 0.036 & & 0.041 & \\
\hline
\end{tabular}

\section{Notes to Table 10}

Table 10 reports the results of the logit regressions of the earnings management constraint tests. The first/second/third string sample comprises 6,130/2,540/1,132 earnings string firms as described in Table 1 . The dependent variable in the regressions is a binary variable denoting 1 if the firm-year observation breaks its earnings string pattern and 0 otherwise. An earnings string firm breaks its earnings string pattern when it stops reporting an annual EPS increase after three or more years of consecutive annual EPS increases. The variable of interest is the accounting flexibility measure, measured using NOA ratio and WCNOA ratio. Model 1 uses unadjusted accounting flexibility measures. Model 2 uses industry adjusted accounting flexibility measures. z-statistics are heteroscedasticity-consistent and adjusted for residual correlation among observations pertaining to the same firm. ${ }^{* *} / * * *$ denotes significance levels at the $1 \%, 5 \%$ and $10 \%$ level (two-tailed) respectively. See appendix for variable definitions. 


\subsubsection{Logistic regression - High EM firms}

In this section, I probe the results in Table 10 by examining a subsample that is more likely to have exhausted accounting flexibility. As with the trend regression tests, I use the subsample of firms with income-increasing discretionary accruals in at least half the years of their earnings string periods as defined earlier. I focus on this subsample because their relatively consistent use of income-increasing earnings management should increase the likelihood of exhausting their accounting flexibility

Table 11 reports the results of this analysis. I find that a high WCNOA ratio is positively associated with the likelihood of firms breaking their earnings string. Specifically, the coefficients on the WCNOA ratio are positive and significant at the 0.01 level for the first earnings string sample and at the 0.10 level for the second earnings string sample. The association is positive but not significant at the 0.10 level (t-statistic: 1.42) for the third earnings string sample. Results are stronger based on industry-adjusted WCNOA ratios. The first and second earnings string samples report a positive association $(\mathrm{p}<0.001)$ between higher industry adjusted WCNOA ratios and the likelihood of breaking an earnings string, and the third earnings string sample reports a positive association, significant at the 0.10 level. The results suggest that these firms use up the accounting flexibility in their working capital at the end of their earnings string periods. This is consistent with the earnings management literature that suggests working capital accruals are more likely to be managed than long term accruals. 
My results also suggest that even firms that repeatedly engage in income-increasing earnings management do not exhaust the accounting flexibility in their long-term assets. I find either no association or a negative association between the NOA ratio and the likelihood of breaking an earnings string for these firms. I interpret my results as suggesting either that these firms do not use all available accounting flexibility, even when faced with the prospect of reporting an earnings decrease, or that income-increasing earnings management is not readily available for long term net operating assets. 
Table 11: Logistic Regression of Earnings Breaks - High EM Earnings String Firms

\begin{tabular}{|c|c|c|c|c|c|}
\hline Variables & Pred. sign & Coef. Est & z-statistics & Coef. Est & z-statistics \\
\hline & & $\underline{\text { Model } 1}$ & & $\underline{\text { Model } 2}$ & \\
\hline NOA ratio & + & -0.024 & -1.64 & -0.013 & -0.84 \\
\hline SIZE & + & 0.084 & $7.03^{* * *}$ & 0.083 & $7.00^{* * *}$ \\
\hline LEVERAGE & + & 0.747 & $6.75^{* * *}$ & 0.735 & $6.65^{* * *}$ \\
\hline GROWTH & - & -0.842 & $-10.40^{* * *}$ & -0.836 & $-10.36^{* * *}$ \\
\hline FIRM AGE & + & 0.560 & $13.49^{* * *}$ & 0.562 & $13.52^{* * *}$ \\
\hline Number of observations & & 15,085 & & 15,085 & \\
\hline Pseudo R 2 & & 0.037 & & 0.037 & \\
\hline WCNOA ratio & + & 0.778 & $6.59^{* * *}$ & 1.124 & $7.83^{* * *}$ \\
\hline SIZE & + & 0.100 & $7.84^{* * *}$ & 0.091 & $7.33^{* * *}$ \\
\hline LEVERAGE & + & 0.716 & $6.37^{* * *}$ & 0.653 & $5.83^{* * *}$ \\
\hline GROWTH & - & -0.885 & $-10.72^{* * *}$ & -0.886 & $-10.78^{* * *}$ \\
\hline FIRM AGE & + & 0.542 & $12.59^{* * *}$ & 0.554 & $13.05^{* * *}$ \\
\hline Number of observations & & 14,934 & & 14,934 & \\
\hline Pseudo $R^{2}$ & & 0.040 & & 0.042 & \\
\hline \multicolumn{6}{|c|}{ Panel B: Second earnings string sample } \\
\hline \multirow[t]{2}{*}{ Variables } & Pred. sign & Coef. Est & z-statistics & Coef. Est & z-statistics \\
\hline & & $\underline{\text { Model } 1}$ & & $\underline{\text { Model } 2}$ & \\
\hline NOA ratio & + & -0.075 & $-1.73^{*}$ & -0.053 & -1.16 \\
\hline SIZE & + & 0.024 & $1.81^{*}$ & 0.021 & $1.65^{*}$ \\
\hline LEVERAGE & + & 1.062 & $6.85^{* * *}$ & 1.036 & $6.70^{* * *}$ \\
\hline GROWTH & - & -0.094 & -0.52 & -0.093 & -0.52 \\
\hline FIRM AGE & + & 1.017 & $17.81^{* * *}$ & 1.022 & $17.91^{* * *}$ \\
\hline Number of observations & & 6,889 & & 6,889 & \\
\hline Pseudo R ${ }^{2}$ & & 0.028 & & 0.027 & \\
\hline WCNOA ratio & + & 0.255 & $1.64^{*}$ & 0.423 & $2.04^{* * *}$ \\
\hline SIZE & + & 0.027 & $1.96^{* *}$ & 0.024 & $1.84^{* *}$ \\
\hline LEVERAGE & + & 0.973 & $6.32^{* * *}$ & 0.942 & $6.05^{* * *}$ \\
\hline GROWTH & - & -0.090 & -0.50 & -0.094 & -0.52 \\
\hline FIRM AGE & + & 1.013 & $17.63^{* * *}$ & 1.014 & $17.68^{* * *}$ \\
\hline Number of observations & & 6,831 & & 6,831 & \\
\hline Pseudo R² & & 0.027 & & 0.027 & \\
\hline
\end{tabular}




\section{Table 11 (Continued)}

Panel C: Third earnings string sample

\begin{tabular}{|c|c|c|c|c|c|}
\hline Variables & Pred. sign & Coef. Est & z-statistics & Coef. Est & z-statistics \\
\hline & & $\underline{\text { Model } 1}$ & & $\underline{\text { Model } 2}$ & \\
\hline NOA ratio & + & -0.122 & $-1.77^{*}$ & -0.076 & -1.09 \\
\hline SIZE & + & -0.003 & -0.15 & -0.007 & -0.40 \\
\hline LEVERAGE & + & 1.072 & $4.44^{* * *}$ & 1.027 & $4.31^{* * *}$ \\
\hline GROWTH & - & 0.009 & 0.03 & -0.010 & 0.04 \\
\hline FIRM AGE & + & 1.269 & $12.45^{* * *}$ & 1.274 & $12.45^{* * *}$ \\
\hline Number of observations & & 3,128 & & 3,128 & \\
\hline Pseudo $\mathrm{R}^{2}$ & & 0.019 & & 0.019 & \\
\hline WCNOA ratio & + & 0.339 & 1.42 & 0.574 & $1.79^{*}$ \\
\hline SIZE & + & -0.002 & -0.08 & -0.004 & -0.20 \\
\hline LEVERAGE & + & 0.982 & $4.17^{* * *}$ & 0.914 & $3.77^{* * *}$ \\
\hline GROWTH & - & 0.015 & 0.06 & -0.003 & -0.01 \\
\hline FIRM AGE & + & 1.295 & $12.24^{* * *}$ & 1.298 & $12.20^{* * *}$ \\
\hline Number of observations & & 3,077 & & 3,077 & \\
\hline Pseudo R ${ }^{2}$ & & 0.023 & & 0.023 & \\
\hline
\end{tabular}

\section{Notes to Table 11}

Table 11 reports the results of the logit regressions of the earnings management constraint tests based on earnings string firms with income-increasing discretionary accruals in at least half of the years of their earnings string period (high EM firms). There are 3,216/1,333/584 high EM firms in the first/second/third string sample. The dependent variable in the regressions is a binary variable denoting 1 if the firm-year observation breaks its earnings string pattern and 0 otherwise. An earnings string firm breaks its earnings string pattern when it stops reporting an annual EPS increase after three or more years of consecutive annual EPS increases. The variable of interest is the accounting flexibility measure, measured using NOA ratio and WCNOA ratio. Model 1 uses unadjusted accounting flexibility measures. Model 2 uses industry adjusted accounting flexibility measures. z-statistics are heteroscedasticity-consistent and adjusted for residual correlation among observations pertaining to the same firm. ${ }^{* * * * * / *}$ denotes significance levels at the $1 \%, 5 \%$ and $10 \%$ level (two-tailed) respectively. See appendix for variable definitions. 


\subsubsection{Logistic regression - pre-managed earnings shortfall}

In this section, I investigate whether earnings string firms that have pre-managed EPS declines in the last year of their earnings strings have reduced accounting flexibility when their earnings strings break. To continue an earnings string when pre-managed earnings would decrease, managers have to rely on more income-increasing earnings management to bridge the earnings gap between their pre-managed EPS and their desired reported EPS. I conjecture that managers for these earnings string firms use up more of their available accounting flexibility to ensure that their firms are able to report an EPS increase in the last year of the earnings string period. Hence, these firms do not have sufficient accounting flexibility to manage earnings upwards in the next year.

I partition my sample into earnings string firms whose pre-managed EPS in year $t-1$ is lower (higher) than their pre-managed EPS in year $t$-2. I measure pre-managed EPS for each firm in each year by subtracting the firm's discretionary accruals per share from its reported earnings per share. There are 4,250 earnings string firms whose pre-managed EPS in year $t-1$ is lower than their pre-managed EPS in year $t$-2, suggesting that the managers of these firms have to engage in a higher level of income-increasing earnings management to report an EPS increase. Consistent with the notion that these managers will have to use up more of the available accounting flexibility, I find that the likelihood of breaking the earnings string is positively associated with

reduced accounting flexibility in my logistic regression tests based on the WCNOA ratio, but not the NOA ratio. Results of this test are reported in Table 12. Specifically, the coefficients on the 
WCNOA ratio and the likelihood of a firm breaking its earnings string are positive and significant at the 0.01 level for both the first and second earnings string samples and at the 0.10 level for the third second earnings string sample. The results suggest that these firms use up the accounting flexibility in their working capital at the end of their earnings string periods. On the other hand, as with my earlier earnings management constraint tests, I do not obtain positive results using tests based on the NOA ratios.

Overall, the results in the earnings management constraint tests suggest that while the average earnings string firm apparently does not run out of accounting flexibility when its earnings string pattern breaks, earnings string firms that have engaged in income-increasing earnings management, either throughout the earnings string period or in the last year of the earnings string period, run out of accounting flexibility in their working capital net operating assets in the year of the earnings string break. 
Table 12: Logistic Regression of Earnings Breaks - Pre-managed Earnings Shortfalls

\begin{tabular}{|c|c|c|c|c|c|}
\hline Variables & Pred. sign & Coef. Est & z-statistics & Coef. Est & z-statistics \\
\hline & & $\underline{\text { Model } 1}$ & & $\underline{\text { Model } 2}$ & \\
\hline NOA ratio & + & 0.002 & 0.12 & 0.013 & 0.65 \\
\hline SIZE & + & 0.064 & $5.16^{* * *}$ & 0.064 & $5.17^{* * *}$ \\
\hline LEVERAGE & + & 0.805 & $6.13^{* * *}$ & 0.800 & $6.08^{* * *}$ \\
\hline GROWTH & - & -0.653 & $-7.34^{* * *}$ & -0.651 & $-7.32^{* * *}$ \\
\hline FIRM AGE & + & 0.627 & $13.91^{* * *}$ & 0.628 & $13.88^{* * *}$ \\
\hline Number of observations & & 11,831 & & 11,831 & \\
\hline Pseudo R ${ }^{2}$ & & 0.034 & & 0.035 & \\
\hline WCNOA ratio & + & 0.814 & $5.86^{* * *}$ & 1.098 & $3.36^{* * *}$ \\
\hline SIZE & + & 0.084 & $6.38^{* * *}$ & 0.075 & $8.71^{* * *}$ \\
\hline LEVERAGE & + & 0.749 & $5.63^{* * *}$ & 0.669 & $6.20^{* * *}$ \\
\hline GROWTH & - & -0.694 & $-7.64^{* * *}$ & -0.691 & $-9.24^{* * *}$ \\
\hline FIRM AGE & + & 0.604 & $13.07^{* * *}$ & 0.615 & $20.45^{* * *}$ \\
\hline Number of observations & & 11,723 & & 11,723 & \\
\hline Pseudo R ${ }^{2}$ & & 0.038 & & 0.040 & \\
\hline \multicolumn{6}{|c|}{ Panel B: Second earnings string sample } \\
\hline \multirow[t]{2}{*}{ Variables } & Pred. sign & Coef. Est & z-statistics & Coef. Est & z-statistics \\
\hline & & $\underline{\text { Model } 1}$ & & Model 2 & \\
\hline NOA ratio & + & 0.021 & 0.39 & 0.035 & 0.53 \\
\hline SIZE & + & -0.003 & -0.18 & -0.002 & -0.16 \\
\hline LEVERAGE & + & 1.049 & $5.68^{* * *}$ & 1.048 & $5.72^{* * *}$ \\
\hline GROWTH & - & -0.286 & -1.48 & -0.286 & -1.49 \\
\hline FIRM AGE & + & 0.941 & $15.37^{* * *}$ & 0.940 & $15.28^{* * *}$ \\
\hline Number of observations & & 5,942 & & 5,942 & \\
\hline Pseudo R ${ }^{2}$ & & 0.023 & & 0.023 & \\
\hline WCNOA ratio & + & 0.500 & $2.94^{* * *}$ & 0.779 & $3.93^{* * *}$ \\
\hline SIZE & + & 0.012 & 0.82 & 0.010 & 0.65 \\
\hline LEVERAGE & + & 1.061 & $5.85^{* * *}$ & 1.000 & $5.45^{* * *}$ \\
\hline GROWTH & - & -0.267 & -1.37 & -0.258 & -1.32 \\
\hline FIRM AGE & + & 0.940 & $15.12^{* * *}$ & 0.946 & $15.14^{* * *}$ \\
\hline Number of observations & & 5,887 & & 5,887 & \\
\hline Pseudo R ${ }^{2}$ & & 0.024 & & 0.025 & \\
\hline
\end{tabular}




\section{Table 12 (Continued)}

Panel C: Third earnings string sample

\begin{tabular}{|c|c|c|c|c|c|}
\hline Variables & Pred. sign & Coef. Est & z-statistics & Coef. Est & z-statistics \\
\hline & & $\underline{\text { Model } 1}$ & & $\underline{\text { Model } 2}$ & \\
\hline NOA ratio & + & -0.124 & -1.58 & -0.046 & -0.60 \\
\hline SIZE & + & 0.010 & 0.52 & 0.007 & 0.37 \\
\hline LEVERAGE & + & 1.180 & $4.31^{* * *}$ & 1.116 & $4.07^{* * *}$ \\
\hline GROWTH & - & -0.105 & -0.34 & -0.103 & -0.34 \\
\hline FIRM AGE & + & 1.085 & $10.37^{* * *}$ & 1.093 & $10.32^{* * *}$ \\
\hline Number of observations & & 2,776 & & 2,776 & \\
\hline Pseudo R² & & 0.019 & & 0.019 & \\
\hline WCNOA ratio & + & 0.416 & $1.73^{*}$ & 0.464 & 1.56 \\
\hline SIZE & + & 0.016 & 0.76 & 0.013 & 0.61 \\
\hline LEVERAGE & + & 1.089 & $4.17^{* * *}$ & 1.048 & $3.88^{* * *}$ \\
\hline GROWTH & - & -0.018 & -0.06 & -0.031 & -0.10 \\
\hline FIRM AGE & + & 1.085 & $10.08^{* * *}$ & 1.080 & $10.05^{* * *}$ \\
\hline Number of observations & & 2,748 & & 2,748 & \\
\hline Pseudo R² & & 0.019 & & 0.019 & \\
\hline
\end{tabular}

\section{Notes to Table 12}

Table 12 reports the results of the logit regressions of the earnings management constraint tests. The first/second/third earnings string sample comprises 2,599/1,130/521 earnings string firms whose premanaged earnings in the last year of the earnings string period is lower than prior year's pre-managed earnings. The dependent variable in the regressions is a binary variable denoting 1 if the firm-year observation breaks its earnings string pattern and 0 otherwise. An earnings string firm breaks its earnings string pattern when it stops reporting an annual EPS increase after three or more years of consecutive annual EPS increases. The variable of interest is the accounting flexibility measure, measured using NOA ratio and WCNOA ratio. Model 1 uses unadjusted accounting flexibility measures. Model 2 uses industry adjusted accounting flexibility measures. $z$-statistics are heteroscedasticity-consistent and adjusted for residual correlation among observations pertaining to the same firm. ${ }^{* * * * *} / *$ denotes significance levels at the $1 \%, 5 \%$ and $10 \%$ level (two-tailed) respectively. See appendix for variable definitions. 


\subsection{Valuation tests}

\subsubsection{Main results}

In this section, I examine how the market reacts to firms that consistently report earnings increases, and whether the market is able to see through income-increasing earnings management activities that managers undertake to extend the earnings string patterns. This analysis provides insights as to why managers apparently seek to extend the earnings string patterns of their firms and also provides support for my earnings management hypotheses.

I first examine whether a valuation premium accrues to firms during an earnings string period, and whether the valuation premium is reduced when the earnings strings end. The purpose of these tests is to show that managers have incentives to engage in income-increasing earnings management to extend their firms' earnings string patterns.

I use price regressions to control for differences in firm characteristics so as to assess whether there is a valuation premium for earnings string firms (for reporting consecutively increasing earnings) compared to the Compustat population. I use the price regressions' specifications in Barth et al. (1999) for my valuation tests. I estimate the price regressions based on all Compustat firms between 1952-2006 excluding banks and utilities. Specifically, I estimate the following regression:

$$
\begin{aligned}
& \text { PRICE }_{i, t}=\alpha_{0}+\alpha_{1} \text { EPS }_{i, t}+\alpha_{2}\left(\operatorname{STRING}_{i, t} \times \mathrm{EPS}_{i, t}\right)+\alpha_{3}\left(\mathrm{EVAR}_{i, t} \times \mathrm{EPS}_{i, t}\right)+ \\
& \alpha_{4}\left(\mathrm{GROWTH}_{i, t} \times \mathrm{EPS}_{i, t}\right)+\alpha_{5}\left(\mathrm{LEVERAGE}_{i, t} \times \mathrm{EPS}_{i, t}\right)+\alpha_{6}\left(\mathrm{BVE}_{i, t} \times \mathrm{EPS}_{i, t}\right)+\varepsilon_{i, t}
\end{aligned}
$$


where PRICE is the fiscal year-end stock price of firm $i$ in year $t$, STRING is an indicator variable $=1$ for firm-year observations in which the firm reports at least three consecutive years of annual EPS increases and 0 otherwise, EPS is the firm's earnings per share before extraordinary items (Compustat \#58), EVAR is the variance of the past four years' percentage change in earnings per share, GROWTH is the three-year compounded annual growth rate of book value of firm's $i$ equity (Compustat \#60), LEVERAGE is the firm's debt-to-equity ratio (Compustat \#34+\#9/Compustat \#60) and BVE is the firm's book value of equity per share (Compustat \#60/\#25). ${ }^{5}$

Similar to Barth et al., I use a pooled regression (controlling for year effects) and FamaMacBeth separate-year regressions. As with Barth et al., I estimate equation (3) with and without BVE. Including the book value of equity as an additional control variable should improve the price regression specification. I expect $\alpha_{2}>0$, indicating that firms with at least three years of increasing earnings have a higher stock price than peer firms with comparable growth, leverage and risk characteristics (or equivalently a higher earnings multiple than other comparable firms).

Table 13 reports the results of the price regressions. My results vary depending on specifications but they consistently show a positive coefficient for $\alpha_{2}$, indicating that there is a valuation premium for earnings string firms. For example, I find a positive coefficient of 2.125 ( $t$ statistic: 39.25, $\mathrm{p}<0.001)$ for $\alpha_{2}$ in the pooled regression test (Panel A, Table 13), implying that

${ }^{5}$ Barth et al. (1999) examine earnings string firms with five or more consecutive years of increasing earnings. Hence, they measure growth and volatility based on a five-year horizon. My tests are based on earnings string firms with three or more consecutive years of increasing earnings. Therefore, I measure growth and volatility based on a three-year horizon. 
earnings string firms trade at higher price-multiples relative to other Compustat firms that do not report an earnings string. That is, an earnings string firm is priced higher than a comparable nonearnings string firm with the same level of earnings per share by $\$ 2.13$. Compared with Barth et al.'s results, I find a smaller valuation premium, perhaps because their sample is composed of earnings string firms with at least five years of consecutive annual earnings increase. They find that their earnings string sample firms' stock price is priced higher by $\$ 3.16$ compared to their peer firms.

I also examine whether firms that break their earnings strings still retain the valuation premium. If they do not, this will provide an economic impetus for managers of earnings string firms to delay the reporting of an earnings break so as to preserve firm valuations. To measure the stock price effect of the break in an earnings string pattern, I estimate the following regression based on all Compustat firms between 1952-2006 excluding banks and utilities:

$$
\begin{aligned}
& \operatorname{PRICE}_{i, t}=\alpha_{0}+\alpha_{1} \mathrm{EPS}_{i, t}+\alpha_{2}\left(\mathrm{BREAK}_{i, t} \times \mathrm{EPS}_{i, t}\right)+\alpha_{3}\left(\mathrm{EVAR}_{i, t} \times \mathrm{EPS}_{i, t}\right)+ \\
& \alpha_{4}\left(\mathrm{GROWTH}_{i, t} \times \mathrm{EPS}_{i, t}\right)+\alpha_{5}\left(\mathrm{LEVERAGE}_{i, t} \times \mathrm{EPS}_{i, t}\right)+\alpha_{6}\left(\mathrm{BVE}_{i, t} \times \mathrm{EPS}_{i, t}\right)+\varepsilon_{i, t}
\end{aligned}
$$

where BREAK is an indicator variable $=1$ for firm-year observations in which an earnings string firm fails to report an annual EPS increase after three or more consecutive years of annual EPS increases and 0 otherwise. All other variables are as defined in equation (3). Results in Table 13 Panel B show that firms which break their earnings string are priced no different or lower $\left(\alpha_{2}\right.$ $\leq 0$ ) than all other Compustat firms. The coefficients for $\alpha_{2}$ range from -0.520 (t-statistic: -5.70 , $\mathrm{p}<0.001)$ to 0.009 (t-statistic: 0.09). 
Table 13: Price Regressions

Panel A: String Sample

\begin{tabular}{|c|c|c|c|c|c|}
\hline Variables & Pred sign & Coef. Est & t-statistics & Coef. Est & t-statistics \\
\hline \multicolumn{6}{|c|}{ Pooled sample regression } \\
\hline EPS & + & 10.055 & $23.39 * * *$ & 7.322 & $13.21^{* * *}$ \\
\hline STRING $x$ EPS & + & 1.731 & $31.73^{* * *}$ & 2.125 & $39.25^{* * *}$ \\
\hline EVAR x EPS & - & -0.601 & $-23.29^{* * *}$ & -0.730 & $-37.23^{* * *}$ \\
\hline GROWTH x EPS & + & 0.273 & $1.80^{*}$ & 0.937 & $7.01^{* * *}$ \\
\hline LEVERAGE $\times$ EPS & - & -0.660 & $-27.75^{* * *}$ & -0.345 & $-15.86^{* * *}$ \\
\hline BVE & + & & & 0.483 & $65.40^{* * *}$ \\
\hline Year effect & & Included & & Included & \\
\hline $\mathrm{n}$ & & 127,300 & & 127,180 & \\
\hline Adj $R^{2}$ & & 0.50 & & 0.58 & \\
\hline Variables & Pred sign & Coef. Est & t-statistics & Coef. Est & t-statistics \\
\hline \multicolumn{6}{|c|}{ Separate-year regressions } \\
\hline EPS & + & 6.992 & $14.89^{* * *}$ & 5.296 & $13.46^{* * *}$ \\
\hline STRING x EPS & + & 1.846 & $8.79 * * *$ & 1.930 & $10.74^{* * *}$ \\
\hline EVAR x EPS & - & -0.601 & $-5.57^{* * *}$ & -0.669 & $-9.08^{* * *}$ \\
\hline GROWTH x EPS & + & 1.883 & $4.10^{* * *}$ & 2.319 & $4.81^{* * *}$ \\
\hline LEVERAGE $x$ EPS & - & -0.616 & $-8.83^{* * *}$ & -0.380 & $-5.97^{* * *}$ \\
\hline BVE & + & & & 0.422 & $9.67^{* * *}$ \\
\hline Number of years & & 49 & & 49 & \\
\hline Mean Adj R² & & 0.41 & & 0.48 & \\
\hline
\end{tabular}




\section{Table 13 (Continued)}

Panel B: Break Sample

\begin{tabular}{|c|c|c|c|c|c|}
\hline Variables & Pred sign & Coef. Est & t-statistics & Coef. Est & $\mathrm{t}$-statistics \\
\hline \multicolumn{6}{|c|}{ Pooled sample regression } \\
\hline EPS & + & 10.939 & $24.53^{* * *}$ & 9.076 & $16.97^{* * *}$ \\
\hline BREAK $x$ EPS & - & 0.009 & 0.09 & -0.520 & $-5.70^{* * *}$ \\
\hline EVAR $x$ EPS & - & -0.647 & $-24.88^{* * *}$ & -0.786 & $-40.11^{* * *}$ \\
\hline GROWTH x EPS & + & 0.748 & $4.78^{* * *}$ & 1.517 & $10.79^{* * *}$ \\
\hline LEVERAGE $\times$ EPS & - & -0.695 & $-28.54^{* * *}$ & -0.396 & $-17.97^{* * *}$ \\
\hline BVE & + & & & 0.471 & $64.63^{* * *}$ \\
\hline Year effect & & Included & & Included & \\
\hline $\mathrm{n}$ & & 127,300 & & 127,180 & \\
\hline Adj $R^{2}$ & & 0.49 & & 0.57 & \\
\hline Variables & Pred sign & Coef. Est & t-statistics & Coef. Est & t-statistics \\
\hline \multicolumn{6}{|c|}{ Separate-year regressions } \\
\hline EPS & + & 7.764 & $15.70^{* * *}$ & 6.073 & $13.19^{* * *}$ \\
\hline BREAK $x$ EPS & - & -0.094 & -0.67 & -0.368 & $-2.78^{* * *}$ \\
\hline EVAR $x$ EPS & - & -0.705 & $-8.42^{* * *}$ & -0.723 & $-9.34^{* * *}$ \\
\hline GROWTH x EPS & + & 2.581 & $4.82^{* * *}$ & 3.094 & $5.57^{* * *}$ \\
\hline LEVERAGE $\times$ EPS & - & -0.662 & $-9.14^{* * *}$ & -0.441 & $-6.47^{* * *}$ \\
\hline BVE & + & & & 0.411 & $9.25^{* * *}$ \\
\hline Number of years & & 49 & & 49 & \\
\hline Mean Adj $\mathrm{R}^{2}$ & & 0.41 & & 0.48 & \\
\hline
\end{tabular}

\section{Notes to Table 13}

Table 13 reports the results of both pooled and Fama-MacBeth regressions for 16,764 Compustat firms with at least four years of reporting history between 1952-2006. t-statistics for the Fama-MacBeth regressions are calculated based on the standard errors of the coefficient estimates across years. The dependent variable is the firm's fiscal year-end share price. EPS denotes the firm's earnings per share before extraordinary items (Compustat \#58). GROWTH is calculated as the three-year compounded annual growth rate of book value of equity (Compustat \#60). EVAR is the variance of past 4 years' percentage change in earnings.

LEVERAGE is the firm's debt-to-equity ratio. The various indicator variables are defined as follows: BREAK: dummy variable $=1$ if the firm breaks its earnings string pattern (i.e. stop reporting an annual earnings increase after at least 3 consecutive years of earnings increases), and 0 otherwise. STRING:

dummy variable $=1$ if the firm has at least 3 consecutive years of increasing earnings, and 0 otherwise. $* * * * * / *$ denotes signficance levels at the $1 \%, 5 \%$ and $10 \%$ level (two-tailed) respectively. 


\subsubsection{Interaction with earnings management}

I next examine whether the stock market is able to see through the effects of earnings management and penalize earnings string firms whose managers engage in income-increasing earnings management during the earnings string period. If the market is unable to see through (or partially see through) earnings increases that are achieved by accruals management, there will be an incentive for managers to engage in income-increasing earnings management to maintain the earnings string. Prior research is mixed as to whether the market correctly prices discretionary accruals (Subramanyam 1996; Xie 2001). The restatement literature suggests that the market does not fully see through earnings management as evidenced by a decrease in firms' abnormal returns of about 9 percent over a 2-day announcement window when firms announce they are restating their financial statements (Palmrose, Richardson and Scholz 2004).

Table 14 reports the valuation tests for earnings string firms that have been engaging in income-increasing earnings management. I use three different specifications to assess whether the stock market penalizes managers for engaging in income-increasing earnings management. I include an earnings management (EM) variable in the price regressions and run the tests based on two separate definitions for the EM variable. In model 1, EM is the measure of the earnings string firm's modified Jones model discretionary accruals. In model 2, EM is an indicator variable $=1$ when the earnings string firm reports positive discretionary accruals, and 0 otherwise. I estimate this regression using all my earnings string firms: 


$$
\begin{aligned}
& \text { PRICE }_{i, t}=\alpha_{0}+\alpha_{1} \mathrm{EPS}_{i, t}+\alpha_{2}\left(\mathrm{EM}_{i, t} \times \mathrm{EPS}_{i, t}\right)+\alpha_{3}\left(\mathrm{EVAR}_{i, t} \times \mathrm{EPS}_{i, t}\right)+ \\
& \alpha_{4}\left(\mathrm{GROWTH}_{i, t} \times \mathrm{EPS}_{i, t}\right)+\alpha_{5}\left(\mathrm{LEVERAGE}_{i, t} \times \mathrm{EPS}_{i, t}\right)+\alpha_{6}\left(\mathrm{BVE}_{i, t} \times \mathrm{EPS}_{i, t}\right)+\varepsilon_{i, t}
\end{aligned}
$$

Panel A of Table 14 reports the results of these regressions. I expect $\alpha_{2}<0$, if the market is able to see through earnings increases that are achieved via accruals management. Consistent with this prediction, I find that the market penalizes earnings string firms whose managers engage in income-increasing earnings management. Specifically, my test results indicate that the market reduces the valuation premium between $\$ 1.11$ and $\$ 1.28$ for each percent of discretionary accruals of total assets based on the results from the first model specification. Results based on the second model specification show that when managers of earnings string firms engage in income-increasing earnings management, their firms, on average, receive a lower valuation premium of between $\$ 0.20$ to $\$ 0.23$ compared to earnings string firms that do not.

In my third specification, I test whether there is a differential valuation premium between high EM earnings string firms and low EM earnings string firms at the end of the earnings string period. Panel B of Table 14 reports the results of the price regressions when I partition the earnings string firms into high and low EM firms as defined earlier. Consistent with the results in Panel A, I find that high EM earnings string firms have a lower valuation premium (\$1.37 to \$1.83) compared to low EM earnings string firms (\$1.49 to \$1.96). However, the valuation difference is not reliably different at the 0.10 level (not tabulated). The results suggest that even if the market discerns and adjusts for income-increasing earnings management, 
managers still have an incentive to engage in income-increasing earnings management if doing so enables them to stay within the earnings string pattern. The results support prior research in the restatement literature that the market is not able to see through all of the effects of incomeincreasing earnings management and provide a rationale as to why managers of earnings string firms would want to engage in income-increasing earnings management to continue an earnings string. 
Table 14: Price Regressions - Impact of Income-increasing Earnings Management

Panel A: Effect of earnings management on earnings string sample

\begin{tabular}{|c|c|c|c|c|c|}
\hline Variables & Pred sign & Coef. Est & t-statistics & Coef. Est & t-statistics \\
\hline \multicolumn{6}{|l|}{ Model 1} \\
\hline EPS & + & 14.465 & $28.11^{* * *}$ & 14.082 & $26.88^{* * *}$ \\
\hline EM x EPS & - & -1.111 & $-2.09 * *$ & -1.284 & $-2.43^{* *}$ \\
\hline EVAR x EPS & - & -0.731 & $-16.65^{* * *}$ & -0.759 & $-18.40^{* * *}$ \\
\hline GROWTH x EPS & + & 1.913 & $7.56^{* * *}$ & 2.109 & $8.22^{* * *}$ \\
\hline LEVERAGE $x$ EPS & - & -0.578 & $-8.73^{* * *}$ & -0.552 & $-8.35^{* * *}$ \\
\hline BVE & + & & & 0.080 & $4.22^{* * *}$ \\
\hline Year effect & & Included & & Included & \\
\hline Number of observations & & 29,806 & & 29,792 & \\
\hline $\operatorname{Adj} R^{2}$ & & 0.58 & & 0.58 & \\
\hline Variables & Pred sign & Coef. Est & $\mathrm{t}$-statistics & Coef. Est & t-statistics \\
\hline \multicolumn{6}{|l|}{ Model 2} \\
\hline EPS & + & 14.570 & $28.17^{* * *}$ & 14.203 & $26.99^{* * *}$ \\
\hline EM $\times$ EPS & - & -0.202 & $-2.66^{* * *}$ & -0.226 & $-3.00^{* * *}$ \\
\hline EVAR $x$ EPS & - & -0.731 & $-16.72^{* * *}$ & -0.758 & $-18.46^{* * *}$ \\
\hline GROWTH x EPS & + & 1.900 & $7.59^{* * *}$ & 2.093 & $8.26^{* * *}$ \\
\hline LEVERAGE $x$ EPS & - & -0.580 & $-8.82^{* * *}$ & -0.556 & $-8.45^{* * *}$ \\
\hline BVE & + & & & 0.079 & $4.20^{* * *}$ \\
\hline Year effect & & Included & & Included & \\
\hline Number of observations & & 29,806 & & 29,792 & \\
\hline Adj $R^{2}$ & & 0.58 & & 0.58 & \\
\hline
\end{tabular}




\section{Table 14 (Continued)}

Panel B: Comparison of High EM and Low EM firms

\begin{tabular}{|c|c|c|c|c|c|}
\hline Variables & Pred sign & Coef. Est & t-statistics & Coef. Est & t-statistics \\
\hline \multicolumn{6}{|l|}{ High EM firms } \\
\hline EPS & + & 8.914 & $13.35^{* * *}$ & 5.077 & $8.32^{* * *}$ \\
\hline STRING $\times$ EPS & + & 1.368 & $17.30^{* * *}$ & 1.827 & $23.26^{* * *}$ \\
\hline EVAR x EPS & - & -0.590 & $-19.02^{* * *}$ & -0.696 & $-29.68^{* * *}$ \\
\hline GROWTH $x$ EPS & + & -0.341 & $-2.02^{* *}$ & 0.166 & 1.16 \\
\hline LEVERAGE $x$ EPS & - & -0.623 & $-24.31^{* * *}$ & -0.290 & $-12.55^{* * *}$ \\
\hline BVE & + & & & 0.543 & $58.20^{* * *}$ \\
\hline Year effect & & Included & & Included & \\
\hline Number of observations & & 95,515 & & 95,262 & \\
\hline Adj $R^{2}$ & & 0.45 & & 0.58 & \\
\hline Variables & Pred sign & Coef. Est & t-statistics & Coef. Est & t-statistics \\
\hline \multicolumn{6}{|l|}{ Low EM firms } \\
\hline EPS & + & 8.336 & $12.80^{* * *}$ & 4.308 & $6.70^{* * *}$ \\
\hline STRING $x$ EPS & + & 1.486 & $18.21^{* * *}$ & 1.961 & $24.16^{* * *}$ \\
\hline EVAR x EPS & - & -0.592 & $-19.54^{* * *}$ & -0.706 & $-30.66^{* * *}$ \\
\hline GROWTH x EPS & + & -0.338 & $-1.99^{* * *}$ & 0.153 & 1.06 \\
\hline LEVERAGE $x$ EPS & - & -0.617 & $-23.97^{* * *}$ & -0.285 & $-12.04^{* * *}$ \\
\hline BVE & + & & & 0.543 & $58.58^{* * *}$ \\
\hline Year effect & & Included & & Included & \\
\hline Number of observations & & 95,086 & & 94,981 & \\
\hline Adj $R^{2}$ & & 0.41 & & 0.58 & \\
\hline
\end{tabular}

\section{Notes to Table 14}

Table 14 reports the results of price regressions when earnings string firms engage in income-increasing earnings management. Panel A compares differences in the valuation premium within the earnings string sample. EM X EPS is the interaction variable to partition earnings string firms that engage in incomeincreasing earnings management and earnings string firms that do not. EM is the earnings management variable and is measured based on the firm's discretionary accruals (in model 1) or a dummy variable denoting 1 when the firm reports positive discretionary accruals and 0 otherwise (in model 2). Panel B partitions the earnings string firms into high and low EM earnings string firms respectively. The regressions measure the valuation premium accruing to high/low EM firms in the last year of their earnings string period relative to the benchmark sample of non-earnings string firms. All other variables are defined in Table 13. ${ }^{* * *} / * * *$ denotes significance levels at the $1 \%, 5 \%$ and $10 \%$ level (two-tailed) respectively. 


\section{Further Analysis}

I perform several additional tests of the hypotheses and sensitivity checks to assess the robustness of my results. I examine changes in the level of pre-managed earnings in my earnings string sample to assess whether firms would report an earnings increase in the absence of accruals management. I also examine whether the evidence of income-increasing earnings management in the last year of the earnings string (i.e., a multi-period setting) is distinct from the notion of a period-by-period attempt to meet or beat earnings targets (i.e., a single period setting). I perform additional analyses to relate my results to prior research that analyzes small EPS changes, and I assess why managers would want to engage in income-increasing earnings management in the last year of the earnings string if they anticipate that the string will break the following year. In additional robustness tests, I consider how share repurchases affect my results. I also vary my benchmark samples to test the robustness of my earnings management test results. Finally, I examine whether the exclusion of loss firms would increase the power of my tests and the effects of changing the definition of an earnings string to four or five years instead of three years. 


\subsection{Analysis of changes in pre-managed earnings}

The main results in my earnings management tests suggest managers engage in incomeincreasing earnings management in the last year of an earnings string, consistent with hypothesis 1. However, it is not clear whether, on average, the magnitude of income-increasing earnings management is such that it converts an earnings decrease in the last year of the earnings string period to an earnings increase. I perform additional tests to assess the relation between the magnitude of accruals management and the magnitude of pre-managed earnings changes. I convert the firm's modified Jones model discretionary accruals to a per share basis. I obtain a measure of pre-managed EPS for each firm in each year by subtracting the firm's discretionary accruals per share from its reported earnings per share.

Panel A of Table 15 shows the proportion of earnings string firms that would have reported an earnings increase in the absence of earnings management. I analyze the pattern of pre-managed EPS changes in two ways. I first show the proportion of firms whose current year's pre-managed EPS are higher than last year's pre-managed EPS. These are firms with positive premanaged EPS growth. My results show that the proportion of firms with positive pre-managed EPS changes decrease as these firms reach the end of their earnings strings. 63.4 percent (56.5 percent) of earnings string firms have positive pre-managed EPS growth in year $t-3$ (year $t-1$ ).

I also examine the proportion of firms that would have reported a decrease in reported EPS in the absence of income-increasing earnings management. I compute whether the change in reported EPS would remain positive in the last year of the earnings string period by subtracting 
firms' discretionary accruals per share in the current year from the change in reported EPS between the current and previous year. I find that 73.4 percent of firms would have reported a negative change in reported EPS in the last year of the earnings string if they have not engaged in income-increasing earnings management. The other 26.6 percent of firms would still be able to report an EPS increase even if they had not used income-increasing earnings management.

I next compare the median values of changes in reported EPS with the firms' corresponding median values of discretionary accruals per share (Panel B, Table 15). I report my results using median values and not mean values because there is considerable skewness (7.234) in the distribution of reported EPS change. For all earnings string firms, the median change in reported EPS in each of the last three years of the earnings string is between $\$ 0.17-\$ 0.18$. The median discretionary accruals per share in years $t-3$ and $t-2$ are $-\$ 0.03$ and $-\$ 0.01$, increasing to $\$ 0.04$ in year $t-1$, consistent with my earlier earnings management test results that show managers engage in income-increasing earnings management toward the end of their earnings strings.

When I partition my sample firms into firms with versus without an earnings shortfall in the absence of accruals management, I find that the median change in reported EPS for firms that would have reported an earnings shortfall is around $\$ 0.13-\$ 0.15$ in each of the last three years of the earnings string period. The discretionary accruals per share required to prevent these firms from reporting an earnings decrease increase from $\$ 0.21$ in year $t-3$ to $\$ 0.39$ in year $t-1$. Even through the change in reported EPS is relatively consistent in the last three years, managers of 
earnings string firms need to engage in more income-increasing earnings management as the level of reported EPS is higher in year $t-1$ compared to year $t-3$. Eventually, if their firms' premanaged earnings do not improve and it is not possible for managers to engage in further income-increasing earnings management, the earnings string pattern breaks.

Panel B of Table 15 also show that firms without an earnings shortfall appear to manage earnings downwards. Specifically, for these firms, their median change in reported EPS is $\$ 0.20$ $\$ 0.21$ in each of the last three years of the earnings string period. These firms would have reported a higher EPS if their managers have not engaged in income-decreasing accruals management (\$0.12-\$0.17). The results in this test are consistent with Myers et al.'s (2007) findings that earnings string firms engage in income-smoothing during the earnings string period. 
Table 15: Analysis of Pre-managed Earnings Changes

Panel A: Frequency distribution of pre-managed earnings increases

\begin{tabular}{|c|c|c|c|}
\hline & $\underline{\text { Year } t-1}$ & $\underline{\text { Year } t-2}$ & $\underline{\text { Year } t-3}$ \\
\hline \multicolumn{4}{|c|}{$\frac{\text { Pre-managed EPS growth }}{\left(\mathrm{EPS}_{t}-\mathrm{DA}_{t}\right)-\left(\mathrm{EPS}_{t-1}-\mathrm{DA}_{t-1}\right)}$} \\
\hline Negative & $43.5 \%$ & $38.6 \%$ & $36.6 \%$ \\
\hline Positive & $56.5 \%$ & $61.4 \%$ & $63.4 \%$ \\
\hline \multicolumn{4}{|c|}{$\begin{array}{l}\text { Change in reported EPS in the absence of accruals management } \\
\left(\triangle \mathrm{EPS}_{t}-\mathrm{DA} t\right)\end{array}$} \\
\hline Negative & $73.4 \%$ & $67.5 \%$ & $64.2 \%$ \\
\hline Positive & $26.6 \%$ & $32.5 \%$ & $35.8 \%$ \\
\hline
\end{tabular}

Panel B: Magnitude of EPS and discretionary accruals per share

\begin{tabular}{|c|c|c|c|}
\hline All earnings string firms & $\underline{\text { Year } t-1}$ & $\underline{\text { Year } t-2}$ & $\underline{\text { Year } t-3}$ \\
\hline Change in reported EPS & 0.17 & 0.18 & 0.17 \\
\hline Discretionary accrual per share & 0.04 & -0.01 & -0.03 \\
\hline
\end{tabular}

Firms with earnings shortfall in the absence of accruals management

$\begin{array}{llll}\text { Change in reported EPS } & 0.13 & 0.15 & 0.14 \\ \text { Discretionary accrual per share } & 0.39 & 0.29 & 0.21\end{array}$

Firms without earnings shortfall in the absence of accruals management

$\begin{array}{lccc}\text { Change in reported EPS } & 0.21 & 0.21 & 0.20 \\ \text { Discretionary accrual per share } & -0.12 & -0.15 & -0.17\end{array}$

\section{Notes to Table 15}

Table 15 provides analysis of the earnings string firms' pre-managed EPS in the absence of accruals management. Panel A provides the frequency distribution of the earnings string firms' pre-managed EPS growth, and the annual change in reported EPS adjusted for the magnitude of income-increasing earnings management in that year. Panel B provides descriptive statistics of the annual change in reported EPS and the corresponding discretionary accruals per share. A firm is classified as having an earnings shortfall if its current year's pre-managed earnings is lower than last year's pre-managed earnings. Discretionary accrual per share is computed by converting the firm's modified Jones model's discretionary accruals to a per share basis. Change in EPS and discretionary accruals (DA) per share are based on median values measured in dollars. See appendix for variable definitions. 
I also perform an alternative test to examine whether firms' fundamentals correspond with the need for managers to engage in income-increasing earnings management. That is, I would expect firms that repeatedly engage in income-increasing earnings management to do so because they experience earnings shortfalls during the earnings string periods. Table 16 reports my analysis of high and low EM earnings string firms. As before, I define a high EM earnings string if the firm engages in income-increasing earnings management more than half the years in the earnings string period. I examine whether high EM earnings string firms have poor fundamental performance relative to low EM earnings string firms (Panel B). My results show that high EM firms report higher ROA (1 percent higher) and higher sales growth (2-4 percent higher), have higher debt/assets ratios (3-4 percent higher), but they are smaller (based on total assets), and earn lower market-adjusted stock returns (2-4 percent lower than low EM firms).

The above results do not necessarily imply that high EM firms have stronger fundamentals, because the reported figures include the effect of accruals management. To isolate the effect of accruals management (Panel A), I examine whether there are fewer (more) high EM firms than low EM firms when earnings string firms have (do not have) consistently increasing pre-managed earnings growth. I find this to be the case. Specifically, there are fewer high EM firms (263 firms) than low EM firms (459 firms) when the firms' pre-managed earnings are growing, and there are more high EM firms $(5,250$ firms) than low EM firms $(4,590)$ for firms that do not experience consistent growth in their pre-managed earnings in the last three years of the earnings string period. The difference is significant $\left(\chi^{2}=77.24, \mathrm{p}<0.001\right)$. 
Table 16: Analysis of High/Low EM Earnings String Firms

Panel A: Frequency analysis

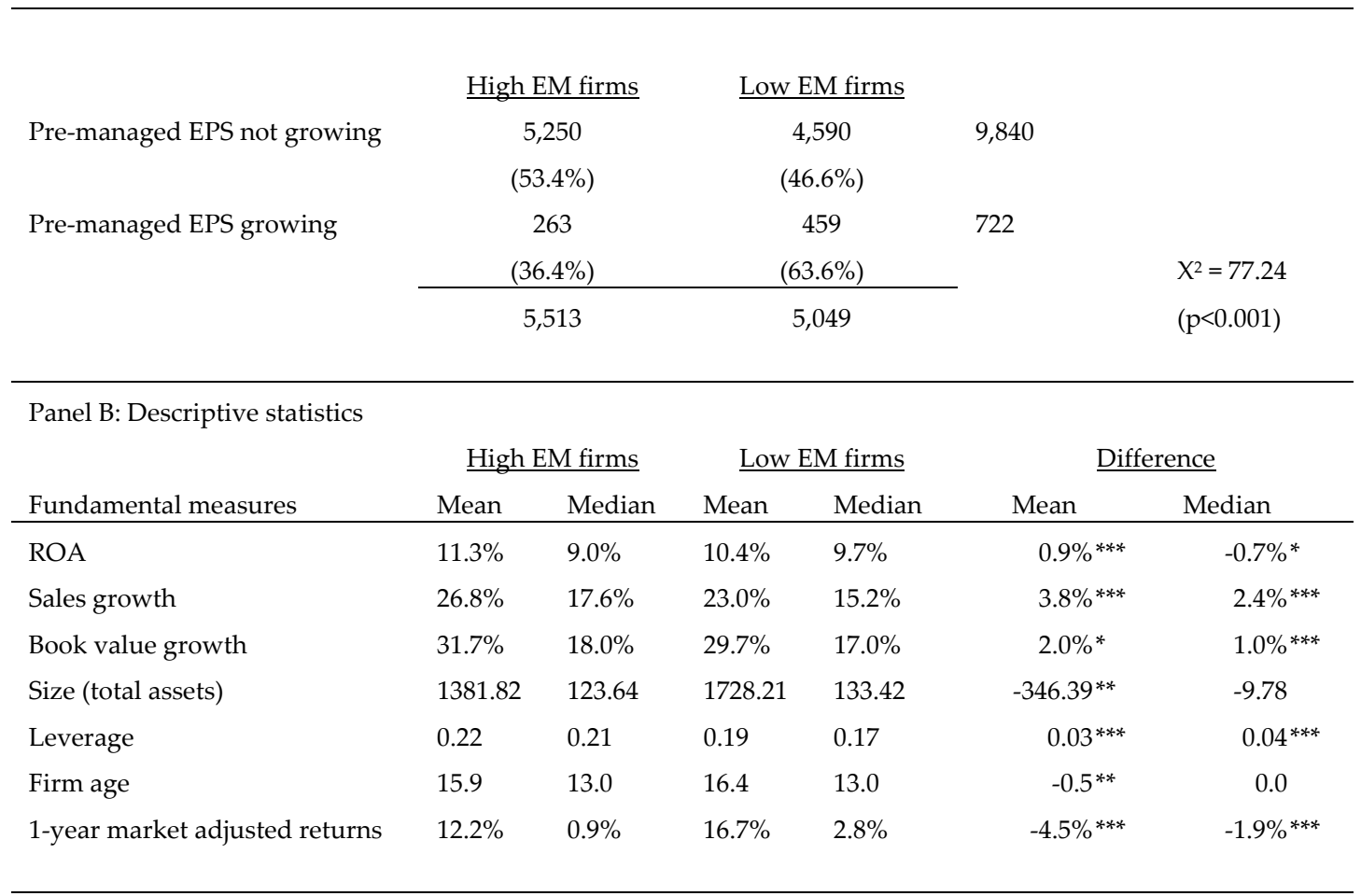

Notes to Table 16

Table 16 compares whether high EM earnings string firms are significantly different from low EM earnings string firms. All observations are based on earnings string firm-year observations at the end of the earnings string period. Panel A provides the frequency analysis of high/low EM firms interacted with pre-managed earnings growth. A firm is classified as reporting growing premanaged EPS if it reports consecutive pre-managed EPS growth in the last three years of the earnings string period. A firm is classified as high EM firm if it engages in income-increasing earnings management more than half the years in the earnings string period. Panel B provides descriptive statistics of various fundamental measures for the high/low EM firms. 1-year market adjusted return is the buy-and-hold stock's return less the value-weighted market return measured over the firm's fiscal year period. ${ }^{* * * * *} / *$ denotes significance levels at the $1 \%, 5 \%$ and $10 \%$ level (two-tailed) respectively. See appendix for variable definitions. 
Finally, I also consider the sensitivity of earnings management tests to excluding firms with consistent pre-managed earnings growth. I use an unrestricted sample so as to be able to make inferences about the earnings management behavior of earnings string firms in general. I expect to find stronger results for my earnings management tests when I restrict my sample to firms whose pre-managed earnings are not growing. However, when I exclude earnings string firms whose pre-managed earnings have been increasing in the last three years of their earnings string period (722 firms), I do not find stronger results in my earnings management tests. I also use consecutive sales growth in the last three years of the earnings string period as an alternative proxy for pre-managed earnings growth to partition my earnings string sample. Again, I do not find that my results are stronger compared with the full earnings string sample.

One possible interpretation of these results is that income-increasing earnings management is not restricted to firms with poor performance. Thus, a manager might want to engage in income-increasing earnings management even if pre-managed earnings growth is positive (for example, if managers would like to report 10 percent growth in EPS instead of 5 percent growth in EPS). That is, not all managers with earnings strings explicitly seek to report small consecutive EPS increases throughout the earnings string period. 


\subsection{Analysis of changes in string length}

My hypothesis is built on the premise that managers of earnings string firms engage in income-increasing earnings management to sustain their earnings strings. I consider whether the patterns of income-increasing earnings management that I document for earnings string firms also appear for firms that do not have an earnings string pattern.

Table 17 reports the magnitude of discretionary accruals and performance-adjusted discretionary accruals for firms with varying lengths of earnings strings. String=1 refers to firmyear observations that do not report an earnings increase in the previous year but report an earnings increase in the current year. String=2 refers to firm-year observations that start to build an earnings string; they have one earnings increase in the previous year and one earnings increase in the current year. String=3 onwards are earnings string firms in my sample with varying lengths of successive annual EPS increases.

I first show that when firms do not face an impending earnings decrease the following year (the "no-break sample"), managers, on average, do not use much income-increasing earnings management regardless of the previous length of earnings increases (column 1 of Table 17). The magnitudes of discretionary accruals and adjusted discretionary accruals are consistently below 1 percent of total assets. Discretionary accruals are higher as the string of earnings increases lengthens, consistent with the well-documented relation between discretionary accruals and accounting performance. However, performance-adjusted discretionary accruals appear to be effective in reducing the performance related bias. 
When firms face an earnings decrease the following year (column 2 of Table 17), there is consistent evidence of income-increasing earnings management for earnings string firms with string $=3$ onwards. For firms with string $=1$, there is no evidence of earnings management. For firms with string=2, the mean but not the median values of discretionary accruals and performance-adjusted discretionary accruals are reliably non-zero at the 0.01 level. These results are broadly consistent with the results in my main tests; that is, the impending earnings decrease would have occurred earlier had managers not intervened in the financial reporting process to delay the reporting of an earnings decrease. The results in this test thus suggest that my findings relate more to a multi-period setting than to a single-period setting. That is, managers seek to maintain an unbroken record of earnings increases and they apparently consider previous financial performance in deciding whether to engage in income-increasing earnings management in the current year. 
Table 17: Earnings Management Variables - Various String Length

\begin{tabular}{|c|c|c|c|c|}
\hline & \multicolumn{2}{|c|}{$\underline{\text { No Break }}$} & \multicolumn{2}{|c|}{$\underline{\text { Impending Break }}$} \\
\hline & Mean & Median & Mean & Median \\
\hline \multicolumn{5}{|l|}{ String=1 } \\
\hline Discretionary accruals & -0.011 & -0.012 & -0.003 & -0.006 \\
\hline Performance adjusted DA & -0.012 & -0.010 & -0.006 & -0.004 \\
\hline \multicolumn{5}{|l|}{ String $=2$} \\
\hline Discretionary accruals & 0.000 & -0.004 & $0.009^{* * *}$ & 0.002 \\
\hline Performance adjusted DA & -0.001 & -0.003 & $0.008^{* * *}$ & 0.002 \\
\hline \multicolumn{5}{|l|}{$\underline{\text { String }=3}$} \\
\hline Discretionary accruals & $0.004^{* * *}$ & -0.001 & $0.011^{* * *}$ & $0.004^{* * *}$ \\
\hline Performance adjusted DA & $0.002^{*}$ & -0.002 & $0.008^{* * *}$ & $0.003^{* *}$ \\
\hline \multicolumn{5}{|l|}{$\underline{\text { String }=4}$} \\
\hline Discretionary accruals & $0.008^{* * *}$ & $0.002^{* * *}$ & $0.017^{* * *}$ & $0.009^{* * *}$ \\
\hline Performance adjusted DA & $0.004^{* * *}$ & 0.000 & $0.013^{* * *}$ & $0.006^{* * *}$ \\
\hline \multicolumn{5}{|l|}{ String $=5$} \\
\hline Discretionary accruals & $0.010^{* * *}$ & $0.004^{* * *}$ & $0.023^{* * *}$ & $0.013^{* * *}$ \\
\hline Performance adjusted DA & $0.004^{* * *}$ & 0.000 & $0.016^{* * *}$ & $0.009^{* * *}$ \\
\hline
\end{tabular}

Notes to Table 17

Table 17 reports the mean and median discretionary accruals based on the length of the earnings string. String $=\mathrm{n}$ refers to the number of years a firm reports an annual EPS increase over its previous year. "No break" refers to earnings string firm-year observations that do not report an annual EPS decrease in the following year. "Impending break" refers to earnings string firm-year observations that break their earnings string pattern in the following year. Discretionary accruals (DA) are determined using the cross-sectional variation of the modified Jones model. Performance adjusted discretionary accruals are calculated by controlling for ROA in the first stage of the modified Jones model based on Kothari, Leone and Wasley (2005). *****/* denotes significance levels at the $1 \%, 5 \%$ and $10 \%$ level (two-tailed) respectively using t-tests for means and Wilcoxon tests for medians. 


\subsection{Analysis of small EPS changes}

Prior research has documented evidence of income-increasing earnings management when firms report small EPS changes. I redo my analysis of breaks in earnings strings on samples segmented by the size of the earnings increase in the pre-break year. I sort my sample into quintiles on the EPS increase in the last year of the earnings string period, and estimate equation (1) separately for the smallest and largest EPS change quintiles. Results are in Table 18. I find stronger evidence of income-increasing earnings management when the earnings increase in the pre-break year is small (Panel A) than when the earnings increase in the pre-break year is large (Panel B). Specifically, for the quintile of earnings string firms with the smallest EPS change, the coefficient for PREBREAK1 is 0.035 (t-statistic: 11.40, $\mathrm{p}<0.001), 0.027$ (t-statistic: 7.99, $\mathrm{p}<0.001$ ) and 0.014 (t-statistic: $3.25, \mathrm{p}<0.001$ ) for the first, second and third earnings string samples respectively using discretionary accruals as the dependent variable. The results are similar when I use performance-adjusted discretionary accruals (model 2). The coefficient for PREBREAK1 is 0.028 (t-statistic: 9.66, p<0.001), 0.022 (t-statistic: 6.86, $\mathrm{p}<0.001$ ) and 0.011 (t-statistic: 2.51, $\mathrm{p}<0.001$ ) for the first, second and third earnings string samples respectively.

Among firms in the largest quintile of EPS change, the coefficient on PREBREAK1 is 0.012 (0.011) in model 1 (model 2) versus 0.035 (0.028) for the small EPS change quintile in the first earnings string sample. The results are not statistically significant at the 0.10 level for largest EPS change quintile in both the second and third earnings string samples. Specifically, the coefficient for PREBREAK1 is 0.007 (t-statistic: 1.17) and 0.005 (t-statistic: 0.63 ) for the large EPS 
change quintile in the second and third earnings string samples respectively using discretionary accruals as the dependent variable. The results in this test provide further evidence that managers engage in income-increasing earnings management if they are able to turn a small EPS decrease to a small EPS increase.

I also test whether conditioning my sample based on the magnitude of the earnings decrease in the year of the earnings break affects results of my earnings management constraint tests. I do not find this to be so (results not tabulated). One possible explanation for the null result is that the availability of balance sheet flexibility in the earnings string sample is conditioned on the extent of balance sheet flexibility used in prior years when managers bridge the gap between their firms' pre-managed earnings and their actual reported EPS. 
Table 18: Earnings Management Regressions - Small EPS Change

Panel A: First earnings string sample

\begin{tabular}{|c|c|c|c|c|c|}
\hline Variables & Pred. sign & Coef. Est & t-statistics & Coef. Est & t-statistics \\
\hline & & Model 1 & & Model 2 & \\
\hline \multicolumn{6}{|l|}{$\underline{\text { Small EPS change }}$} \\
\hline PREBREAK1 & + & 0.035 & $11.40^{* * *}$ & 0.028 & $9.66^{* * *}$ \\
\hline PREBREAK2 & + & 0.014 & $4.18^{* * *}$ & 0.010 & $3.10^{* * *}$ \\
\hline PREBREAK3 & $?$ & 0.006 & 1.47 & 0.005 & 1.30 \\
\hline BEGSTRING & $?$ & 0.007 & $2.77^{* * *}$ & 0.004 & $1.67^{*}$ \\
\hline SIZE & $?$ & 0.001 & $2.98^{* * *}$ & 0.000 & 1.02 \\
\hline LEVERAGE & + & 0.060 & $28.54^{* * *}$ & 0.061 & $31.74^{* * *}$ \\
\hline GROWTH & + & 0.051 & $29.83^{* * *}$ & 0.043 & $28.32^{* * *}$ \\
\hline FIRM AGE & $?$ & 0.005 & $9.64^{* * *}$ & 0.005 & $9.22^{* * *}$ \\
\hline Number of observations & & 113,583 & & 113,514 & \\
\hline Adj $R^{2}$ & & 0.026 & & 0.024 & \\
\hline \multicolumn{6}{|l|}{ Large EPS change } \\
\hline PREBREAK1 & + & 0.012 & $2.77^{* * *}$ & 0.011 & $2.83^{* * *}$ \\
\hline PREBREAK2 & + & -0.002 & -0.45 & 0.001 & 0.34 \\
\hline PREBREAK3 & $?$ & -0.003 & -0.73 & 0.000 & -0.03 \\
\hline BEGSTRING & $?$ & -0.003 & -0.65 & -0.001 & -0.15 \\
\hline SIZE & $?$ & 0.001 & $2.77^{* * *}$ & 0.000 & $0.65^{* * *}$ \\
\hline LEVERAGE & + & 0.061 & $28.84^{* * *}$ & 0.062 & $31.92^{* * *}$ \\
\hline GROWTH & + & 0.051 & $30.31^{* * *}$ & 0.044 & $28.75^{* * *}$ \\
\hline FIRM AGE & $?$ & 0.005 & $9.49^{* * *}$ & 0.005 & $9.25^{* * *}$ \\
\hline Number of observations & & 113,468 & & 113,400 & \\
\hline Adj $R^{2}$ & & 0.026 & & 0.024 & \\
\hline
\end{tabular}




\section{Table 18 (Continued)}

Panel B: Second earnings string sample

\begin{tabular}{|c|c|c|c|c|c|}
\hline Variables & Pred. sign & Coef. Est & t-statistics & Coef. Est & t-statistics \\
\hline & & Model 1 & & Model 2 & \\
\hline \multicolumn{6}{|l|}{$\underline{\text { Small EPS change }}$} \\
\hline PREBREAK1 & + & 0.027 & $7.99^{* * *}$ & 0.022 & $6.86^{* * *}$ \\
\hline PREBREAK2 & + & 0.007 & $1.88^{*}$ & 0.001 & 0.31 \\
\hline PREBREAK3 & $?$ & 0.000 & 0.05 & 0.000 & 0.11 \\
\hline BEGSTRING & $?$ & 0.004 & $1.84^{*}$ & 0.002 & 0.97 \\
\hline SIZE & $?$ & 0.001 & $2.81^{* * *}$ & 0.000 & 0.85 \\
\hline LEVERAGE & + & 0.060 & $28.24^{* * *}$ & 0.061 & $31.32^{* * *}$ \\
\hline GROWTH & + & 0.051 & $29.68^{* * *}$ & 0.043 & $28.22^{* * *}$ \\
\hline FIRM AGE & $?$ & 0.005 & $9.49^{* * *}$ & 0.005 & $9.17^{* * *}$ \\
\hline Number of observations & & 111,805 & & 111,737 & \\
\hline Adj $R^{2}$ & & 0.026 & & 0.024 & \\
\hline \multicolumn{6}{|l|}{ Large EPS change } \\
\hline PREBREAK1 & + & 0.007 & 1.17 & 0.008 & 1.39 \\
\hline PREBREAK2 & + & -0.007 & -1.33 & -0.003 & -0.73 \\
\hline PREBREAK3 & $?$ & -0.002 & -0.45 & 0.003 & 0.61 \\
\hline BEGSTRING & $?$ & -0.010 & -1.57 & -0.008 & -1.21 \\
\hline SIZE & $?$ & 0.001 & $2.90^{* * *}$ & 0.000 & -0.84 \\
\hline LEVERAGE & + & 0.060 & $28.41^{* * *}$ & 0.061 & $31.44^{* * *}$ \\
\hline GROWTH & + & 0.051 & $29.77^{* * *}$ & 0.043 & $28.27^{* * *}$ \\
\hline FIRM AGE & $?$ & 0.005 & $9.46^{* * *}$ & 0.005 & $9.16^{* * *}$ \\
\hline Number of observations & & 110,944 & & 110,876 & \\
\hline Adj $R^{2}$ & & 0.026 & & 0.024 & \\
\hline
\end{tabular}




\section{Table 18 (Continued)}

Panel C: Third earnings string sample

\begin{tabular}{|c|c|c|c|c|c|}
\hline Variables & Pred. sign & Coef. Est & t-statistics & Coef. Est & t-statistics \\
\hline & & Model 1 & & Model 2 & \\
\hline \multicolumn{6}{|l|}{$\underline{\text { Small EPS change }}$} \\
\hline PREBREAK1 & + & 0.014 & $3.25^{* * *}$ & 0.011 & $2.51^{* * *}$ \\
\hline PREBREAK2 & + & 0.001 & 0.12 & 0.000 & 0.09 \\
\hline PREBREAK3 & $?$ & -0.001 & -0.19 & 0.000 & 0.06 \\
\hline BEGSTRING & $?$ & -0.002 & -0.53 & 0.000 & 0.10 \\
\hline SIZE & $?$ & 0.001 & $2.97^{* * *}$ & 0.000 & 1.02 \\
\hline LEVERAGE & + & 0.059 & $27.92^{* * *}$ & 0.060 & $30.89^{* * *}$ \\
\hline GROWTH & + & 0.051 & $29.58^{* * *}$ & 0.043 & $28.12^{* * *}$ \\
\hline FIRM AGE & $?$ & 0.005 & $9.45^{* * *}$ & 0.005 & $9.17^{* * *}$ \\
\hline Number of observations & & 110,515 & & 110,447 & \\
\hline Adj $R^{2}$ & & 0.025 & & 0.023 & \\
\hline \multicolumn{6}{|l|}{ Large EPS change } \\
\hline PREBREAK1 & + & 0.005 & 0.63 & 0.005 & 0.75 \\
\hline PREBREAK2 & + & -0.005 & -0.67 & -0.003 & -0.35 \\
\hline PREBREAK3 & $?$ & 0.003 & 0.48 & 0.008 & 1.26 \\
\hline BEGSTRING & $?$ & 0.002 & 0.23 & 0.005 & 0.59 \\
\hline SIZE & $?$ & 0.001 & $2.94^{* * *}$ & 0.000 & 0.97 \\
\hline LEVERAGE & + & 0.059 & $27.91^{* * *}$ & 0.060 & $30.88^{* * *}$ \\
\hline GROWTH & + & 0.051 & $29.59^{* * *}$ & 0.043 & $28.14^{* * *}$ \\
\hline FIRM AGE & $?$ & 0.005 & $9.49^{* * *}$ & 0.005 & $9.19^{* * *}$ \\
\hline Number of observations & & 109,978 & & 109,910 & \\
\hline Adj $R^{2}$ & & 0.025 & & 0.023 & \\
\hline
\end{tabular}

\section{Notes to Table 18}

Table 18 reports the results of both pooled and Fama-MacBeth regressions of the earnings management tests. Model 1 uses the modified Jones model discretionary accruals as the dependent variable. Model 2 uses the performance-adjusted modified Jones model discretionary accruals as the dependent variable. $t$ statistics for the pooled regressions are calculated using Newey-West standard errors corrected for autocorrelation and heteroskedasticity. t-statistics for the Fama-MacBeth regressions are calculated using the standard error of the mean coefficient estimates across years. The sample period for the regression tests spans 1952-2005. The earnings string sample of small (large) EPS change consists of earnings string firms in the lowest (highest) quintile of EPS change in the year before the earnings string break. The benchmark sample is consisted of all Compustat firm-year observations between 1951-2006 (excluding banks and utilities and the earnings string sample). ${ }^{* *} / * * / *$ denotes significance levels at the $1 \%, 5 \%$ and $10 \%$ level (two-tailed) respectively. See appendix for variable definitions. 


\subsection{Analysis of firms' business uncertainty}

If managers of earnings string firms are able to stretch their earnings strings via accruals management for, at most, one to two years, why would they want to do so, under the assumption that they know the earnings string will eventually end regardless of their earnings management efforts? I propose three reasons why managers would resort to income-increasing earnings management to delay the break in the earnings string pattern, despite having anticipated that the earnings string pattern will break soon. First, managers may seek to delay the break in the earnings string pattern for opportunistic reasons. Research provides evidence that managers exercise more stock options during periods of high accruals (Bartov and Mohanram 2004; Bergstresser and Philippon 2006; Sawicki and Shrestha 2008). Two other papers examine whether the relation between insider selling and earnings management is more pronounced in periods preceding poor firm performance. Beneish, Press and Vargus (2004) find evidence that managers engage in managing earnings upwards following abnormally high levels of insider selling, to distance their selling from the subsequent revelation of bad news. McVay, Nagar and Tang (2006) find evidence that when firms meet (or beat) earnings thresholds, managers sell their shares, consistent with Ke et al.'s (2003) findings that insiders sell their shares prior to the break in the earnings string pattern (i.e., when the firms are still beating earnings targets).

Second, even if managers do not engage in insider selling, they may want to prolong the earnings string period for an additional year or two (even when they anticipate that the earnings string pattern will subsequently collapse) if they are fixated on short-term performance. The 
managerial myopia literature provides several explanations why managers would prefer to extend an earnings string even when there is a decay in performance. Graham et al. (2005) state that managers in their survey claim they have to balance the trade-off between the short-term need to beat earnings targets against the long-term objective of making value-maximizing decisions because of pressures from stakeholders. Hence, managers are willing to sacrifice longterm future performance if they can achieve short-term earnings targets.

Drawing from prior research on managerial myopia, Cheng, Subramanyam and Zhang (2007) provide two conditions as to when managers develop myopic corporate behavior. First, managers must be motivated to overweight the current market value of the firm and be unwilling to adopt a long-term perspective. Overweighting the current market value might occur if managers are under threat of takeovers, have high-powered equity incentives, have an urgent need to raise capital or have career concerns that are incompatible with taking a long-term view (horizon problem). Several of these reasons are consistent with the arguments I use in this paper. Second, managers expect that the capital market would misprice current earnings. Mispricing occurs if investors have a short term focus, misunderstand the persistence of earnings or do not fully consider the firm's underlying economics. Even if mispricing does not occur, Stein (1989) shows analytically that managerial myopia behavior can result as long as managers believe that the markets can be fooled.

Finally, managers may be overconfident (or optimistic) in their abilities to turn around a faltering business. The overconfidence literature generally shows that people exhibit 
overconfidence in judgment (Einhorn and Hogarth 1978; Kahneman, Slovic and Tversky 1982; Heath and Tversky 1991). Ben-David, Graham and Harvey (2007) find that managers (CFOs) are also overconfident in their abilities on average, and that they are more confident following periods of strong performance. Ex-ante, even when managers correctly anticipate that their firms' earnings string patterns might break, they may be hoping for a change in economic conditions or are confident that they can engineer a turnaround. Either of these beliefs would be supported by greater uncertainty about future outcomes when firms approach the end of an earnings string.

To test whether earnings string firms at the end of their patterns experience greater uncertainty about future outcomes, I use both ex-post measures of uncertainty (variability of sales) and ex-ante measures (dispersion of analyst forecasts). I measure a firm's variability of sales each year based on the standard deviation of its annual sales per share in the last three years. I also use the standard deviation of quarterly changes in sales per share as an alternative measure. I measure dispersion of analyst forecasts based on the standard deviation of one-year ahead analyst's EPS forecast as well as the standard deviation of analysts' predictions of the firm's long term growth rate using analyst forecast data in the IBES database.

Table 19 reports the measures of business conditions for the earnings string firms. Panel A provides a time-series analysis comparing the volatility measures in year $t-1$ versus year $t-3$. Results are mixed. There is greater dispersion in analyst one-year ahead forecast at year $t-1$ compared to year $t-3$, significant at the 0.05 level. The variability in sales in year $t-1$ is also higher than in year $t-3$, whether measured in a three-year rolling period or using a one-year measure 
based on seasonally adjusted changes in quarterly sales per share, and the change is significant at the 0.01 level. There is less dispersion in analyst forecast of long term growth in year $t-1$ compared with year $t-3$, significant at the 0.10 level for the mean forecast but not for median forecast. Overall, the results provide mixed support to suggest that managers of earnings string firms may be more inclined to manage earnings upwards at the end of the earnings string period because they are hoping for a good outcome in the next period.

Panel B of Table 19 provides cross-sectional analysis of high EM earnings string firms and low EM earnings string firms. There is no statistically reliable difference in the dispersion of analyst forecasts between high EM firms and low EM firms. For the sales variability measures, the results show that there is greater variability for high EM firms compared to low EM firms based on median changes using a three-year rolling period (0.278) and quarterly changes in sales (0.028), significant at the 0.01 level. However, there is no statistically reliable difference in the variability of sales based on mean changes.

Overall, I obtain mixed support that managers attempt to use income-increasing earnings management hoping for a shift in business conditions (as predicted in Degeorge et al.'s twoperiod model of earnings management discussed in section 2.1). The results suggest that firms at the end of their earnings string periods experience greater volatility in sales and dispersion in one-year ahead analyst forecasts but not for analyst long-term forecasts.

Finally, I do not find evidence of a positive association between uncertainty and earnings management apart from median differences in the variability of sales. The statistical correlation 
between uncertainty and earnings management measures is also not significant (not tabulated). I interpret this finding to suggest that managers of earnings string firms do not mechanically engage in income-increasing earnings management to take advantage of higher volatility in business conditions. Thus, it is not necessarily the case that firms that manage earnings the most (high EM firms) are subject to greater post-break earnings variability than low EM firms. 


\section{Table 19: Changes in Firms' Business Uncertainty}

\begin{tabular}{|c|c|c|c|c|c|c|}
\hline \multirow{2}{*}{$\begin{array}{l}\text { Panel A: Time series analysis } \\
\text { Pre-break volatility }\end{array}$} & \multicolumn{2}{|c|}{$\underline{\text { Year } t-1}$} & \multicolumn{2}{|c|}{$\underline{\text { Year } t-3}$} & \multicolumn{2}{|c|}{ Difference $(t-1$ vs $t-3)$} \\
\hline & $\underline{\text { Mean }}$ & $\underline{\text { Median }}$ & $\underline{\text { Mean }}$ & $\underline{\text { Median }}$ & $\underline{\text { Mean }}$ & $\underline{\text { Median }}$ \\
\hline Dispersion - LT analyst forecast & 4.049 & 2.900 & 4.281 & 3.000 & $-0.232^{*}$ & -0.100 \\
\hline Dispersion - 1-year ahead analyst forecast & 0.161 & 0.080 & 0.149 & 0.080 & $0.012^{* *}$ & $0.000^{* *}$ \\
\hline Variability of sales -3 years rolling period & 8.462 & 2.243 & 7.095 & 1.556 & $1.367^{* * *}$ & $0.687^{* * *}$ \\
\hline Variability of sales - quarterly change & 8.433 & 0.347 & 7.277 & 0.284 & 1.156 & $0.063^{* * *}$ \\
\hline Panel B: Cross-sectional analysis & High E & M firms & $\underline{\text { Low E }}$ & M firms & Difference & $e(t-1$ vs $t-3)$ \\
\hline$\underline{\text { Post-break volatility }}$ & $\underline{\text { Mean }}$ & $\underline{\text { Median }}$ & $\underline{\text { Mean }}$ & $\underline{\text { Median }}$ & $\underline{\text { Mean }}$ & $\underline{\text { Median }}$ \\
\hline Dispersion - LT analyst forecast & 4.225 & 3.300 & 4.049 & 3.180 & 0.176 & 0.120 \\
\hline Dispersion - 1-year ahead analyst forecast & 0.194 & 0.120 & 0.207 & 0.120 & -0.013 & 0.000 \\
\hline Variability of sales -3 years rolling period & 8.085 & 2.275 & 8.118 & 1.997 & -0.033 & $0.278^{* * *}$ \\
\hline Variability of sales - quarterly change & 7.622 & 0.358 & 9.544 & 0.330 & -1.922 & $0.028^{* * *}$ \\
\hline
\end{tabular}

\section{Notes to Table 19}

Table 19 reports descriptive statistics of the earnings string firms' volatility measures. Analyst forecast data is obtained from IBES database between 1975-2006. Annual sales data is obtained from Compustat database between 1951-2006. Quarterly sales data is available on Compustat database after 1961. Panel A presents a time-series comparison of earnings string firms' volatility measures in year $\mathrm{t}-1$ (the last year of the earnings string period) versus year $\mathrm{t}-3$ for the full sample of earnings string firms. Panel B presents a cross-sectional comparison of the post-break volatility measures of earnings string firms that engage in income-increasing earnings management more than half the years during their earnings string periods (high EM firms) versus earnings string firms that engage in income-increasing earnings management less than half the years of their earnings string periods (low EM firms). ${ }^{* *} /{ }^{* *} /{ }^{*}$ denotes significance levels at the $1 \%, 5 \%$ and $10 \%$ level (two-tailed) respectively based on t-tests for differences in means and Wilcoxon tests for differences in medians.. See appendix for variable definitions. 


\subsection{Analysis of share repurchases}

Hribar, Jenkins and Johnson (2006) show that firms use stock repurchases to meet or beat analysts' EPS. They find a disproportionately large number of accretive stock repurchases among firms that would have missed analysts forecast benchmarks without the repurchase. I assess the impact of share repurchases on my earnings string firms to determine whether managers similarly use stock repurchases to manage earnings so as to extend earnings strings.

I examine both the number of shares outstanding (Compustat \#25) and the estimated number of shares repurchased. I measure stock repurchase as the dollar amount of share buyback (Compustat \#115) divided by the average stock price of the year. Panel A of Table 20 shows that most firms in my earnings string sample have more outstanding shares in each year $t-3, t-2$ and $t$ 1 (relative to the earnings break year) than in the previous year. Panel B of Table 20 examines share buyback activity. The trend in share buyback activity is constant. In years $t-3, t-2$ and $t-1$, there are 80.4 percent, 80.3 percent and 79.2 percent of firms respectively who increase their repurchases compared to the previous year.

I also examine the number of earnings string firms that would report an earnings decrease if not for their stock repurchase activity. To do so, I adjust the firm's reported EPS by using the beginning of period's shares outstanding as the denominator and reassess whether the firm will still report an earnings increase with the revised EPS figure. If there is a sufficient reduction in the number of shares outstanding in the fiscal year (which enables firms to report an EPS increase based on the reduced number of shares outstanding), these firms should not be able 
to report an EPS increase when I adjust for the effect of the share buyback activity in the EPS denominator. Panel $\mathrm{C}$ of Table 18 shows that 95 earnings string firms would have reported an EPS decrease in year $t-1$ if not for their share repurchase activity. Excluding these firms from my sample does not change the inferences of my earnings management test results. 
Table 20: Earnings String Firms - Share Repurchases

Panel A: Frequency distribution of shares outstanding

\begin{tabular}{lccc}
\hline Shares outstanding & $\underline{\text { Year t-1 }}$ & $\underline{\text { Year t-2 }}$ & $\underline{\text { Year t-3 }}$ \\
& & & \\
Lower & $16.4 \%$ & $15.6 \%$ & $15.4 \%$ \\
Higher & $83.6 \%$ & $84.5 \%$ & $84.6 \%$ \\
\hline
\end{tabular}

Panel B: Frequency distribution of stock repurchases

\begin{tabular}{|c|c|c|c|}
\hline$\underline{\text { Stock repurchase }}$ & $\underline{\text { Year t-1 }}$ & $\underline{\text { Year t-2}}$ & Year t-3 \\
\hline Lower & $20.8 \%$ & $19.7 \%$ & $19.6 \%$ \\
\hline Higher & $79.2 \%$ & $80.3 \%$ & $80.4 \%$ \\
\hline
\end{tabular}

Panel C: Number of earnings string firms affected by stock repurchase activity

$\underline{\text { Year } \mathrm{t}-1} \quad \underline{\text { Year } \mathrm{t}-2} \quad \underline{\text { Year } \mathrm{t}-3}$

$\begin{array}{llll}\text { Number of firms } & 95 & 92 & 111\end{array}$

\begin{abstract}
Notes to Table 20
Table 20 reports the frequency of changes in shares outstanding and stock repurchase activity of the full sample of earnings string firms. Panel A reports the proportion of earnings string firms that have more/less shares outstanding (Compustat \#25) compared to the previous year. Panel B reports the proportion of earnings string firms that made more/less stock repurchases compared to their previous year's stock repurchase activity. Stock repurchases is measured as the dollar amount of share buyback (Compustat \#115) divided by the average stock price of the year. Panel C reports the number of earnings string firms that would have reported a lower EPS compared to the previous year if not for stock repurchases. The firm's EPS to adjust for the effect of stock repurchase activity is calculated by backing out the denominator (Compustat \#54 x Compustat \#27) in reported EPS and using the beginning of period shares outstanding (Compustat \#25 x Compustat \#27) as the denominator.
\end{abstract}




\subsection{Robustness tests}

In this section, I conduct robustness tests to assess whether the results of my earnings management tests hold using different specifications.

\subsubsection{Control sample}

I first run my earnings management tests using only control firms. Table 21 reports the results of this test. The coefficients of the variables load in the direction as predicted for both the pooled sample regressions and in the Fama-MacBeth regressions. Results are similar using either the modified Jones model discretionary accruals or the performance-adjusted modified Jones model discretionary accruals.

Specifically, the coefficients on LEVERAGE and GROWTH are positive and significant at the 0.01 level for all specifications. The coefficients for LEVERAGE and GROWTH in the pooled regression using discretionary accruals as the dependent variable are 0.059 (t-statistic: 27.79 , $\mathrm{p}<0.001$ ) and 0.051 (t-statistic: 29.53, $\mathrm{p}<0.001$ ) respectively. While I do not have any predictions for SIZE and FIRM AGE, the coefficients for both variables are also positive and coefficient at the 0.01 level for all specifications, except for SIZE in the pooled regression when performanceadjusted discretionary accruals is the dependent variable. The coefficient for SIZE and FIRM AGE in the pooled regression using discretionary accruals as the dependent variable is $0.001(\mathrm{t}-$ statistic: $3.03, \mathrm{p}<0.001$ ) and 0.005 (t-statistic: $9.39, \mathrm{p}<0.001$ ) respectively. 


\section{Table 21: Earnings Management Regressions - Control Sample}

\begin{tabular}{|c|c|c|c|c|c|}
\hline Variables & Pred. sign & Coef. Est & t-statistics & Coef. Est & t-statistics \\
\hline & & $\underline{\text { Model } 1}$ & & $\underline{\text { Model } 2}$ & \\
\hline \multicolumn{6}{|l|}{$\underline{\text { Pooled sample regressions }}$} \\
\hline Intercept & $?$ & -0.045 & $-29.91^{* * *}$ & -0.042 & $-29.72^{* * *}$ \\
\hline SIZE & $?$ & 0.001 & $3.03^{* * *}$ & 0.000 & 1.06 \\
\hline LEVERAGE & + & 0.059 & $27.79^{* * *}$ & 0.060 & $30.73^{* * *}$ \\
\hline GROWTH & + & 0.051 & $29.53^{* * *}$ & 0.043 & $28.08^{* * *}$ \\
\hline FIRM AGE & $?$ & 0.005 & $9.39^{* * *}$ & 0.005 & $9.10^{* * *}$ \\
\hline Number of observations & & 109,297 & & 109,229 & \\
\hline Adj $R^{2}$ & & 0.025 & & 0.023 & \\
\hline \multicolumn{6}{|l|}{ Separate-year regressions } \\
\hline Intercept & $?$ & -0.046 & $-15.51^{* * *}$ & -0.043 & $-15.09^{* * *}$ \\
\hline SIZE & $?$ & 0.002 & $4.23^{* * *}$ & 0.001 & $2.71^{* * *}$ \\
\hline LEVERAGE & + & 0.055 & $13.85^{* * *}$ & 0.060 & $14.89^{* * *}$ \\
\hline GROWTH & + & 0.075 & $12.00^{* * *}$ & 0.056 & $12.04^{* * *}$ \\
\hline FIRM AGE & $?$ & 0.004 & $4.15^{* * *}$ & 0.004 & $5.03^{* * *}$ \\
\hline Number of years & & 49 & & 49 & \\
\hline Mean adj. $R^{2}$ & & 0.024 & & 0.023 & \\
\hline
\end{tabular}

\section{Notes to Table 21}

Table 21 reports the results of both pooled and Fama-MacBeth regressions for the benchmark sample of non-earnings string firm-year observations between 1951-2006. Model 1 uses the modified Jones model discretionary accruals as the dependent variable. Model 2 adjusts for accounting performance by using the performance adjusted discretionary accruals following Kothari, Leone and Wasley (2005). t-statistics for the pooled regressions are calculated using Newey-West standard errors corrected for autocorrelation. t-statistics for the Fama-MacBeth regressions are calculated using the standard error of the mean coefficient estimates across years. ${ }^{* * *} / * * / *$ denotes significance levels at the $1 \%, 5 \%$ and $10 \%$ level (two-tailed) respectively. See appendix for variable definitions. 


\subsubsection{Benchmark firms with annual earnings increases}

I next test whether my earnings management results hold when I restrict my benchmark sample to non-earnings string firm-year observations that report an earnings increase. All firms in my earnings string samples report an annual earnings increase, by construction, but not all firms in the Compustat population report an earnings increase. To allow for greater comparability, I restrict my benchmark sample to non-earnings string firm-year observations that report an earnings increase and rerun my earnings management regression (equation 1). The main results obtained in Table 6 might be biased upwards if firms in the benchmark sample that do not report annual earnings increases have abnormally low discretionary accruals. However, the remaining firms in the benchmark sample might also be biased toward income-increasing earnings management if the non-earnings string firms in the Compustat population rely on income-increasing earnings management to report annual earnings increases.

Table 22 reports the results of this alternative specification. The inferences with respect to PREBREAK1 are similar to those in Table 6. Specifically, the coefficient for PREBREAK1 is 0.021 (t-statistic: 11.96, $\mathrm{p}<0.001$ ), 0.018 (t-statistic: 8.77, $\mathrm{p}<0.001$ ) and 0.012 (t-statistic: $4.84, \mathrm{p}<0.001$ ) for the first, second and third earnings string samples respectively based on pooled regression results using discretionary accruals as the dependent variable. The Fama-MacBeth regressions yield similar results - the coefficient for PREBREAK1 is 0.019 (t-statistic: 7.69, p<0.001), 0.014 (tstatistic: $6.03, \mathrm{p}<0.001$ ) and 0.013 (t-statistic: $3.80, \mathrm{p}<0.001$ ) for the first, second and third earnings string samples respectively. 
I obtain similar results when I use performance-adjusted discretionary accruals (model 2), although the coefficient estimates are lower than those based on unadjusted discretionary accruals. This is expected since the discretionary accruals are adjusted for changes in accounting performance. Specifically, the pooled regressions with performance adjusted discretionary accruals as the dependent variable show coefficients for PREBREAK1 of 0.015 (t-statistic: 9.15, $\mathrm{p}<0.001$ ), 0.013 (t-statistic: 6.56, $\mathrm{p}<0.001$ ) and 0.009 (t-statistic: 3.71, $\mathrm{p}<0.001$ ) for the first, second and third earnings string samples respectively. I also obtain similar results when I run separateyear Fama MacBeth regressions instead of a single pooled regression with performance adjusted discretionary accruals as the dependent variable. I find statistically significant (at the 0.01 level) evidence of income-increasing earnings management in the year preceding the earnings break across all three earnings string samples.

Table 22 also shows that there is a positive coefficient for PREBREAK2 for the first earnings string sample but not for the second or third earnings string samples. However, while the PREBREAK2 coefficients in the first earnings string sample are positive and significant across all specifications, the magnitudes are lower than those shown in Table 6. Specifically, the coefficient for PREBREAK2 is 0.6 percent ( 0.3 percent) using discretionary accruals (performance adjusted discretionary accruals) as the dependent variable, significant at the $0.01(0.10)$ level for the pooled regressions, and 0.4 percent $(0.3$ percent), significant at the $0.01(0.10)$ level for the Fama-MacBeth regressions. Finally, unlike the results in Table 6, the coefficient for BEGSTRING in the first earnings string sample is no longer positive and significant. 
Table 22: Earnings Management Regressions - Firms with Earnings Increases

\begin{tabular}{|c|c|c|c|c|c|}
\hline Variables & Pred. sign & Coef. Est & t-statistics & Coef. Est & t-statistics \\
\hline & & Model 1 & & Model 2 & \\
\hline \multicolumn{6}{|l|}{$\underline{\text { Pooled sample regressions }}$} \\
\hline PREBREAK1 & + & 0.021 & $11.96^{* * *}$ & 0.015 & $9.15^{* * *}$ \\
\hline PREBREAK2 & + & 0.006 & $3.19^{* * *}$ & 0.003 & $1.65^{*}$ \\
\hline PREBREAK3 & $?$ & -0.001 & -0.42 & -0.002 & -1.25 \\
\hline BEGSTRING & $?$ & 0.002 & 1.37 & -0.002 & -1.18 \\
\hline SIZE & $?$ & 0.000 & 0.57 & -0.001 & $-2.72^{* * *}$ \\
\hline LEVERAGE & + & 0.067 & $24.99^{* * *}$ & 0.071 & $28.72^{* * *}$ \\
\hline GROWTH & + & 0.053 & $25.58^{* * *}$ & 0.044 & $23.53^{* * *}$ \\
\hline FIRM AGE & $?$ & 0.003 & $4.21^{* * *}$ & 0.002 & $3.73^{* * *}$ \\
\hline Number of observations & & 72,825 & & 72,824 & \\
\hline Adj $R^{2}$ & & 0.032 & & 0.029 & \\
\hline \multicolumn{6}{|l|}{ Separate-year regressions } \\
\hline PREBREAK1 & + & 0.019 & $7.69^{* * *}$ & 0.015 & $5.53^{* * *}$ \\
\hline PREBREAK2 & + & 0.004 & $2.49^{* * *}$ & 0.003 & $1.75^{*}$ \\
\hline PREBREAK3 & $?$ & -0.002 & -1.29 & -0.003 & -1.72 \\
\hline BEGSTRING & $?$ & 0.001 & 0.54 & -0.002 & -1.37 \\
\hline SIZE & $?$ & 0.001 & 0.68 & 0.001 & 0.24 \\
\hline LEVERAGE & + & 0.063 & $13.14^{* * *}$ & 0.070 & $12.74^{* * *}$ \\
\hline GROWTH & + & 0.063 & $11.19^{* * *}$ & 0.045 & $11.10^{* * *}$ \\
\hline FIRM AGE & $?$ & 0.002 & $2.18^{* *}$ & 0.002 & $2.62^{* *}$ \\
\hline Number of years & & 48 & & 48 & \\
\hline Mean adj. $\mathrm{R}^{2}$ & & 0.032 & & 0.029 & \\
\hline
\end{tabular}


Table 22 (Continued)

Panel B: Second earnings string sample

\begin{tabular}{|c|c|c|c|c|c|}
\hline Variables & Pred. sign & Coef. Est & t-statistics & Coef. Est & t-statistics \\
\hline & & Model 1 & & Model 2 & \\
\hline \multicolumn{6}{|l|}{$\underline{\text { Pooled sample regressions }}$} \\
\hline PREBREAK1 & + & 0.018 & $8.77^{* * *}$ & 0.013 & $6.56^{* * *}$ \\
\hline PREBREAK2 & + & 0.003 & 1.50 & -0.001 & -0.49 \\
\hline PREBREAK3 & $?$ & -0.003 & -1.41 & -0.004 & $-2.00^{* *}$ \\
\hline BEGSTRING & $?$ & -0.003 & $-1.84^{*}$ & -0.005 & $-3.69^{* * *}$ \\
\hline SIZE & $?$ & 0.000 & 0.84 & -0.001 & $-2.33^{* * *}$ \\
\hline LEVERAGE & + & 0.065 & $22.49^{* * *}$ & 0.069 & $25.92^{* * *}$ \\
\hline GROWTH & + & 0.051 & $22.10^{* * *}$ & 0.042 & $20.26^{* * *}$ \\
\hline FIRM AGE & $?$ & 0.003 & $3.37^{* * *}$ & 0.002 & $3.23^{* * *}$ \\
\hline Number of observations & & 61,362 & & 61,329 & \\
\hline Adj $R^{2}$ & & 0.028 & & 0.026 & \\
\hline \multicolumn{6}{|l|}{ Separate-year regressions } \\
\hline PREBREAK1 & + & 0.014 & $6.03^{* * *}$ & 0.010 & $4.61^{* * *}$ \\
\hline PREBREAK2 & + & 0.004 & $1.69^{*}$ & 0.001 & 0.50 \\
\hline PREBREAK3 & $?$ & -0.001 & -0.53 & -0.002 & -0.85 \\
\hline BEGSTRING & $?$ & -0.002 & -0.91 & -0.004 & $-2.19 * *$ \\
\hline SIZE & $?$ & 0.001 & 1.44 & -0.000 & -0.75 \\
\hline LEVERAGE & + & 0.067 & $12.34^{* * *}$ & 0.075 & $13.33^{* * *}$ \\
\hline GROWTH & + & 0.060 & $9.04^{* * *}$ & 0.041 & $7.25^{* * *}$ \\
\hline FIRM AGE & $?$ & 0.002 & 1.55 & 0.002 & $2.01^{* *}$ \\
\hline Number of years & & 45 & & 45 & \\
\hline Mean adj. $R^{2}$ & & 0.028 & & 0.026 & \\
\hline
\end{tabular}




\section{Table 22 (Continued)}

Panel C: Third earnings string sample

\begin{tabular}{|c|c|c|c|c|c|}
\hline Variables & Pred. sign & Coef. Est & t-statistics & Coef. Est & t-statistics \\
\hline & & Model 1 & & Model 2 & \\
\hline \multicolumn{6}{|l|}{ Pooled sample regressions } \\
\hline PREBREAK1 & + & 0.012 & $4.84^{* * *}$ & 0.009 & $3.71^{* * *}$ \\
\hline PREBREAK2 & + & 0.000 & 0.12 & -0.001 & -0.56 \\
\hline PREBREAK3 & $?$ & -0.002 & -0.85 & -0.002 & -0.96 \\
\hline BEGSTRING & $?$ & -0.002 & -1.00 & -0.003 & -1.45 \\
\hline SIZE & $?$ & 0.000 & 1.08 & -0.000 & $-1.92^{*}$ \\
\hline LEVERAGE & + & 0.062 & $20.41^{* * *}$ & 0.066 & $23.33^{* * *}$ \\
\hline GROWTH & + & 0.050 & $21.10^{* * *}$ & 0.041 & $19.47^{* * *}$ \\
\hline FIRM AGE & $?$ & 0.002 & $2.85^{* * *}$ & 0.002 & $2.78^{* * *}$ \\
\hline Number of observations & & 55,498 & & 55,466 & \\
\hline Adj $R^{2}$ & & 0.026 & & 0.024 & \\
\hline \multicolumn{6}{|l|}{ Separate-year regressions } \\
\hline PREBREAK1 & + & 0.016 & $4.54^{* * *}$ & 0.013 & $3.80^{* * *}$ \\
\hline PREBREAK2 & + & 0.002 & 0.58 & 0.001 & 0.19 \\
\hline PREBREAK3 & $?$ & 0.002 & 0.63 & 0.002 & 0.81 \\
\hline BEGSTRING & $?$ & 0.001 & 0.35 & 0.000 & 0.06 \\
\hline SIZE & $?$ & 0.001 & $2.27^{* *}$ & 0.000 & 0.27 \\
\hline LEVERAGE & + & 0.068 & $11.57^{* * *}$ & 0.076 & $13.00^{* * *}$ \\
\hline GROWTH & + & 0.061 & $8.22^{* * *}$ & 0.041 & $6.39^{* * *}$ \\
\hline FIRM AGE & $?$ & 0.001 & 1.04 & 0.002 & 1.55 \\
\hline Number of years & & 43 & & 43 & \\
\hline Mean adj. $\mathrm{R}^{2}$ & & 0.026 & & 0.024 & \\
\hline
\end{tabular}

\section{Notes to Table 22}

Table 22 reports the results of both pooled and Fama-MacBeth regressions of the earnings management tests. Model 1 uses the modified Jones model discretionary accruals as the dependent variable. Model 2 uses the performance-adjusted modified Jones model discretionary accruals as the dependent variable. $t$ statistics for the pooled regressions are calculated using Newey-West standard errors corrected for autocorrelation and heteroskedasticity. t-statistics for the Fama-MacBeth regressions are calculated using the standard error of the mean coefficient estimates across years. The sample period for the regression tests spans 1952-2005. The first/second/third string sample comprises 6,130/2,540/1,132 earnings string firms as described in Table 1. The benchmark sample is consisted of all Compustat firm-year observations between 1951-2006 that report an annual EPS increase (excluding banks and utilities and the earnings string sample). ${ }^{* *} / * * *$ denotes significance levels at the $1 \%, 5 \%$ and $10 \%$ level (two-tailed) respectively. See appendix for variable definitions. 


\subsubsection{Within firm comparison}

I implement a within-firm comparison to examine whether earnings string firms engage in income-increasing earnings management in the last two years preceding the break in the earnings string patterns compared with their post-break periods and before the inception of their earnings string periods. This sensitivity test is intended to assess whether earnings string firms manage earnings upwards more in the last two years of their earnings string periods compared with other times.

To implement this test, I rerun equation (1) using as the benchmark samples the nonearnings string firm-year observations of the firms in my earnings string samples. I also drop non-earnings string firm-year observations with an earnings decrease to reduce the impact of poor performance. My inferences are not affected by this choice. As with the earnings management tests reported in Table 6, my first/second/third earnings string sample is composed of 6,130, 2,540 and 1,132 earnings string firms respectively.

Table 23 reports the results of the within-firm comparison. I find evidence of incomeincreasing earnings management in the last year of the earnings string period across all specifications, significant at the 0.01 level. I also find that discretionary accruals in year $t-2$ for all three earnings string samples are consistently higher than their benchmark time periods, significant at the 0.05 (or better) level. Results are similar when I use performance adjusted discretionary accruals as my earnings management measure. Finally, I do not find evidence of income-increasing earnings management for PREBREAK3 and BEGSTRING. The results suggest 
that the income-increasing earnings management behavior of earnings string firms in the last two years in the earnings string period is statistically different from their earnings management behavior when the same firms are out of their earnings string periods. Overall, I interpret the results in this test as providing additional support for my prediction in hypothesis 1. 
Table 23: Earnings Management Regressions - Within Firm Comparison

\begin{tabular}{|c|c|c|c|c|c|}
\hline Variables & Pred. sign & Coef. Est & t-statistics & Coef. Est & t-statistics \\
\hline & & $\underline{\text { Model } 1}$ & & $\underline{\text { Model } 2}$ & \\
\hline \multicolumn{6}{|l|}{$\underline{\text { Pooled sample regressions }}$} \\
\hline PREBREAK1 & + & 0.021 & $16.92^{* * *}$ & 0.016 & $13.74^{* * *}$ \\
\hline PREBREAK2 & + & 0.006 & $5.03^{* * *}$ & 0.004 & $3.05^{* * *}$ \\
\hline PREBREAK3 & $?$ & -0.001 & -0.85 & -0.002 & -1.32 \\
\hline BEGSTRING & $?$ & 0.001 & 0.55 & -0.001 & -1.03 \\
\hline SIZE & $?$ & 0.000 & 1.30 & -0.000 & -1.57 \\
\hline LEVERAGE & + & 0.070 & $25.34^{* * *}$ & 0.078 & $30.45^{* * *}$ \\
\hline GROWTH & + & 0.040 & $17.10^{* * *}$ & 0.036 & $16.93^{* * *}$ \\
\hline FIRM AGE & $?$ & -0.000 & -0.48 & 0.000 & 0.45 \\
\hline Number of observations & & 70,861 & & 68,242 & \\
\hline Adj $R^{2}$ & & 0.032 & & 0.033 & \\
\hline \multicolumn{6}{|l|}{$\underline{\text { Separate-year regressions }}$} \\
\hline PREBREAK1 & + & 0.021 & $8.67^{* * *}$ & 0.016 & $6.28^{* * *}$ \\
\hline PREBREAK2 & + & 0.006 & $5.68^{* * *}$ & 0.004 & $3.30^{* * *}$ \\
\hline PREBREAK3 & $?$ & -0.005 & $-1.87^{*}$ & -0.004 & $2.22^{* *}$ \\
\hline BEGSTRING & $?$ & 0.000 & 0.24 & -0.001 & -1.01 \\
\hline SIZE & $?$ & -0.002 & -0.89 & -0.002 & -1.34 \\
\hline LEVERAGE & + & 0.071 & $6.09^{* * *}$ & 0.082 & $6.91^{* * *}$ \\
\hline GROWTH & + & 0.046 & $9.14^{* * *}$ & 0.037 & $8.92^{* * *}$ \\
\hline FIRM AGE & $?$ & -0.000 & -0.19 & 0.001 & 1.33 \\
\hline Number of years & & 49 & & 49 & \\
\hline Mean adj. $\mathrm{R}^{2}$ & & 0.030 & & 0.025 & \\
\hline
\end{tabular}


Table 23 (Continued)

Panel B: Second earnings string sample

\begin{tabular}{|c|c|c|c|c|c|}
\hline Variables & Pred. sign & Coef. Est & t-statistics & Coef. Est & t-statistics \\
\hline & & $\underline{\text { Model } 1}$ & & $\underline{\text { Model } 2}$ & \\
\hline \multicolumn{6}{|l|}{$\underline{\text { Pooled sample regressions }}$} \\
\hline PREBREAK1 & + & 0.020 & $14.40^{* * *}$ & 0.015 & $11.15^{* * *}$ \\
\hline PREBREAK2 & + & 0.005 & $3.40^{* * *}$ & 0.002 & 1.20 \\
\hline PREBREAK3 & $?$ & -0.002 & -1.57 & -0.003 & $-1.85^{*}$ \\
\hline BEGSTRING & $?$ & 0.001 & 0.53 & -0.002 & -1.48 \\
\hline SIZE & $?$ & -0.000 & -0.89 & -0.001 & $-2.95^{* *}$ \\
\hline LEVERAGE & + & 0.074 & $21.43^{* * *}$ & 0.086 & $26.43^{* * *}$ \\
\hline GROWTH & + & 0.044 & $12.75^{* * *}$ & 0.040 & $13.60^{* * *}$ \\
\hline FIRM AGE & $?$ & 0.000 & 0.40 & 0.002 & $1.89^{*}$ \\
\hline Number of observations & & 42,727 & & 41,799 & \\
\hline Adj $R^{2}$ & & 0.037 & & 0.040 & \\
\hline \multicolumn{6}{|l|}{ Separate-year regressions } \\
\hline PREBREAK1 & + & 0.020 & $8.08^{* * *}$ & 0.015 & $5.71^{* * *}$ \\
\hline PREBREAK2 & + & 0.005 & $3.89^{* * *}$ & 0.002 & 1.57 \\
\hline PREBREAK3 & $?$ & -0.004 & $-1.87^{*}$ & -0.004 & $-1.98^{*}$ \\
\hline BEGSTRING & $?$ & 0.001 & 0.70 & -0.001 & -0.80 \\
\hline SIZE & $?$ & -0.002 & -0.95 & -0.001 & -1.56 \\
\hline LEVERAGE & + & 0.074 & $6.25^{* * *}$ & 0.086 & $7.14^{* * *}$ \\
\hline GROWTH & + & 0.048 & $8.87^{* * *}$ & 0.040 & $9.61^{* * *}$ \\
\hline FIRM AGE & $?$ & 0.001 & 0.86 & 0.003 & $2.43^{* *}$ \\
\hline Number of years & & 49 & & 49 & \\
\hline Mean adj. $R^{2}$ & & 0.036 & & 0.040 & \\
\hline
\end{tabular}




\section{Table 23 (Continued)}

Panel C: Third earnings string sample

\begin{tabular}{|c|c|c|c|c|c|}
\hline Variables & Pred. sign & Coef. Est & t-statistics & Coef. Est & t-statistics \\
\hline & & Model 1 & & Model 2 & \\
\hline \multicolumn{6}{|l|}{$\underline{\text { Pooled sample regressions }}$} \\
\hline PREBREAK1 & + & 0.018 & $10.30^{* * *}$ & 0.014 & $8.38^{* * *}$ \\
\hline PREBREAK2 & + & 0.004 & $2.17^{* *}$ & 0.002 & 0.97 \\
\hline PREBREAK3 & ? & -0.001 & -0.62 & -0.001 & -0.41 \\
\hline BEGSTRING & ? & -0.000 & -0.16 & -0.002 & -1.20 \\
\hline SIZE & ? & -0.001 & $-2.28^{* *}$ & -0.001 & $-4.04^{* * *}$ \\
\hline LEVERAGE & + & 0.075 & $16.77^{* * *}$ & 0.088 & $20.80^{* * *}$ \\
\hline GROWTH & + & 0.046 & $10.25^{* * *}$ & 0.040 & $10.21^{* * *}$ \\
\hline FIRM AGE & ? & 0.000 & 0.12 & 0.003 & $2.24^{* *}$ \\
\hline Number of observations & & 23,896 & & 23,565 & \\
\hline Adj $R^{2}$ & & 0.038 & & 0.041 & \\
\hline \multicolumn{6}{|l|}{ Separate-year regressions } \\
\hline PREBREAK1 & + & 0.018 & $7.11^{* * *}$ & 0.014 & $5.10^{* * *}$ \\
\hline PREBREAK2 & + & 0.004 & $2.55^{* *}$ & 0.001 & 0.64 \\
\hline PREBREAK3 & $?$ & -0.002 & -0.69 & -0.002 & 1.04 \\
\hline BEGSTRING & ? & 0.002 & 1.46 & -0.001 & -0.36 \\
\hline SIZE & $?$ & -0.003 & -1.34 & -0.002 & $-2.22^{* *}$ \\
\hline LEVERAGE & + & 0.076 & $6.26^{* * *}$ & 0.088 & $6.97^{* * *}$ \\
\hline GROWTH & + & 0.049 & $8.09^{* * *}$ & 0.040 & $7.82^{* * *}$ \\
\hline FIRM AGE & $?$ & 0.001 & 0.63 & 0.004 & $2.19^{* *}$ \\
\hline Number of years & & 49 & & 49 & \\
\hline Mean adj. $\mathrm{R}^{2}$ & & 0.036 & & 0.041 & \\
\hline
\end{tabular}

\section{Notes to Table 23}

Table 23 reports the results of both pooled and Fama-MacBeth regressions of the earnings management tests. Model 1 uses the modified Jones model discretionary accruals as the dependent variable. Model 2 uses the performance-adjusted modified Jones model discretionary accruals as the dependent variable. $t$ statistics for the pooled regressions are calculated using Newey-West standard errors corrected for autocorrelation and heteroskedasticity. t-statistics for the Fama-MacBeth regressions are calculated using the standard error of the mean coefficient estimates across years. The sample period for the regression tests spans 1952-2005. The first/second/third string sample comprises 6,130/2,540/1,132 earnings string firms as described in Table 1. The benchmark samples are taken from the non-earnings string periods of the earnings string firms. Only firm-year observations that report an annual earnings increase are used. $* * * / * /^{*}$ denotes significance levels at the $1 \%, 5 \%$ and $10 \%$ level (two-tailed) respectively. See appendix for variable definitions. 


\subsubsection{Long earnings string firms}

I assess whether the results of my earnings management tests are affected by the definition of an earnings string. Forty percent of my sample firms across all my earnings string samples report exactly three consecutive years of annual earnings increases and 25 percent report exactly four consecutive years of annual earnings increases. I assess whether my earnings management results hold when I use firms with earnings strings that exceed three or four consecutive years of annual earnings increases. Specifically, I rerun the same regressions as those reported in Table 6 excluding earnings string firms that have exactly three or four consecutive years of annual earnings increases.

Panel A (B) of Table 24 reports the results of the earnings management tests for firms with four (five) or more consecutive years of annual earnings increases. Results show consistent evidence that PREBREAK1 is positive and significant at the 0.01 level. The coefficient estimates for PREBREAK1 are also higher compared with the regression results in Table 6. Specifically, discretionary accruals in the last year of the earnings string period is 2.3 percent of total assets ( $t$ statistic: $11.38, \mathrm{p}<0.001), 2.1$ percent (t-statistic: $8.17, \mathrm{p}<0.001)$ and 1.6 percent (t-statistic: 5.01 , $\mathrm{p}<0.001$ ) for earnings string firms with four or more consecutive years of annual earnings increases, and 2.7 percent (t-statistic: 10.93, $\mathrm{p}<0.001), 2.6$ percent (t-statistic: $8.20, \mathrm{p}<0.001)$ and 1.4 percent (t-statistic: $3.48, \mathrm{p}<0.001)$ for earnings string firms with five or more consecutive years of annual earnings increases. 
As before, I obtain mixed evidence of income-increasing earnings management in year $t$ 2. While the coefficients for PREBREAK2 are positive across all specifications, the statistical significance varies. Specifically, the coefficient estimates for PREBREAK2 are significant (at the 0.01 level) for the first and second earnings string samples (using either four years or five years as the threshold in defining an earnings string) when I use discretionary accruals as the dependent variable, but not for the third earnings string sample. The coefficient estimates for PREBREAK2 are significant (at the 0.01 level) only for the first earnings string sample when I use performance adjusted discretionary accruals as the dependent variable.

There are two noticeable differences in these regression tests compared with the regressions reported in Table 6. First, the coefficient estimates for PREBREAK3 are positive across all three earnings string samples, although they are small (consistently less than 1 percent of total assets). I interpret this result to suggest that there might be income-increasing earnings management as far back as three years before the break in the earnings string patterns for firms with earnings strings of five or more years of consecutive annual earnings increases, with the amount of earnings management increasing toward the last year of the earnings string period.

Second, firms with five or more consecutive years of annual earnings increases (i.e., the first earnings string sample) appear to be systematically engaging in income-increasing earnings management throughout their earnings string periods based on earnings management tests that use discretionary accruals as the dependent variable. The coefficient estimates for PREBREAK1, PREBREAK2, PREBREAK3 and BEGSTRING are 0.027, 0.014, 0.008 and 0.005 respectively, all 
significant at the 0.01 level. After controlling for performance, however, the regression results show evidence of income-increasing earnings management for the first earnings string sample only during the last two years of the earnings string periods. Specifically, the performance adjusted discretionary accruals are 1.8 percent (t-statistic: $7.88, \mathrm{p}<0.001)$ and 0.8 percent $(\mathrm{t}-$ statistic: $3.03, p<0.001$ ) in the last and second last years of the earnings string period respectively and insignificant at the 0.10 level for PREBREAK3 and BEGSTRING. I interpret these results as suggesting the importance of controlling for the effect of performance in earnings management tests. 
Table 24: Earnings Management Regressions - Long Earnings String Firms

\begin{tabular}{|c|c|c|c|c|c|}
\hline Variables & Pred. sign & Coef. Est & t-statistics & Coef. Est & t-statistics \\
\hline & & $\underline{\text { Model } 1}$ & & $\underline{\text { Model } 2}$ & \\
\hline \multicolumn{6}{|l|}{$\underline{\text { String }=4 \text { years and longer }}$} \\
\hline PREBREAK1 & + & 0.023 & $11.38^{* * *}$ & 0.017 & $8.51^{* * *}$ \\
\hline PREBREAK2 & + & 0.012 & $5.42^{* * *}$ & 0.007 & $3.50^{* * *}$ \\
\hline PREBREAK3 & $?$ & 0.007 & $3.28^{* * *}$ & 0.003 & 1.53 \\
\hline BEGSTRING & $?$ & 0.002 & 1.34 & -0.002 & -1.23 \\
\hline SIZE & $?$ & 0.000 & 0.30 & -0.001 & -3.00 \\
\hline LEVERAGE & + & 0.066 & $23.39^{* * *}$ & 0.070 & $27.01^{* * *}$ \\
\hline GROWTH & + & 0.052 & $23.94^{* * *}$ & 0.043 & $22.00^{* * *}$ \\
\hline FIRM AGE & $?$ & 0.003 & $3.83^{* * *}$ & 0.002 & $3.42^{* * *}$ \\
\hline Number of observations & & 66,200 & & 66,160 & \\
\hline Adj $R^{2}$ & & 0.031 & & 0.028 & \\
\hline \multicolumn{6}{|l|}{$\underline{\text { String }=5 \text { years and longer }}$} \\
\hline PREBREAK1 & + & 0.027 & $10.93^{* * *}$ & 0.018 & $7.88^{* * *}$ \\
\hline PREBREAK2 & + & 0.014 & $5.29^{* * *}$ & 0.008 & $3.03^{* * *}$ \\
\hline PREBREAK3 & $?$ & 0.008 & $2.95^{* * *}$ & 0.002 & 0.90 \\
\hline BEGSTRING & $?$ & 0.005 & $3.20^{* * *}$ & 0.000 & 0.01 \\
\hline SIZE & $?$ & 0.000 & 0.12 & -0.001 & $-2.97^{* * *}$ \\
\hline LEVERAGE & + & 0.065 & $22.38^{* * *}$ & 0.069 & $25.81^{* * *}$ \\
\hline GROWTH & + & 0.051 & $22.57^{* * *}$ & 0.042 & $20.71^{* * *}$ \\
\hline FIRM AGE & $?$ & 0.003 & $3.99^{* * *}$ & 0.003 & $3.64^{* * *}$ \\
\hline Number of observations & & 61,344 & & 61,308 & \\
\hline Adj $R^{2}$ & & 0.030 & & 0.026 & \\
\hline
\end{tabular}


Table 24 (Continued)

Panel B: Second earnings string sample

\begin{tabular}{|c|c|c|c|c|c|}
\hline Variables & Pred. sign & Coef. Est & t-statistics & Coef. Est & t-statistics \\
\hline & & Model 1 & & Model 2 & \\
\hline \multicolumn{6}{|l|}{ String $=4$ years and longer } \\
\hline PREBREAK1 & + & 0.021 & $8.17^{* * *}$ & 0.015 & $6.28^{* * *}$ \\
\hline PREBREAK2 & + & 0.006 & $2.63^{* * *}$ & 0.001 & 0.23 \\
\hline PREBREAK3 & $?$ & 0.004 & 1.50 & 0.001 & 0.57 \\
\hline BEGSTRING & $?$ & -0.003 & -1.83 & -0.005 & $-3.68^{* * *}$ \\
\hline SIZE & $?$ & 0.000 & 1.09 & -0.000 & $-2.06^{* *}$ \\
\hline LEVERAGE & + & 0.063 & $21.32^{* * *}$ & 0.067 & $24.56^{* * *}$ \\
\hline GROWTH & + & 0.051 & $21.58^{* * *}$ & 0.042 & $19.85^{* * *}$ \\
\hline FIRM AGE & $?$ & 0.002 & $3.01^{* * *}$ & 0.002 & $2.94^{* * *}$ \\
\hline Number of observations & & 58,237 & & 58,205 & \\
\hline Adj $R^{2}$ & & 0.028 & & 0.025 & \\
\hline \multicolumn{6}{|l|}{$\underline{\text { String }=5 \text { years and longer }}$} \\
\hline PREBREAK1 & + & 0.026 & $8.20^{* * *}$ & 0.019 & $6.35^{* * *}$ \\
\hline PREBREAK2 & + & 0.009 & $3.00^{* * *}$ & 0.001 & 0.50 \\
\hline PREBREAK3 & $?$ & 0.009 & $3.03^{* * *}$ & 0.006 & $1.99^{* *}$ \\
\hline BEGSTRING & $?$ & -0.001 & -0.86 & -0.005 & $-3.06^{* * *}$ \\
\hline SIZE & $?$ & 0.000 & 1.05 & -0.000 & $-2.00^{* * *}$ \\
\hline LEVERAGE & + & 0.062 & $20.54^{* * *}$ & 0.066 & $23.57^{* * *}$ \\
\hline GROWTH & + & 0.050 & $21.22^{* * *}$ & 0.042 & $19.52^{* * *}$ \\
\hline FIRM AGE & $?$ & 0.002 & $2.81^{* * *}$ & 0.002 & $2.74^{* * *}$ \\
\hline Number of observations & & 55,887 & & 55,855 & \\
\hline Adj $R^{2}$ & & 0.027 & & 0.025 & \\
\hline
\end{tabular}




\section{Table 24 (Continued)}

Panel C: Third earnings string sample

\begin{tabular}{|c|c|c|c|c|c|}
\hline Variables & Pred. sign & Coef. Est & t-statistics & Coef. Est & t-statistics \\
\hline & & Model 1 & & Model 2 & \\
\hline \multicolumn{6}{|l|}{$\underline{\text { String }=4 \text { years and longer }}$} \\
\hline PREBREAK1 & + & 0.016 & $5.01^{* * *}$ & 0.012 & $3.73^{* * *}$ \\
\hline PREBREAK2 & + & 0.004 & 1.07 & 0.001 & 0.21 \\
\hline PREBREAK3 & $?$ & 0.005 & 1.48 & 0.003 & 0.99 \\
\hline BEGSTRING & $?$ & -0.002 & -0.97 & -0.003 & -1.42 \\
\hline SIZE & $?$ & 0.000 & 1.20 & -0.000 & $-1.76^{*}$ \\
\hline LEVERAGE & + & 0.062 & $20.16^{* * *}$ & 0.066 & $23.02^{* * *}$ \\
\hline GROWTH & + & 0.050 & $20.98^{* * *}$ & 0.041 & $19.37^{* * *}$ \\
\hline FIRM AGE & $?$ & 0.002 & $2.67^{* * *}$ & 0.002 & $2.61^{* * *}$ \\
\hline Number of observations & & 54,028 & & 53,996 & \\
\hline Adj $R^{2}$ & & 0.027 & & 0.024 & \\
\hline \multicolumn{6}{|l|}{$\underline{\text { String }=5 \text { years and longer }}$} \\
\hline PREBREAK1 & + & 0.014 & $3.48^{* * *}$ & 0.010 & $2.48^{* *}$ \\
\hline PREBREAK2 & + & 0.004 & 0.98 & 0.002 & 0.43 \\
\hline PREBREAK3 & $?$ & 0.010 & $2.23^{* *}$ & 0.008 & $1.87^{*}$ \\
\hline BEGSTRING & $?$ & 0.000 & 0.10 & -0.001 & -0.32 \\
\hline SIZE & $?$ & 0.000 & 1.37 & -0.000 & -1.61 \\
\hline LEVERAGE & + & 0.062 & $19.84^{* * *}$ & 0.065 & $22.63^{* * *}$ \\
\hline GROWTH & + & 0.050 & $20.88^{* * *}$ & 0.041 & $19.27^{* * *}$ \\
\hline FIRM AGE & $?$ & 0.002 & $2.55^{* * *}$ & 0.002 & $2.50^{* * *}$ \\
\hline Number of observations & & 52,850 & & 52,818 & \\
\hline Adj $R^{2}$ & & 0.026 & & 0.024 & \\
\hline
\end{tabular}

Notes to Table 24

Table 24 reports the results of both pooled and Fama-MacBeth regressions of the earnings management tests. Model 1 uses the modified Jones model discretionary accruals as the dependent variable. Model 2 uses the performance-adjusted modified Jones model discretionary accruals as the dependent variable. $t$ statistics for the pooled regressions are calculated using Newey-West standard errors corrected for autocorrelation and heteroskedasticity. t-statistics for the Fama-MacBeth regressions are calculated using the standard error of the mean coefficient estimates across years. The sample period for the regression tests spans 1952-2005. There are 3,613/1,455/636 earnings string firms with at least four consecutive years of annual EPS increases, and 2,095/828/337 earnings string firms with at least five consecutive years of annual EPS increases in the first/second/third string sample respectively. The benchmark sample is consisted of all Compustat firm-year observations between 1951-2006 that report an annual EPS increase (excluding banks and utilities and the earnings string sample). ${ }^{* * * * * *}$ denotes significance levels at the $1 \%, 5 \%$ and $10 \%$ level (two-tailed) respectively. See appendix for variable definitions. 


\subsubsection{Other sensitivity tests}

Two alternative methods to correct for correlation in the residuals across observations for the same firm in different years are the use of clustered standard errors and the use of a fixed effects regression model. I rerun the tests reported in Table 6 using both approaches to test the robustness of my results. I first cluster my sample by firms to obtain Rogers clustered standard errors. Inferences are not qualitatively affected by using this specification. That is, I find evidence of income-increasing earnings management (significant at the 0.01 level) in the last year of the earnings string periods across all earnings string samples, and evidence of income-increasing earnings management (significant at the 0.01 level) in the second last year of the earnings string periods (results not tabulated). I do not find evidence of income-increasing earnings management in PREBREAK3 and BEGSTRING, except for PREBREAK3 (coefficient estimate: 0.003, t-statistic: 1.86) in the first earnings string sample using performance adjusted discretionary accruals as the dependent variable (significant at the 0.10 level) and BEGSTRING (coefficient estimate: 0.004, $\mathrm{t}$ statistic: 2.11) in the first earnings string sample using discretionary accruals as the dependent variable (significant at the 0.05 level).

Next, I run a fixed effects model by including dummy variables for each firm and each

year. My results are also robust to this econometric specification. The results (not tabulated) show consistent evidence of income-increasing earnings management (significant at the 0.01 level) in the last year of the earnings string periods across all earnings string samples. The results also show evidence of income-increasing earnings management (significant at the 0.01 level) for the 
first earnings string sample in the second last year of the earnings string period, but not for the second and third earnings string samples. The coefficient estimates for PREBREAK3 and BEGSTRING are insignificant across all specifications.

Finally, prior research suggests that earnings management behaviors differ between firms reporting losses and firms reporting profits (Degeorge et al. 1999). Specifically, managers of loss firms exhibit less tendency to reduce losses than managers of profit firms to report an earnings increase. I repeat my earnings management tests in Table 6 excluding earnings string firms that report losses. 1,591 earnings strings out of the full sample of 10,562 earnings strings report at least one year of negative annual EPS during their earnings strings. Most of the loss firms are in the first earnings string sample (1,123 firms). After removing loss firms from my earnings string samples and repeating the earnings management tests in Table 6, I find stronger evidence of income-increasing earnings management in the last year of the earnings string period across all earnings string samples (results not tabulated). Specifically, the coefficients for PREBREAK1 are 0.029, 0.020 and 0.011 respectively for the first, second and third earnings string samples, significant at the 0.01 level. There is evidence of income-increasing earnings management, significant at the 0.01 level in the second last year of the earnings string period for the first (but not the second or third) earnings string sample. Finally, the coefficient estimates for PREBREAK3 and BEGSTRING are positive and significant at the 0.01 level for the first earnings string sample, but the results do not extend to the second (or third) earnings string samples. 
I interpret the results of this sensitivity analysis as consistent with prior research that suggests profit firms exhibit more income-increasing earnings management than loss firms. Firms in the first earnings string sample appear to engage in income-increasing earnings management throughout their earnings string periods. On the other hand, the coefficient estimates for PREBREAK3 and BEGSTRING in the first earnings string sample are consistently below 1 percent, suggesting that the level of income-increasing earnings management, on average, is small. 


\section{Summary and Conclusion}

This paper analyzes the earnings management behaviors of firms that report a series of at least three consecutive annual earnings increases. I focus particularly on the earnings management behavior of firms near the end of their earnings strings. I find that managers of these firms, on average, engage in income-increasing earnings management to delay the bad news of breaking an earnings string pattern. Specifically, I find consistent evidence of incomeincreasing earnings management in the last year of the earnings string period, and mixed evidence that the income-increasing earnings management started as early as two years before the break in the earnings string patterns. When I extend my earnings management tests to earnings string firms that reinitiate a new series of at least three years of consecutive annual earnings increases, I find that managers exhibit recurring tendencies to bias earnings upward when faced with the possibility of declining earnings. This result also extends to firms that report a third earnings string.

The second part of my paper examines why managers do not stretch their earnings strings even further. Based on previous research by Barton and Simko (2002), I hypothesize that managers of these firms might have run out of accounting flexibility to manage earnings upwards at the end of their earnings string periods. I use both the ratio of net operating assets to sales (NOA ratio) and the ratio of working capital net operating assets to sales (WCNOA ratio) as empirical measures of accounting flexibility (i.e., the accounting slack to manage earnings upwards). Specifically, a finding that the likelihood of breaking an earnings string is higher for 
firms with higher NOA (WCNOA) ratios suggests that managers are constrained by the amount of earnings management they can potentially engage in.

Contrary to my predictions, I do not find evidence that the likelihood of breaking an earnings string is positively associated with higher NOA ratios. However, among earnings string firms that have either repeatedly engaged in income-increasing earnings management throughout the earnings string period or have boosted earnings in the last year of their earnings string, my analysis shows that these firms are constrained by the accounting flexibility in their working capital net operating assets. This finding is consistent with results that these firms rely on income-increasing earnings management in previous years to extend their earnings string patterns. Thus, the results suggest that the break in their earnings strings for these firms is partially attributable to a lack of accounting flexibility, that prevents their managers from continuing to manage earnings upwards in the year of the earnings string break. 


\section{Appendix: Variable Definitions}

\begin{tabular}{|c|c|}
\hline Two-year BV growth rate & $\begin{array}{l}\text { Annualized growth rate of book value of equity (Compustat } \\
\# 60 \text { ) over the last two years. }\end{array}$ \\
\hline Two-year sales growth rate & $\begin{array}{l}\text { Firm's annualized growth rate of total sales (Compustat \#12) } \\
\text { over the last two years. }\end{array}$ \\
\hline Price-earnings ratio $(\mathrm{P} / \mathrm{E})$ & $\begin{array}{l}\text { Ratio of stock price at the end of the fiscal year } t \text { divided by } \\
\text { earnings per share in year } t \text { (Compustat \#199/Compustat } \\
\# 58 \text { ). }\end{array}$ \\
\hline Market-to-book ratio (M/B) & $\begin{array}{l}\text { Ratio of market capitalization (Compustat } \# 199 \times \# 25 \text { ) at the } \\
\text { end of fiscal year } t \text { divided by book value of equity } \\
\text { (Compustat \#60) in year } t\end{array}$ \\
\hline EVAR & Variance of past four years' percentage change in EPS \\
\hline STRING & $\begin{array}{l}\text { Indicator variable }=1 \text { if the firm has at least three } \\
\text { consecutive years of increasing earnings, and } 0 \text { otherwise }\end{array}$ \\
\hline BREAK & $\begin{array}{l}\text { Indicator variable }=1 \text { if the firm breaks its earnings string } \\
\text { pattern (i.e. stop reporting an annual earnings increase after } \\
\text { at least three consecutive years of earnings increases), and } 0 \\
\text { otherwise }\end{array}$ \\
\hline Discretionary accruals (DA) & $\begin{array}{l}\text { Computed using the cross-sectional variation of the } \\
\text { modified Jones model. }\end{array}$ \\
\hline $\begin{array}{l}\text { Performance adjusted } \\
\text { discretionary accruals }\end{array}$ & $\begin{array}{l}\text { Computed by controlling for ROA in the first stage of the } \\
\text { modified Jones model based on Kothari, Leone and Wasley } \\
\text { (2005). }\end{array}$ \\
\hline $\begin{array}{l}\text { Performance matched } \\
\text { discretionary accruals }\end{array}$ & $\begin{array}{l}\text { Computed by subtracting the discretionary accrual of the } \\
\text { closest non-earnings string firm matched on ROA, industry } \\
\text { and fiscal year from the earnings string firm's discretionary } \\
\text { accrual. }\end{array}$ \\
\hline
\end{tabular}




\begin{tabular}{|c|c|}
\hline $\begin{array}{l}\text { Discretionary accruals per } \\
\text { share }\end{array}$ & $\begin{array}{l}\text { Computed by converting the firm's modified Jones model's } \\
\text { discretionary accruals to a per share basis }\end{array}$ \\
\hline NOA ratio & Net operating assets divided by sales \\
\hline WCNOA ratio & $\begin{array}{l}\text { Sum of current assets and current debt less cash and current } \\
\text { liabilities, divided by sales }\end{array}$ \\
\hline Industry adjusted NOA ratio & $\begin{array}{l}\text { Calculated by subtracting the industry's median NOA ratio } \\
\text { from the firm's NOA }\end{array}$ \\
\hline $\begin{array}{l}\text { Industry adjusted WCNOA } \\
\text { ratio }\end{array}$ & $\begin{array}{l}\text { Calculated by subtracting the industry's median WCNOA } \\
\text { ratio from the firm's WCNOA ratio }\end{array}$ \\
\hline SIZE & Natural logarthim of the firm's total assets \\
\hline LEVERAGE & $\begin{array}{l}\text { Ratio of total debt (Compustat \#34+\#9) to total assets } \\
\text { (Compustat \#6) }\end{array}$ \\
\hline GROWTH & $\begin{array}{l}\text { Natural logarthim of the firm's two-year growth rate of book } \\
\text { value of equity }\end{array}$ \\
\hline FIRM AGE & $\begin{array}{l}\text { Natural logarthim of the firm's age based on the number of } \\
\text { years it appears in the Compustat database }\end{array}$ \\
\hline PREBREAK $n$ & $\begin{array}{l}\text { Indicator variable denoting } 1 \text { if the firm is } n \text { years from the } \\
\text { end of its earnings string and } 0 \text { otherwise }\end{array}$ \\
\hline BEGSTRING & $\begin{array}{l}\text { Indicator variable denoting } 1 \text { if the earnings string firm is } \\
\text { more than three years away from the end of its earnings } \\
\text { string and } 0 \text { otherwise }\end{array}$ \\
\hline TREND & $\begin{array}{l}\text { Measured in event-time as how close the firm-year } \\
\text { observations are from the end of the earnings string period. }\end{array}$ \\
\hline High EM firms & $\begin{array}{l}\text { Firms that engage in income-increasing earnings } \\
\text { management (measured using discretionary accruals) at } \\
\text { least half the years in their earnings string period }\end{array}$ \\
\hline
\end{tabular}




\begin{tabular}{|l|l|}
\hline Low EM firms & $\begin{array}{l}\text { Firms that engage in income-increasing earnings } \\
\text { management (measured using discretionary accruals) less } \\
\text { than half the years in their earnings string period. }\end{array}$ \\
\hline Pre-managed EPS & Reported EPS - Discretionary accruals per share \\
\hline LT analyst forecast dispersion & $\begin{array}{l}\text { Standard deviation of analysts' forecasts of the firm's long } \\
\text { term growth rate }\end{array}$ \\
\hline $\begin{array}{l}\text { One-year ahead analyst } \\
\text { forecast dispersion }\end{array}$ & Standard deviation of analysts' forecast of next year EPS. \\
\hline Variability of annual sales & $\begin{array}{l}\text { Standard deviation of annual sales per share over the last } \\
\text { three years }\end{array}$ \\
\hline Variability of quarterly sales & $\begin{array}{l}\text { Standard deviation of quarterly differences in sales per share } \\
\text { during the fiscal year }\end{array}$ \\
\hline
\end{tabular}




\section{References}

Ayers, B. C., X. Jiang, P. E. and Yeung. 2006. Discretionary accruals and earnings management: An analysis of pseudo earnings targets. The Accounting Review 81: 617-652.

Baker, T., D. Collins and A. Reitenga. 2003. Stock option compensation and earnings management incentives. Journal of Accounting, Auditing and Finance 18: 557-582.

Barth, M., J. Elliott and M. Finn. 1999. Market rewards associated with patterns of increasing earnings. Journal of Accounting Research 37: 387-413.

Barton, J. and P. J. Simko. 2002. The balance sheet as an earnings management constraint. The Accounting Review 77: 1-27.

Bartov, E., D. Givoly and C. Hayn. 2002. The rewards to meeting or beating earnings expectations. Journal of Accounting and Economics 33: 173-204.

Bartov, E. and P. Mohanram. 2004. Private information, earnings manipulations, and executive stock-option exercises. The Accounting Review 79: 889-920.

Ben-David, I., J. R. Graham and C. R. Harvey. 2007. Managerial overconfidence and corporate policies. Working paper. University of Chicago and Duke University.

Benish, M. D., E. Press and M. E. Vargus. 2004. Insider trading and incentives to manage earnings. Working paper. Indiana University, Temple University and University of Texas at Dallas.

Bergstresser, D. and T. Philippon. 2006. CEO incentives and earnings management. Journal of Financial Economics 80: 511-529.

Burgstahler, D. and I. Dichev. 1997. Earnings management to avoid earnings decreases and losses. Journal of Accounting and Economics 24: 99-126.

Burns, N. and S. Kedia. 2006. The impact of performance-based compensation on misreporting. Journal of Financial Economics 79: 35-67

Cheng, Q and T. D. Warfield. 2005. Equity incentives and earnings management. The Accounting Review 80: 441-476. 
Cheng, M., K. R. Subramanyam and Y. Zhang. 2007. Earnings guidance and managerial myopia. Working paper. University of Arizona, University of Southern California and Columbia University.

Coughlan, A. T. and R. M. Schmidt. 1985. Executive compensation, management turnover, and firm performance: an empirical investigation. Journal of Accounting and Economics 7: 43-66.

DeAngelo, H. L. DeAngelo and D. Skinner. 1996. Reversal of fortune. Dividend signaling and the disappearance of sustained earnings growth. Journal of Financial Economics 40: 341-371.

Dechow, P. M., S. A. Richardson and I. Tuna. 2000. Are benchmark beaters doing anything wrong? Working paper. University of Michigan.

Dechow, P. M., S. A. Richardson and I. Tuna. 2003. Why are earnings kinky? An examination of the earnings management explanation. Review of Accounting Studies 8: 355-384.

Dechow, P. M. and D. Skinner. 2000. Earnings management: Reconciling the views of accounting academics, practitioners, and regulators. Accounting Horizons 14: 235-250.

Dechow, P. M., R. G. Sloan and A. P. Sweeney. 1995. Detecting earnings management. The Accounting Review 70: 193-225.

DeFond, M. L. and J. Jiambalvo. 1994. Debt covenant violation and manipulation of accruals. Journal of Accounting and Economics 17: 145-176.

Degeorge, F., J. Patel and R. Zeckhauser. 1999. Earnings management to exceed thresholds. Journal of Business 72: 1-33.

Dickinson, V. 2006. Future profitability and the role of firm life cycle. Working paper. University of Florida.

Dikolli, S. S., W. J. Mayew and D. J. Nanda. 2008. Earnings surprises and uncertain managerial ability: evidence from CEO turnovers. Working paper. Duke University.

Durtschi, C., and P. Easton. 2005. Earnings management? The shapes of the frequency distributions of earnings metrics are not evidence ipso facto. Journal of Accounting Research 43: 557-592.

Ecker, F., J. Francis, I. Kim, P. Olsson and K. Schipper. 2006. A returns-based representation of earnings quality. The Accounting Review 81: 749-780. 
Einhorn, H. and R. Hogarth. 1978. Confidence in judgment: persistence in the illusion of validity. Psychological Review 85: 395-416.

Erickson, M. and S. Wang. 1999. Earnings management by acquiring firms in stock for stock mergers. Journal of Accounting and Economics 27: 149-176.

Ettredge, M., S. Scholz, K. R. Smith and L. Sun. 2007. The association between misstatements and bloated balance sheets. Working paper. University of Kansas and Rutgers University.

Farrell, K. A. and D. A. Whidbee. Impact of firm performance expectations on CEO turnover and replacement decisions. Journal of Accounting and Economics 36: 165-196.

Francis, J., R. LaFond, P. Olsson and K. Schipper. 2003. Earnings quality and the pricing effects of earnings patterns. Working paper. Duke University, University of Wisconsin and Financial Accounting Standards Board.

Ghosh, A., Z. Gu and P. C. Jain. 2005. Sustained earnings and revenue growth, earnings quality, and earnings response coefficients. Review of Accounting Studies 10: 33-57.

Graham, J. R., C. R. Harvey and S. Rajgopal. 2005. The economic implications of corporate financial reporting. Journal of Accounting and Economics 40: 3-73.

Guay, W. R., S. P. Kothari and R. L. Watts. 1996. A market-based evaluation of discretionary accrual models. Journal of Accounting Research 34: 83-105.

Guenther, D. 1994. Earnings management in response to corporate tax rate changes: evidence from the 1986 tax reform act. The Accounting Review 69: 230-243.

Hall, B. and J. Liebman. 1998. Are CEOs really paid like bureaucrats? Quarterly Journal of Economics 113: 653-691.

Heath, C. and A. Tversky. 1991. Preferences and beliefs: ambiguity and competence in choice under uncertainty. Journal of Risk and Uncertainty 4: 5-28.

Hirshleifer, D., K. Hou, S. H. Teoh and Y.Zhang. 2004. Do investors overvalue firms with bloated balance sheets? Journal of Accounting and Economics 38: 297-331.

Hribar, P., N. T. Jenkins and W. B. Johnson. 2006. Stock repurchases as an earnings management device. Journal of Accounting and Economics 41: 3-27.

Jensen, M. C. 2005. Agency costs of overvalued equity. Financial Management 34: 5-19. 
Jones, J. 1991. Earnings management during import relief investigations. Journal of Accounting Research 29: 193-228.

Kahneman, D., P. Slovic and A. Tversky. 1982. Judgment under uncertainty: heuristics and biases. Cambridge University Press.

Kasznik, R. 1999. On the association between voluntary disclosure and earnings management. Journal of Accounting Research 37: 57-81.

Kasznik, R. and B. Lev. 1995. To warn or not to warn: management disclosures in the face of an earnings surprise. The Accounting Review 70: 113-134.

Kasznik, R. and M. McNichols. 2002. Does meeting earnings expectations matter? Evidence from analyst forecast revisions and share prices. Journal of Accounting Research 40: 727-759.

Ke, B., S. Huddart and K. Petroni. 2003. What insiders know about future earnings and how they use it: Evidence from insider trades. Journal of Accounting and Economics 35: 315-346.

Ke, B. and K. Petroni. 2004. How informed are actively trading institutional investors? Evidence from their trading behavior before a break in a string of consecutive earnings increases. Journal of Accounting Research 42: 895-927.

Kothari, S. P., A. J. Leone and C. E. Wasley. 2005. Performance matched discretionary accrual measures. Journal of Accounting and Economics 39: 163-197.

Kothari, S. P., S. Shu and P. Wysocki. 2007. Do managers withhold bad news? Working paper. MIT and Boston College.

Lee, C. J., L. Y. Li and H. Yue. 2006. Performance, growth and earnings management. Review of Accounting Studies 11: 305-334.

Levitt, A. 1998. The "numbers game". Speech given by the Chairman of Securities and Exchange Commission. Delivered at the NYU Center for Law and Business on September 28, 1998.

Malmendier, U. and G. Tate. 2005. CEO overconfidence and corporate investment. Journal of Finance 60: 2661-2700.

Matsumoto, D.A. 2002. Management's incentives to avoid negative earnings surprises. The Accounting Review 77: 483-514.

McAnally, M. L., A. Srivastava and C. D. Weaver. 2008. Executive stock options, missed earnings targets, and earnings management. The Accounting Review 83: 185-216. 
McVay, S., V. Nagar and V. Tang. 2005. Trading incentives to meet earnings thresholds. Working paper. New York University and University of Michigan.

Mehran, H. 1995. Executive compensation structure, ownership and firm performance. Journal of Financial Economics 38: 163-184.

Murphy, K., and J. L. Zimmerman. 1993. Financial performance surrounding CEO turnover. Journal of Accounting and Economics 16: 273-315.

Myers, J., L. Myers and D. Skinner. 2007. Earnings momentum and earnings management. Journal of Accounting, Auditing and Finance 22: 249-284.

Nissim, D., and S. H. Penman. 2001. Ratio analysis and equity valuation: From research to practice. Review of Accounting Studies 6: 109-154.

Palmrose, Z. and S. Scholz. 2004. The circumstances and legal consequences of non-GAAP reporting: Evidence from restatements. Contemporary Accounting Research 21: 139-180.

Palmrose, Z., V. J. Richardson and S. Scholz. 2004. Determinants of market reactions to restatement announcements. Journal of Accounting and Economics 37: 59-89.

Penman, S. H. 1996. The articulation of price-earnings ratios and market-to-book ratios and the evaluation of growth. Journal of Accounting Research 34: 235-259.

Penman, S. H. 2003. The quality of financial statements: Perspectives from the recent stock market bubble. Accounting Horizons 17: 77-96.

Rao, R. 1997. Learn to play the earnings game (and Wall Street will love you). The pressure to report smooth, ever higher earnings has never been fiercer. Fortune.

Richardson, S., S. H. Teoh and P. D. Wysocki. 2004. The walk-down to beatable analyst forecasts: the role of equity issuance and insider trading incentives. Contemporary Accounting Research 21: 885-924.

Sawicki, J. and K. Shrestha. 2008. Insider trading and earnings management. Journal of Business Finance and Accounting forthcoming.

Schipper, K. 1989. Commentary on earnings management. Accounting Horizons 3: 91-102.

Skinner, D. 1994. Why firms voluntarily disclose bad news? Journal of Accounting Research 32: 3861. 
Skinner, D. and R. Sloan. 2002. Earnings surprises, growth expectations, and stock returns or don't let an earnings torpedo sink your portfolio. Review of Accounting Studies 7: 289-312.

Smith, K. R. 2004. Earnings management constraints and market reactions to subsequent earnings surprises. Working paper. University of Arizona.

Stein., J. C. 1988. Efficient capital markets, inefficient firms: a model of myopic corporate behavior. The Quarterly Journal of Economics 104: 655-669.

Subramanyam, K. R. 1996. The pricing of discretionary accruals. Journal of Accounting and Economics 22: 249-281.

Teoh, S. H., I. Welch and T. Wong. 1998a. Earnings management and the long-run market performance of initial public offerings. Journal of Finance 53: 1935-1974.

Teoh, S. H, I. Welch and T. Wong. 1998b. Earnings management and the underperformance of seasoned equity offerings. Journal of Financial Economics 50: 63-99.

Teoh, S. H., I. T. Wong and G. R. Rao. 1998. Are accruals during initial public offerings opportunistic? Review of Accounting Studies 3: 175-208.

Warner, J. B., Watts, R. L. and K. Wruck. 1988. Stock prices and top management changes. Journal of Financial Economics 20: 461-492.

Watts, R. L. and J. L. Zimmerman. 1990. Positive accounting theory: A ten year perspective. The Accounting Review 65: 131-156.

Weisbach, M.S. 1988. Outside directors and CEO turnover. Journal of Financial Economics 20: 431460.

Xie, H. 2001. The mispricing of abnormal accruals. The Accounting Review 76: 357-373. 


\section{Biography}

Kevin Ow Yong was born in Singapore on November 17, 1975. He earned his Bachelor of Accountancy (First Class) in 1999 from Nanyang Technological University. He became a Chartered Financial Analyst in 2002 and a Certified Public Accountant (Singapore) in 2003. He was admitted to the Ph.D. program in Business Administration (Accounting) at the Fuqua School of Business, Duke University in 2003. 